\title{
ESTABILIDADE A LONGO PRAZO \\ DO TRATAMENTO DA MORDIDA ABERTA, COM EXTRAÇÕES, NA DENTADURA PERMANENTE
}

\author{
REJANE TARGINO SOARES BELTRÃO
}

Dissertação apresentada à Faculdade de Odontologia de Bauru, da Universidade de São Paulo, como parte dos requisitos para obtenção do título de Mestre em Odontologia, área de Ortodontia

(Edição revisada)

Bauru

2002 


\section{ESTABILIDADE A LONGO PRAZO DO}

\section{TRATAMENTO DA MORDIDA ABERTA, COM EXTRAÇÕES, NA DENTADURA}

PERMANENTE

REJANE TARGINO SOARES BELTRÃO

Dissertação apresentada à Faculdade de Odontologia de Bauru, da Universidade de São Paulo, como parte dos requisitos para obtenção do título de Mestre em Odontologia, área de Ortodontia Orientador: Prof. Dr. Marcos Roberto de Freitas

(Edição revisada)

Bauru

2002 
Beltrão, Rejane Targino Soares

B419e Estabilidade a longo prazo do tratamento da mordida aberta, com extrações, na dentadura permanente / Rejane Targino Soares Beltrão - Bauru, 2002

153p. + apêndices; $29,7 \mathrm{~cm}$

Dissertação (Mestrado) _ Faculdade de Odontologia de Bauru, USP.

Orientador: Prof. Dr. Marcos Roberto de Freitas

Autorizo, exclusivamente para fins acadêmicos e científicos, a
reprodução total ou parcial desta dissertação, por processos fotocopiadores
e/ou meios eletrônicos.
Assinatura do autor. Rejane Targino Soares Beltrão
Data: $04 / 04 / 2002$




\section{REJANE TARGINO SOARES BELTRÃO}

19 de Novembro de 1970

João Pessoa-Pb

Nascimento

$1990-1995$

Curso de Odontologia na

Universidade Federal da

Paraíba.

$1996-1997$

Curso de Aperfeiçoamento em Ortodontia pela ACOPEN (Assessoria e Consultoria de Ortodontia, Pesquisa e Ensino, em Bauru-SP.

$1997-1999$

Curso de Especialização em Ortodontia e Ortopedia Facial, pela Associação Paulista de Cirurgiões Dentistas Regional Bauru

$2000-2002$

Curso de Pós-graduação em Ortodontia, ao nível de Mestrado, na Faculdade de Odontologia de Bauru da Universidade de São Paulo.

Associação

Associação Brasileira de Odontologia - Seção Paraíba 


\section{Dedicatária}

A Oeres, pela milagie de estar viva, alcancando a guaca deste ideal tâa almejado por mim;

Llos meus pais, foũa (in memoriam) e Lauluce, responsáveis pela formação do meu carater e intelectual, oferecendo-me a methor de suas vidas;

So meu esposo, Pricaudo, que com seu apoia e carinho incondicional, sempre me entusiasmou e me molivou. $\mathscr{E}$, juntamente com minha filha Priscila, renunciaram ass seus sonhos, para que muitas veres pudesse realisar as meus, compreendendo sempie as minhas ausências, estando com sovisos nos lailicis a cada encontra;

Slos meus sogras Clóvis o Oaisy que, por muitos anos, compartitharam, wo meu lado, Lodas as minhas preocupacoies e ansiedades, na busca incessante deste ideal, compreendenda-me e apoianda-me sempie nas hovas mais dificeis, e pela dedicasâa à Priscila por Lodos esises anos

Com amor, dedica este tuabutho. 


\section{Agradecimentos Ëspeciais}

Al todos as meus familiares que sempre me trataram com carinho e atencião e que souberam compicender a minha ausência.

As grandes amigas o companhivas Lovena e Helena, que convivexam diaviamente comiga, compartilhando das minhas alegiass o bisteras o estimulanda-me sempie nos momentas de fraquera, durante tada esse tempo do mestrado.

As guandes amigas Striana, Daniele, Fomanda o Sandua, que compartilhauam comiga as momentos de alegia o bistera, estando sempre ao meu lado nos momentos mais dificeis.

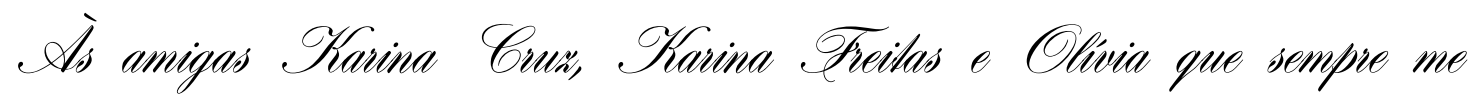
ajudaram de forma sincera e despietenciasa, nos momentas que as procurei:

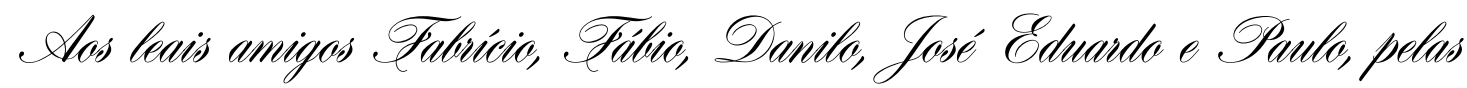
suas amizades despretenciosas o incondicionais, me apoiando sempre nos momentos em que os procurei:

Deseja a Lados muita sucesso acompanhado de muita pas e saúde 
Agradecimenta Especial

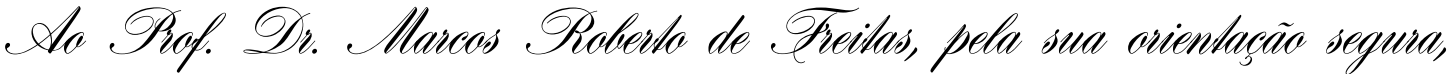

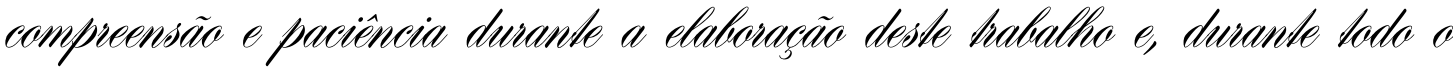
mesthado, como tambím pela confianca em mim depositada, opostunidade do convivio e enviquecimento profissional e pessoal.

Ninha sincera gualidãa!!!! 


\section{Agradecimento Ëspecial}

A. Rop. Or. Guilherme dos Reis Peveiva Zanson por privilegiar-nos com seus ensinamentos e pelo seu exemplo de puofesson e seviedude do seu trabuatho.

Heu sincero agradecimento. 


\section{Mer Prafunda Alfeto}

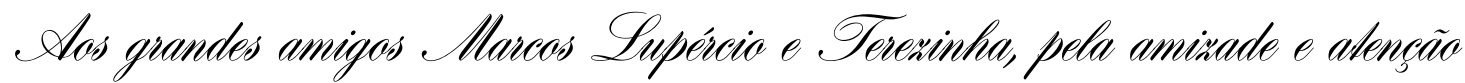
que sempre demonsharam, sem que medissem esforcos para me ajudar na hove de que mais precisei:

So grande amigo Alcides que, nos momentos de bistera, deu-me alegia e covagem, ajudanda-me, muitas veres sacrificando seus hovários de descanso.

Slos grandes amigos Daniel o Olivia, pelas suas presencas amigas o despretenciosas, sempie nos momentas que as solicitei:

Stas amigas Yilor a Paula, que consideva coma anjos protetores, pela amirade e prestera que sempre dispensaram a mim.

Stos grandes amigas mineivas Ana Paula, Gosé Alfreda, Guistina, Tran, Lincon a Gélia, que foum para mim exemplos do coragem, determinacão o solidariedade, honiando-me com suas amizades

So guande amiga Felipe Foves pela sua dedicacãa nos mous pacientes duxante todo a meshado, agindo sempie com muita ética e sinceridade.

Sâ tendo para essas pessoas, palaveas para aguadecer Lanta doacaio, peco a Fous que os proteja, velubiunda-lhes em dobua Ludo a que fireram por mim. 
Agradecimentas

Stos professores da disciplina de Ortadontia, do Departamenta de

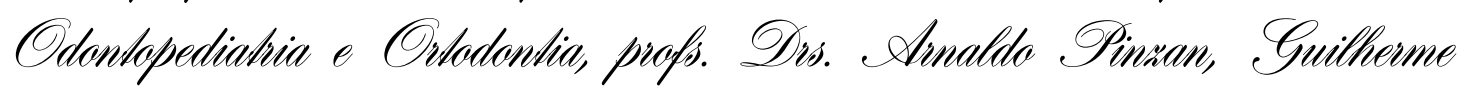

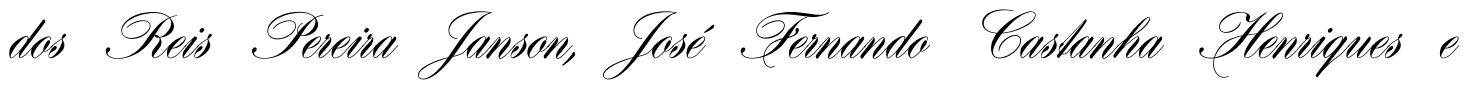
Renata Radiigues de Almeida.

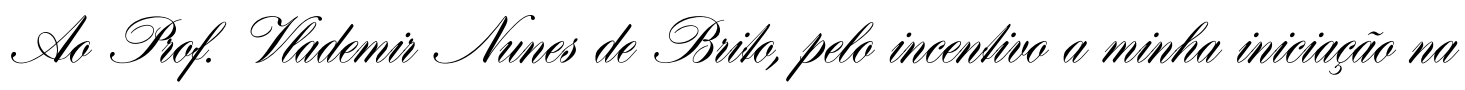
cavicia docente e pela confianca em mim depositada.

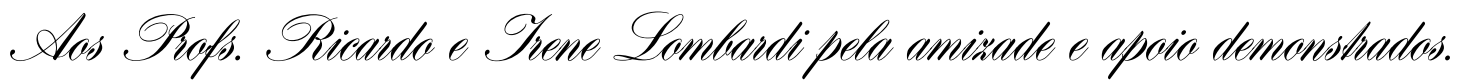

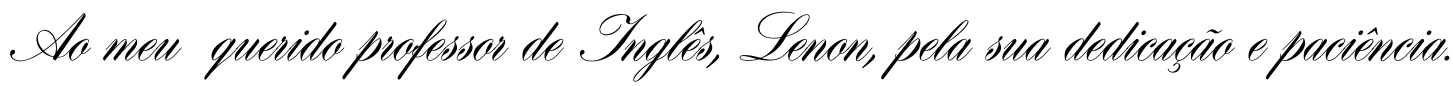

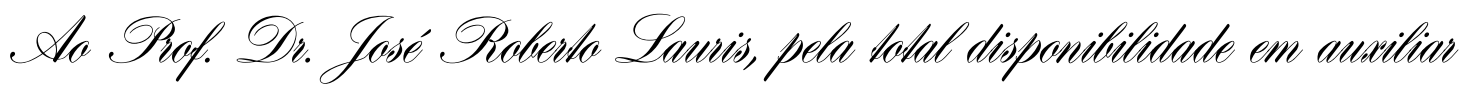
na realinacäa das análises estatisticas.

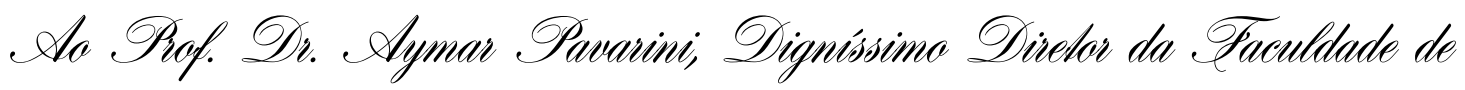
Odontologia de Baum, da Olniversidude do Saco Paulo.

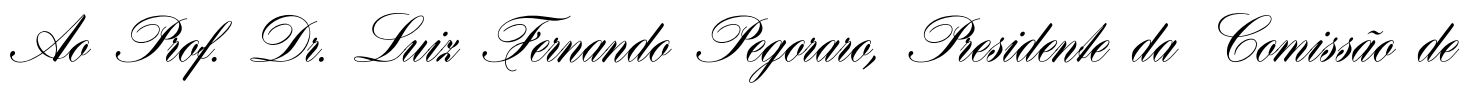
Pos-Graduaciá da Fraculdade de Odontologia de Baume, da Olnivesisidude de Sâo Paulo.

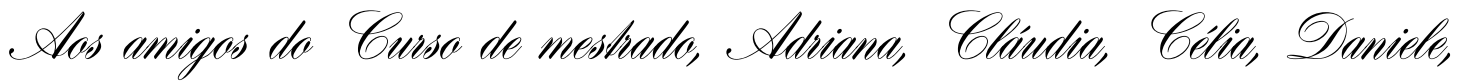

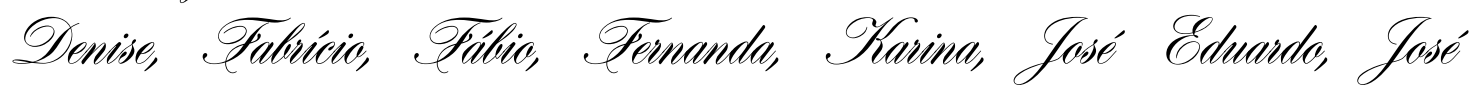

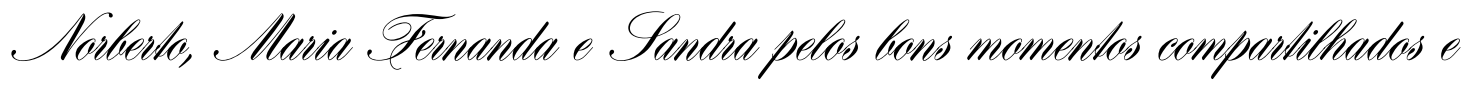
por hudo que aprendemos.

ix 


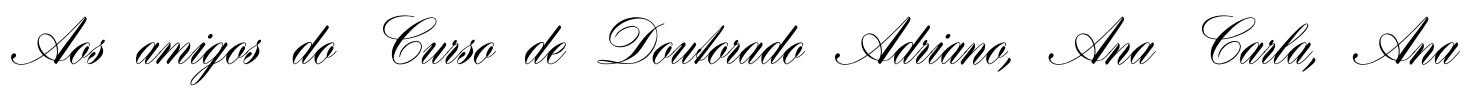
Claudia, Daniela, Danilo, Pausto, Karina Curn, Karina Yalle o Renata pela amirade sempre presente em nosiso convivio e pelos ensinamentos Luansmilidas.

Stos amigas do novo mestuado, Analu, Angela, Kaaina, Celso, Guistina,

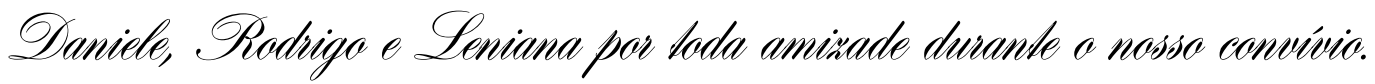

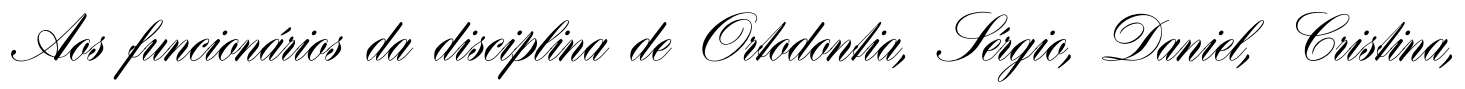

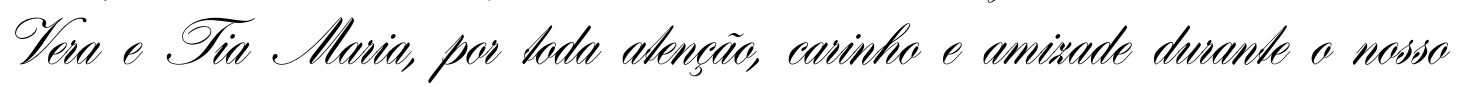
convivio.

Stos funcionávios da pós-Graduacão, pelas opostunidades o facilidades foinecidas.

Alos funcionaivios da Bibliateca, pela atencião o sevicos prestados.

Al Frundaciáa de Apoia a Pesquisa do Éstado de Saco Paula

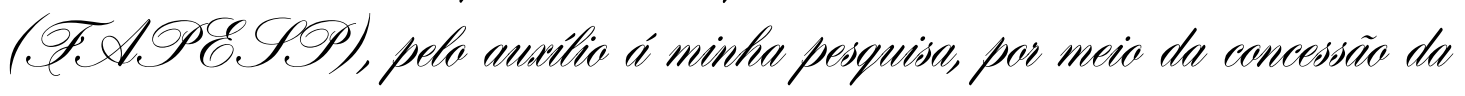
bolsa de estudas.

$\mathrm{X}$ 


\section{SUMÁRIO}

LISTA DE FIGURAS ............................................................

LISTA DE TABELAS ...................................................................

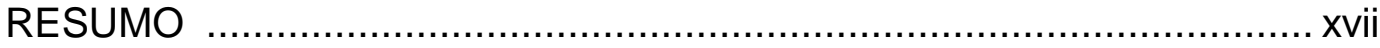

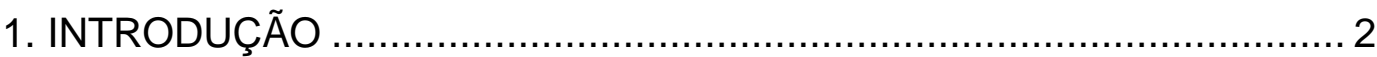

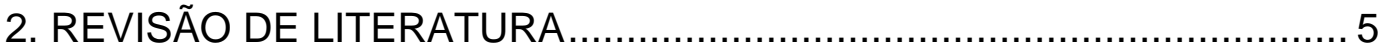

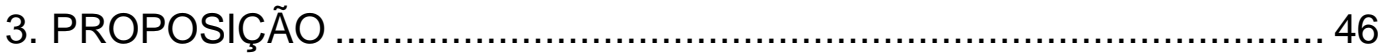

4. MATERIAL E MÉTODOS ........................................................ 48

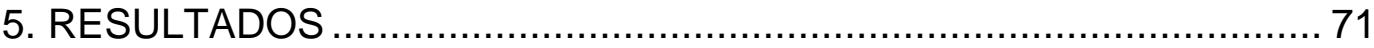

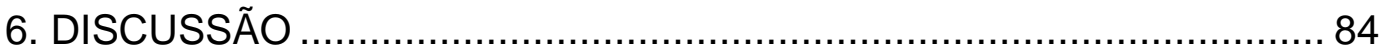

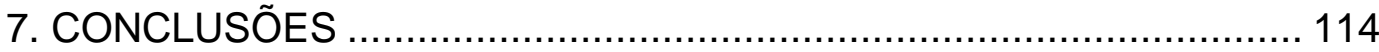

8. REFERÊNCIAS BIBLIOGRÁFICAS ......................................... 117

ABSTRACT

APÊNDICE 


\section{LISTA DE FIGURAS}

Figura 1 _ Delimitação do desenho anatômico ……………………........... 52

Figura 2 - Demarcação dos pontos cefalométricos. ................................... 55

Figura 3 - Representação das linhas e planos de referência .......................... 57

Figura 4 - Grandezas angulares esqueléticas …………………............... 59

Figura 5 - Grandezas lineares esqueléticas ............................................... 61

Figura 6 - Grandezas dentárias angulares e lineares .................................. 63

Figura 7 - Paciente da amostra, durante a fase do tratamento ortodôntico fixo, com elásticos verticais para o fechamento da mordida aberta, associado ao AEG (IHG) ..............................66

Figura 8 - Vista intrabucal frontal, durante a fase T2 e T3 …....................... 66

Figura 9 - Alteração do ângulo do plano palatino em relação à base do crânio, após o término de tratamento 92

Figura 10 - Alterações do ângulo do plano mandibular em relação à base do crânio e do plano de Francfort da fase T1 - T2

Figura 11 - Alteração do ângulo do plano mandibular em relação ao ramo mandibular, após o término de tratamento

Figura 12 - Alterações das alturas faciais ântero-inferior e anterior total, após o término de tratamento

Figura 13 - Alteração das inclinações dos incisivos superiores e inferiores

Figura 14 - Alterações das alturas dentoalveolares dos incisivos e molares entre as fases $\mathrm{T} 1$ e T2

Figura 15 - Alteração da inclinação do plano oclusal em relação à base do crânio 
Figura 16 - Alteração do trespasse vertical após o término de tratamento 98

Figura 17- Alteração do trespasse vertical cinco anos após o término de tratamento

Figura 18- Alterações do ângulo do plano mandibular em relação à base do crânio e do plano de Francfort durante a fase T2-T3 103

Figura 19- Alteração das medidas angulares SNA, SNB e ANB durante a fase T2-T3

Figura 20- Alteração do ângulo do plano palatino em relação à base do crânio, durante a fase T2-T3 104

Figura 21- Alteração da inclinação do plano oclusal em relação à base do crânio durante a fase T2-T3

Figura 22- Alteração das medidas lineares S-Go e Ar-Go durante a fase T2-T3 106

Figura 23- Alteração do ângulo do plano mandibular em relação ao ramo mandibular durante a fase T2-T3

Figura 24- Alterações das alturas faciais ântero-inferior e anterior total, durante a fase T2-T3 108

Figura 25- Alterações das medidas angulares IMPA e 1.NB, durante a fase T2-T3 109

Figura 26- Alterações das medidas lineares Bll-GoMe, 6I-GoMe, 6S-PP e BII-NB, durante a fase T2-T3. 


\section{LISTA DE TABELAS}

Tabela 1 - Comparação entre as medidas dentoesqueléticas da fase inicial (T1) e do Atlas de crescimento.

Tabela 2 - Médias e desvio padrão das medidas cefalométricas iniciais (T1) e pós tratamento (T2), bem como as diferenças estatísticas

Tabela 3 - Médias e desvio-padrão das medidas cefalométricas, póstratamento (T2) e cinco anos pós-tratamento (T3), bem como as diferenças estatísticas.

Tabela 4 - Trespasse vertical (BIS-Po) valor médio, mínimo, máximo e desvio-padrão

Tabela 5 - Teste de correlação de Pearson 79

Tabela 6 - Trespasse vertical inicial, final e cinco anos pós-tratamento, demonstrando que, após a fase T3, oito pacientes apresentaram uma recidiva clínica de $25,8 \%$

Tabela 7 - Análise estatística para confirmar a confiabilidade do método cefalométrico. Apresentação das médias e desviopadrão, para os dois tempos realizados, do teste "t" de Student e do erro casual (Dahlberg) para cada medida analisada. 
Resumo 


\section{RESUMO}

A realização deste trabalho teve como objetivo avaliar cefalometricamente a estabilidade da mordida aberta após cinco anos de tratamento, bem como a correlação deste resultado com possíveis alterações esqueléticas e dentárias. Para tanto, foram utilizadas 93 telerradiografias de 31 pacientes, constituindo um único grupo tratado, avaliado em três fases, inicial (T1), final (T2) e no mínimo, cinco anos pós-tratamento (T3). Todos os pacientes apresentaram inicialmente uma mordida aberta anterior maior que $1 \mathrm{~mm}$, quando medidos em modelos de estudo, com má oclusão de Classe I e II, em fase de dentadura permanente e que foram tratados ortodonticamente com aparelhos fixos, pela técnica "edgewise", com extrações. Estes pacientes foram selecionados do arquivo da Disciplina de Ortodontia da Faculdade de Odontologia de Bauru - USP e ao serem comparados inicialmente com o grupo controle, apresentaram: planos palatino e mandibular divergentes; ramo mandibular diminuído; altura facial ântero-inferior aumentada; padrão de crescimento acentuadamente vertical; incisivos superiores e inferiores acentuadamente protruídos e apenas os superiores acentuadamente inclinados para vestibular

Todos os resultados foram submetidos à análise estatística, revelando que a mecânica empregada mostrou-se bastante efetiva na correção desta displasia vertical; entretanto esta correção ocorreu mais em conseqüência de alterações dentárias do que esqueléticas, e após no mínimo, cinco anos de tratamento apresentou uma estabilidade clínica de 74,2\%. As grandezas esqueléticas e dentárias demonstraram alterações estatisticamente significantes que corroboraram para esta estabilidade, e, após a correlação do trespasse vertical verificado, durante a fase controle, com o trespasse vertical inicial (T1) e final (T2), concluiu-se que quanto maior a mordida aberta inicial, maior a alteração do trespasse vertical na fase T3, e quanto maior o trespasse vertical obtido após o tratamento, menor a alteração deste trespasse na fase T3. 
1. Introdução 


\section{INTRODUÇÃO}

A mordida aberta anterior pode ser definida como a presença de um trespasse vertical negativo existente entre as bordas incisais dos dentes ântero-superiores e inferiores, consistindo em uma discrepância no sentido vertical, o que a torna mais difícil de ser corrigida, e seus resultados finais mostram-se pouco estáveis, variando de acordo com a sua gravidade, etiologia e fase em que foi tratada. ${ }^{5,41,94}$

De um modo geral, as mordidas abertas anteriores podem ser classificadas em: dentárias, dentoalveolares e esqueléticas, conforme as estruturas envolvidas na má oclusão. ${ }^{6,41,102}$

Essa má oclusão acarreta alterações no aspecto estético do indivíduo, dificulta a apreensão e corte dos alimentos, prejudicando também os fonemas, podendo ainda levar o indivíduo a situações desagradáveis em seu ambiente social, criando para ele condições psicológicas desfavoráveis, ${ }^{18}$ pois esse tipo de má oclusão apresenta um certo grau de desconforto. Então, essa deve ser corrigida precocemente, até mesmo porque quanto mais precoce mais simples será sua terapêutica e melhor seu prognóstico. ${ }^{46,52,55}$

Dentre os procedimentos utilizados para correção das mordidas abertas anteriores de natureza dentária e dentoalveolar com relação oclusal normal, causadas pelos hábitos deletérios, o mais difundido é a utilização da grade palatina. Esse aparelho pode ser fixo ou removível, dependendo do grau de colaboração do paciente. Porém, nem sempre o tratamento é feito na fase ideal, durante a dentadura mista, e, quando se apresenta na fase de dentadura permanente, geralmente há o envolvimento de componentes esqueléticos na sua composição, empregando-se muitas vezes, o tratamento corretivo com extrações, mas quando há um acentuado comprometimento esquelético, então deve-se associar ao tratamento cirúrgico.

Nenhum trabalho na literatura se refere exatamente à estabilidade da mordida aberta, dos casos tratados apenas com extrações, e os que se 
referem à estabilidade pós-tratamento da mordida aberta, demonstram poucos anos de controle após o tratamento ou uma amostra muito pequena ${ }^{37,55,59,63,72,74}$. Por essa razão, a presente pesquisa tem o objetivo de avaliar a estabilidade da correção da mordida aberta anterior, dos casos tratados na fase da dentadura permanente, com extrações, após cinco anos do término de tratamento e sua correlação com alterações dentárias e ou esqueléticas. Como também, caracterizar cefalometricamente os pacientes com mordida aberta comparando com um grupo controle, obtido do Atlas de Crescimento Craniofacial da Faculdade de Odontologia de Bauru-USP. 
2. Revisão de

Literatura 


\section{REVISÃO DE LITERATURA}

\section{1- Características gerais e cefalométricas}

Para definir essa má oclusão, SUBTELNY ${ }^{145}$, em 1964 e WORMS ${ }^{155}$, em 1971, consideraram-na como um desvio na relação dos arcos dentários maxilares e mandibulares, apresentando uma visível falta de contato no sentido vertical, entre os seguimentos opostos dos dentes, correlacionando-o ao crescimento vertical da face. Já, BJÖRK ${ }^{18}$, em 1969, definiu como a ausência de uma região localizada da oclusão, enquanto que os dentes restantes encontram-se em oclusão. Outra definição foi relatada por VAN DER LINDER $^{150}$, em 1986, e MOYERS ${ }^{93}$, em 1991, como sendo uma deficiência no contato vertical normal entre os dentes antagonistas, podendo manifestar-se em uma região limitada ou, mais raramente, em todo o arco dentário.

Para classificá-la muitos autores basearam-se quanto à extensão, amplitude, severidade, fatores etiológicos e a região afetada, como: WORMS et al. ${ }^{155}$, em 1971, classificaram-na quanto à sua extensão em: 1) simples, quando ocorre de canino a canino; 2) composta, de pré-molar a pré-molar e 3) infantil, quando atinge os molares; DAWSON ${ }^{33}$, em 1974, classificou a amplitude ou o grau de separação entre os dentes anteriores, baseando-se na amplitude de abertura, em: 1) mínima, uma abertura de 1mm;2) moderada, uma abertura de 1 a $5 \mathrm{~mm}$ e 3) severa, uma abertura superior a $5 \mathrm{~mm}$; NAHOUM $^{95}$, em 1975, propôs uma forma bem objetiva, dividindo-a em duas categorias: 1) dentária, sem displasia craniofacial, e, 2) esquelética, que segundo BARRER ${ }^{13}$, em 1964, é mais difícil de ser tratada, apresentando uma correção limitada, devido o padrão de crescimento ser o fator etiológico principal; RICHARDSON ${ }^{124}$, em 1981, propôs uma classificação quanto aos seus fatores etiológicos em: 1) transitórias, devido à falta de desenvolvimento dentoalveolar; 2) as causadas por hábitos; 3) por patologias locais (dentes suprapumerários, cistos e dilacerações); 4) por patologias gerais com 
alterações esqueléticas (fissuras palatinas e disostoses craniofaciais); 5) pelo padrão de crescimento vertical não patológico; e 6) as causadas pela morfologia e comportamento da língua e lábios; Já ALMEIDA; URSI ${ }^{6}$, em 1990, classificaram em: 1) dentária, resultante da obstrução da irrupção normal dos dentes anteriores, sem o envolvimento do processo alveolar; 2) dentoalveolares, quando existe um comprometimento do desenvolvimento ósseo a nível alveolar; e 3) esqueléticas, quando as alterações vão além dos componentes dentoalveolares, atingindo também as estruturas ósseas faciais; Enquanto, MOYERS ${ }^{92}$, em 1991, classificou-a em: 1)simples, quando esta localiza-se apenas na região dentária e no processo alveolar e 2)Complexas, quando apresentam displasias esqueléticas verticais.

Há muito tempo tem-se relatado a grande relação do padrão de crescimento facial vertical com a mordida aberta, como também a sua associação com outras más oclusões, e, ainda, com um crescimento deficiente da mandíbula, em uma direção para baixo e para trás, e, muitas vezes, com uma maxila mal desenvolvida ${ }^{97}$.

Uma amostra constituída de 115 pacientes com mordida aberta, dos quais 64 apresentavam-se em Classe I, 46 em Classe II e 5 em Classe III, foi estudada clinicamente por SWINEHART ${ }^{146}$, em 1942. O mesmo concluiu que, houve uma grande tendência da mordida aberta nos casos de Classe I e II , e sem significância nos casos de Classe III, mostrando ainda que, dentro de cada má oclusão, houve uma variação na região em que ocorreu. Assim, na Classe I, apresentou-se mais na região anterior, sendo $75 \%$ na região de incisivos e $16 \%$ incluindo os caninos. Na Classe II, 54\% ocorreram na região dos incisivos, $30 \%$ na região dos caninos e $16 \%$ se estenderam além dos caninos, e um caso se estendeu até os segundos molares. Observando-se ainda que, dos 115 casos, ocorreu uma variação do plano oclusal superior, apresentando-se, na maioria dos casos, infra-oclusão dos dentes superiores na região da mordida aberta, e a alteração do plano oclusal inferior foi muito menos freqüente, observando-se em 33\% na Classe I, 7\% na Classe II e nenhuma na Classe III. A inclinação vestibular dos incisivos superiores também contribui para 0 estabelecimento da mordida aberta, demonstrando que aquela ocorreu em $72 \%$ na Classe I, 52\% na Classe II e foi ausente na Classe III, sem ocorrer no 
arco inferior, observando-se que os efeitos da mordida aberta são mais vistos no arco superior do que no inferior, concluindo-se ainda que a mordida aberta pode ocorrer nos diferentes tipos de padrão facial, sem haver uma correlação estatisticamente significante pelo tipo facial.

Após um estudo em 52 crianças que apresentavam mordida aberta, HAPAK $^{59}$, em 1964, avaliou, cefalometricamente, os padrões esqueléticos e dentários, concluindo que a mordida aberta ocorre em qualquer tipo de padrão esquelético, havendo uma tendência de encontrar-se associada com a má oclusão de Classe II, mas sem se apresentar de uma forma constante.

Muitos autores 54,59,97,121,142 concluíram que a altura facial ânteroinferior é maior nos pacientes com mordida aberta do que aqueles que não possuem esse tipo de má oclusão, e alguns ${ }^{54,59}$ concordam que a altura facial superior é a mesma nos grupos-controle e nos pacientes com displasias verticais, e que a diferença ocorre somente no terço inferior da face. E, de acordo com OSBORN ${ }^{105}$, em 1983, essas alterações verticais ocorrem devido à desarmonia do crescimento vertical, e são refletidas nos ângulos Oclusomandibular e SN-oclusal, podendo ser alterado pelo crescimento vertical.

A mordida aberta esquelética pode ser descrita como um tipo básico de discrepância vertical, constituindo, assim, uma síndrome diferente da displasia dento-alveolar, como relatado por SASSOUNI ${ }^{130}$, em 1969, e WATSON ${ }^{152}$, em 1991, que a caracterizam por vários fatores, tais como: o ângulo goníaco obtuso; a altura facial posterior tende a ser a metade da altura facial anterior e esta exceder a altura facial superior. E, segundo $\mathrm{NAHOUM}^{94}$, em 1971, GILE ${ }^{55}$, em 1972 e PROFFIT ${ }^{115}$, em 1986, essas características mencionadas também podem ser características de uma displasia dentoalveolar, não se devendo diferenciar uma mordida aberta esquelética de uma dento-alveolar, de modo que essas características podem ser encontradas tanto na displasia esquelética como na dentoalveolar.

Como também ao caracterizar os pacientes com mordida aberta, BJÖRK ${ }^{18}$, em 1969, afirmou que a tendência de mordida aberta nos pacientes em crescimento, é, na maioria das vezes, sinônimo de uma mandíbula com direção de crescimento para trás, sendo difícil nesses casos, prevenir essa abertura, apresentando sete características cefalométricas relacionadas às 
rotações de crescimento significantemente anormais, como: 1) inclinação da cabeça do côndilo; 2) a curvatura do canal mandibular; 3) a forma da borda inferior da mandíbula; 4) a inclinação da sínfise; 5) o ângulo interincisal; 6) o ângulo interpremolar e intermolar; e 7) a altura facial ântero-inferior. Considerando-se mais favorável essas medidas ao invés das várias medidas cefalométricas tradicionais, que têm sido o foco da atenção na maior parte dos trabalhos de literatura sobre mordida aberta, como também os fatores biológicos que podem contribuir para a tendência da mordida aberta, como as diferenças individuais na postura da língua, o padrão de mastigação e o tipo de respiração, os quais não podem ser quantificados em uma radiografia cefalométrica.

Em estudo das variações do crescimento vertical facial, ISACSSON et al. ${ }^{64}$, em 1971, concluíram que, em padrão facial normal, o côndilo mandibular tende a crescer adequadamente para compensar a erupção dentária fisiológica; enquanto que, quando ocorre uma sobrecompensação, pode haver uma diminuição do ANB e um aprofundamento da mordida, e, quando ocorre uma falta de compensação, pode se estabelecer uma mordida aberta.

Ao contrário da discrepância esquelética, $\mathrm{NAHOUM}^{95}$, em 1975, concluiu que a mordida aberta anterior dento-alveolar relaciona-se com o padrão facial vertical equilibrado e o problema normalmente restringe-se aos arcos dentários, em especial o superior e os fatores causais giram em torno de hábitos. O mesmo autor ${ }^{95}$, em 1977, relatou que a proporção entre a altura facial ântero-superior e a altura facial ântero-inferior (AFAS/AFAI), é muito importante para predizer a severidade de um mordida aberta, considerando-se normal uma proporção de 0,8 e a média dos pacientes com má oclusão de mordida aberta 0,6 (sem incluir pacientes com retrognatismo mandibular), e que a magnitude de abertura interincisal por si só pode ser enganosa, a menos que essa medida apresente-se correlacionada com as medidas faciais e com o estágio de desenvolvimento do paciente.

Uma amostra de 32 indivíduos do gênero feminino, leucoderma, foi estudada cefalometricamente por FROST et al. ${ }^{52}$, em 1980, dos quais 19 apresentaram relação oclusal de Classe I, de Angle com boas proporções dento-alveolares, enquanto 13 demonstraram acentuada mordida aberta 
esquelética, necessitando de tratamento ortodôntico cirúrgico. As radiografias cefalométricas do grupo de mordida aberta, em pré-tratamento, foram comparadas com as do grupo-controle, analisando-se, no grupo de mordida aberta, uma distância maior do plano palatino ao ápice dos primeiros molares superiores, indicativo de um excesso vertical maxilar, concluindo que esse tipo de displasia dento-alveolar relaciona-se com a rotação da mandíbula devido à abertura da mordida, resultando em um ângulo do plano mandibular aumentado, um ângulo SNB reduzido e uma altura facial ântero-inferior aumentada.

As características morfológicas faciais verticais, de 21 jovens apresentando mordida aberta, com idade de 6 a 12 anos, e 42 adultos jovens com vários tipos faciais verticais, foi estudada por FIELDS et al. ${ }^{47}$, em 1984. Esses grupos foram examinados clinicamente divididos em três classificações: face longa, normal e curta, concluindo que, tanto nas crianças de face longa quanto nos adultos, a altura total da face anterior, o ângulo do plano mandibular, o ângulo do plano goníaco e o ângulo do plano maxilomandibular foram bem maiores do que o normal. A altura do ramo não foi significantemente diferente nos jovens, mas houve uma tendência para os adultos com face longa apresentarem ramos curtos, sendo evidente 0 excessivo desenvolvimento dento-alveolar na região posterior, dos jovens de face longa, mas não nos adultos.

Outro autor ao estudar as características cefalométricas dos pacientes com mordida aberta, foi CANGIALOSI ${ }^{22}$, em 1984, que avaliou um grupo de 60 pacientes com mordida aberta e oclusão normal de Classe I, e, 60 que não se submeteram a tratamento, observando as seguintes grandezas cefalométricas: 1) a proporção da altura facial anterior para posterior; 2) a proporção da altura facial superior para inferior; 3) o ângulo Sn.GoGn; 4) o ângulo goníaco; 5)o ângulo Sn.PP; e 6) o ângulo PP.GoGn. Concluindo que houve uma constância das proporções dos ângulos com a idade e foi feita uma tentativa para separar a amostra de mordida aberta nos grupos esquelético e dento-alveolar.. $\mathrm{Na}$ amostra de mordida aberta, comparando-se ao grupo-controle, o estudo demonstrou uma diminuição na proporção entre a altura facial posterior e anterior, uma diminuição na proporção entre a altura facial superior e inferior e 
um aumento em outros ângulos medidos. Além do mais, a divisão da amostra acima, em grupos na dentadura mista e permanente, mostrou que os ângulos e suas proporções permanecem relativamente constantes com a idade. $\mathrm{Na}$ tentativa de dividir a amostra de mordida aberta em grupos esquelético e dento-alveolar, resultou em valores maiores para todas as medidas obtidas, apresentando dificuldades na diferenciação entre os dois grupos e a variabilidade dos padrões dentoesqueléticos na mordida aberta é discutida, chegando-se às seguintes conclusões:

1) a altura facial posterior é menor e a altura facial anterior total é maior no grupo com mordida aberta;

2) a altura facial inferior é maior em relação à altura facial ânterosuperior no grupo com mordida aberta;

3) o ângulo do plano mandibular e o ângulo goníaco são maiores no grupo com mordida aberta;

4) o ângulo PP.GoGn é maior no grupo com mordida aberta e isso deve ser devido à inclinação do plano mandibular para baixo;

5) as proporções e ângulos medidos permanecem relativamente constantes, em ambos os grupos da dentadura mista para permanente, indicando que apenas o tamanho (mas não a proporção) muda com a idade;

6) as medidas no grupo com mordida aberta esquelética foram significantemente diferentes daquelas dos pacientes com mordida aberta dento-alveolar e da amostra de mordida aberta como um todo, exceto para o ângulo Sn.PP. Sendo essa má oclusão multifatorial, existindo uma variedade quase infinita de configurações dento-esqueléticas e a magnitude da displasia associada com isso.

Para identificar a freqüência e a distribuição dos componentes esqueléticos e dentários da má oclusão de Classe II, no adulto com e sem mordida aberta, ELLIS; Mc NAMARA; LAWRENCE ${ }^{41}$, em 1985, avaliaram 124 pacientes, metade dos quais possuía a mordida aberta anterior. Diferenças estatisticamente significantes entre os grupos com e sem mordida aberta foram encontradas, obtendo-se os seguintes resultados, nos casos de mordida aberta: a porção posterior da maxila exibiu excesso vertical; o ângulo goníaco demonstrou-se mais alto; o plano oclusal superior apresentou-se menos 
inclinado; o plano oclusal mandibular apresentou-se mais inclinado; o ângulo goníaco apresentou-se maior; o ângulo do plano mandibular apresentou-se mais alto; o ramo mandibular apresentou-se posicionado mais para baixo e para trás no grupo; a altura facial ântero-inferior e total apresentaram-se aumentadas e a mandíbula apresentou-se menos protruída. Diferenças intergrupos não foram observadas na base do crânio, na posição ânteroposterior da maxila ou dos incisivos superiores e inferiores, no plano palatino, na altura facial posterior, na altura do ramo mandibular ou no comprimento do corpo mandibular. Concluíram que, de uma forma geral, a má oclusão de Classe II, com mordida aberta, é caracterizada por discrepâncias tanto na mandíbula como na maxila, necessitando, muitas vezes, de intervenção cirúrgica em ambos os maxilares para se obter um resultado satisfatório do tratamento.

Uma lista de características faciais de pacientes com mordida aberta, foi estabelecida por LOPEZ-GAVITO ${ }^{81}$, em 1985 na fase pré-tratamento, comparando com um grupo controle com oclusão normal ou que apresentaram mordida profunda, da qual se destacam as seguintes:

$\checkmark$ ângulos dos planos oclusal, mandibular e goníaco excessivos;

$\checkmark$ ângulo do plano palatino diminuído;

$\checkmark$ corpo e ramo mandibular pequenos;

$\checkmark$ altura facial ântero-inferior aumentada;

$\checkmark$ altura facial ântero-superior diminuída;

$\checkmark$ distância násio-básio diminuída;

$\checkmark$ mandíbula retruída;

$\checkmark$ altura facial posterior diminuída e anterior aumentada;

$\checkmark$ tendência à Classe II;

$\checkmark$ planos cefalométricos divergentes;

$\checkmark$ base anterior do crânio inclinada.

O padrão de desenvolvimento do crescimento facial em pacientes com mordida profunda e mordida aberta esquelética, foi estudado por NANDA ${ }^{98}$, em 1988, que se baseou longitudinalmente em radiografias cefalométricas laterais de 16 pacientes do gênero masculino e 16 do feminino, com idade de 3 a 18 anos. Esses pacientes foram selecionados em relação à altura facial inferior, 
como porcentagem da altura facial total, sendo analisadas estatisticamente e graficamente as curvas de crescimento absoluto e incremental da altura facial anterior total, da altura facial ântero-superior, da altura facial ântero-inferior, altura facial posterior e do tamanho do ramo. $O$ autor concluiu que os pacientes com mordida profunda e mordida aberta crescem diferentemente, de forma que, aqueles com mordida profunda, caracterizam-se por terem altura facial ântero-superior aumentada, enquanto os com mordida aberta anterior, apresentam-se com altura facial ântero-inferior aumentada; a altura facial posterior e a altura do ramo não diferiram significantemente entre a mordida profunda e a mordida aberta; o padrão de crescimento em cada forma facial é estabelecido numa idade muito precoce, mesmo antes da erupção dos primeiros molares permanentes e muito antes do surto de crescimento do adolescente. Um gradiente da época do surto de crescimento do adolescente foi evidenciado da seguinte maneira: $1^{\circ}$ ) pacientes com mordida aberta, do gênero feminino, $2^{\circ}$ ) pacientes com mordida profunda, do gênero feminino, $3^{\circ}$ ) pacientes com mordida aberta, do gênero masculino, 4을 pacientes com mordida profunda, do gênero masculino. Esses achados demonstraram haver relevância clínica para a época do tratamento ortodôntico, a duração do período de contenção e a predição da relação oclusal da dentadura mista para a permanente.

Com o intuito de observar se as medidas cefalométricas podem predizer a tendência de um indivíduo desenvolver a mordida aberta ou crescimento vertical excessivo, durante o tratamento ortodôntico, DUNG; $\mathrm{SMITH}^{39}$, em 1988, estudaram cefalometricamente 300 pacientes entre 10 e 16 anos. Os resultados indicaram que, as diferentes medidas em identificar a tendência da mordida aberta diferem entre os pacientes, pois dos 50 pacientes com o ângulo Sn.GoMe maior que 40, apenas 11, tiveram a proporção da altura facial superior para inferior menor do que 0.7 ; dos 50 pacientes com os ângulos do plano oclusomandibular maior do que 22을 apenas 15 mostraram a proporção da altura facial posterior para anterior menor do que 0,58. Dos 250 pacientes que exibiram alguma indicação cefalométrica bem aceita por dimensão vertical excessiva, apenas 13\% teve mordida aberta anterior verdadeira. Quando os clínicos observaram seus próprios pacientes, de acordo 
com a dificuldade em controlar o crescimento vertical excessivo durante 0 tratamento, tais medidas como o ângulo do plano mandibular, a proporção entre a altura facial superior e inferior e a proporção entre a altura facial posterior e anterior, não puderam predizer essa tendência durante 0 tratamento. Concluíram que é bastante variável a tendência de um paciente com as características cefalométricas de mordida aberta e outro que não as apresente, de virem a desenvolvê-la, como um paciente que apresenta mordida profunda no início do tratamento, mas que, durante o mesmo, apresenta respostas típicas de tendência à mordida aberta. A outra dificuldade em se prever a tendência ao crescimento vertical é que o equilíbrio das forças durante o crescimento que resultam em uma mordida aberta é biologicamente diferente do que as características que resultam em mordida aberta durante a aplicação das forças ortodônticas.

A associação dos fatores esqueléticos com o desenvolvimento das desproporções faciais verticais foi avaliada por NANDA ${ }^{97}$, em 1990, que observou as medidas angulares longitudinais das radiografias cefalométricas de 16 pacientes do gênero masculino e 16 do gênero feminino, na idade de 4 a 8 anos. Os pacientes foram selecionados, tomando-se por base a altura facial inferior como porcentagem da altura facial total, obtendo-se uma fotografia intrabucal na idade de 15 anos para os meninos e de 13,5 para as meninas, para classificar a oclusão de cada paciente em mordida aberta ou mordida profunda. Foram analizados estatisticamente e graficamente os ângulos: SN.PP, SN.Ocl, PP.GoMe, SN.GoGn e o ângulo da base do crânio, concluindo que: 1) com exceção dos ângulos SN.PP e da base do crânio, todas as medidas angulares demonstraram progressiva redução durante 0 desenvolvimento em ambos os pacientes com mordidas aberta e profunda; 2) o ângulo PP.GoMe variou entre os grupos de mordida aberta e mordida profunda durante a fase de desenvolvimento; 3) em relação ao sexo, as medidas faciais variaram, com exceção do ângulo da base do crânio e do plano oclusal; e 4) o ângulo da base do crânio demonstrou claramente um dimorfismo genérico e sua magnitude não foi associada com a displasia vertical. A redução progressiva dos ângulos na mordida aberta esquelética reduziu ou manteve os desequilíbrios, enquanto a redução dos ângulos acentuou a mordida profunda 
com a idade. A inclinação do plano palatino e sua constância sugeriu que a rotação para baixo e para trás da mandíbula, nos pacientes com mordida aberta, comprometeu na resposta das mudanças compensatórias dentoalveolares, com o centro de rotação nos molares. A magnitude do ângulo do plano mandibular não é adequada para avaliar a predição do diagnóstico ou prognóstico na determinação do padrão de crescimento. Concluiu ainda que a mordida aberta pode apresentar-se relacionada com uma direção desfavorável de crescimento do complexo maxilomandibular, sendo caracterizada por uma tendência de se apresentarem em faces com altura facial inferior aumentada, conhecida como "síndrome da face longa"131. 


\section{2-Fatores etiológicos}

\subsubsection{Alterações do desenvolvimento facial}

As más oclusões no sentido vertical ocorrem como resultado da interação de vários fatores etiológicos diferentes, e um dos mais importantes é a alteração do crescimento facial, como visto no tópico anterior. As variações no crescimento, função dos tecidos moles e na musculatura facial, tanto quanto como o desenvolvimento dentoalveolar individual, pode também influenciar a evolução dessas más oclusões, podendo ainda serem causadas secundariamente ou agravadas pelos fatores ambientais, como relatam os autores a seguir.

Após estudar os fatores dento alveolares da mordida aberta e da mordida profunda, RICHARDSON ${ }^{122}$, em 1970, avaliou cefalometricamente 110 casos de mordida aberta, em crianças de 7 aos 10 anos, observando que 0 ângulo do plano mandibular e a altura facial inferior foram significantemente maiores, nos casos de mordida aberta, concluindo que a sua causa é devido ao crescimento facial superior deficiente e a altura facial ântero-inferior aumentada, associado a uma falta de crescimento vertical das estruturas dentoalveolares anteriores. Analisou-se que, com o tempo, o crescimento maxilar pode corrigir-se por si próprio, mas que o desenvolvimento vertical das estruturas dentoalveolares não acompanha igualmente esse desenvolvimento, concluindo que a mordida aberta anterior pode ser atribuída tanto a fatores dentários como esqueléticos; portanto, não se justifica a separação desses dois fatores.

A associação de pacientes que apresentavam amelogênese imperfeita com a mordida aberta, foi avaliada por ROWLEY ${ }^{128}$ et al., em 1982, que estudaram clinicamente e cefalometricamente 50 pacientes com amelogênese imperfeita, dividindo-os em dois sub-grupos, um com mordida aberta e outro sem. Concluíram que $24 \%$ do grupo com e mais de $20 \%$ do grupo sem mordida aberta apresentaram padrão de crescimento facial acentuadamente vertical. Concluíram ainda que a freqüente associação da mordida aberta com a amelogênese imperfeita é causada mais por uma anomalia determinada 
geneticamente do desenvolvimento craniofacial do que por fatores locais que possam influenciar no crescimento alveolar.

Há uma importância muito grande em se determinar os possíveis fatores etiológicos nos casos de mordida aberta, para que se possa definir precocemente uma meta terapêutica correta, evitando-se, em casos de displasias esqueléticas, um agravamento dessa, por parte do tratamento, havendo extrusão dentária posterior, ou frustrações. Pois, segundo CANGIALOSI $^{22}$, em 1984, muitas vezes o profissional acredita resolver o problema apenas com uma grade palatina, considerando apenas os fatores ambientais, e, no entanto, o potencial esquelético vertical presente, necessitaria de um outro tipo de conduta clínica. Referindo-se ainda à alteração do crescimento como fator etiológico, de acordo com NIELSEN ${ }^{103}$, em 1991, além das alterações do crescimento vertical do côndilo mandibular, associado a um excessivo crescimento vertical dentoalveolar posterior, resultando em uma rotação da mandíbula no sentido póstero-inferior, a variação na intensidade do crescimento também é um fator que pode afetar a extensão e o resultado do tratamento ortodôntico, tornando-se difícil para o ortodontista controlar o tratamento, nos períodos do surto de crescimento, quando se pode obter apenas um ou dois milímetros nessa fase. Avaliou, primeiramente, durante o tratamento as correções dentoalveolares, e depois, de uma forma mais lenta, as mudanças esqueléticas, o que prolonga o tempo de tratamento e nem sempre são completamente alcançadas. Devido à imprevisibilidade da intensidade do crescimento durante a fase do surto, deve-se tratar precocemente o paciente com mordida aberta, mesmo que o tempo de tratamento seja mais extenso.

\subsubsection{Hábitos bucais deletérios}

Quando existe um padrão morfogenético normal, a língua, os lábios e as bochechas funcionam como mantenedores da homeostasia local. Porém, qualquer interferência na sua homeostasia, no período de crescimento ativo das estruturas da face, pode alterar a morfologia e a função do sistema 
estomatognático, quebrando o equilíbrio dentário e prejudicando 0 desenvolvimento oclusal e esquelético normal. Os hábitos bucais deletérios têm um papel dinâmico na musculatura facial, podendo alterar a forma dos arcos dentários e causar danos às estruturas craniofaciais. Esses danos podem ser temporários ou permanentes, dependendo da persistência, intensidade e duração dos hábitos (Tríade de Graber), sendo também influenciados pela morfologia original dos arcos e pelo padrão e maturação da deglutição. E os desequilíbrios musculares decorrentes de hábitos bucais deletérios durante o período de crescimento facial têm-se demonstrado capazes de interferir o desenvolvimento normal da oclusão dentária, comprometendo a morfologia e a função deste intrínseco sistema estomatognático ${ }^{5,6,7}$.

Ao realizar uma pesquisa em duas escolas de crianças com perturbações mentais e psicóticas, em idade de 7 a 18 anos, GERSHATER ${ }^{54}$, em 1972, observou uma alta incidência de casos com mordida aberta, concluindo que: o padrão neuromuscular alterado, associado a hábitos deletérios, demonstrou ser o principal fator etiológico, acompanhado secundariamente pela hereditariedade do padrão esquelético alterado que, em muitos casos, tornaram-se mais alterados pela existência de hábitos deletérios; a severidade da mordida aberta em relação às alterações das estruturas esqueléticas, pode contra-indicar a necessidade do tratamento, em tais pacientes; quando indicado o tratamento, a placa com grade deve ser instituída, mas sem ganchos que traumatizem a língua; caso tais pacientes aceitem bem o tratamento ortodôntico fixo, esse apenas deve ser instituído após a neutralização ou eliminação da causa, afirmando que uma má oclusão de mordida aberta pode ser evitada por meio de um tratamento adequado das amígdalas palatinas e adenóides hipertróficas em um estágio precoce de desenvolvimento.

A mordida aberta encontra-se correlacionada aos hábitos bucais deletérios em vários relatos na literatura $32,40,89,104,109,134$ sendo praticados por um grande número de crianças, como demonstrado no estudo de SILVA FILHO ${ }^{136}$, em 1990, que pesquisou a prevalência das más oclusões em escolares da cidade de Bauru, observando que a mordida aberta, na fase da 
dentadura mista, encontra-se numa média de 18,5\% da população, e segundo SERRA NEGRA ${ }^{134}$, em 1997, ao avaliar a relação entre hábitos bucais deletérios e o trespasse vertical, encontrou que a má oclusão mais freqüente foi a mordida aberta (31,9\%), apresentando-se um risco de se ter mordida aberta anterior em crianças portadoras de hábitos deletérios, de, aproximadamente, 14 vezes mais, em comparação àquelas que não apresentaram esse comportamento, podendo conduzir a desvios no desenvolvimento facial, atresias do arco dentário, desequilíbrios e hipofunção muscular, disfunções articulares e até problemas psicológicos ${ }^{8,23}$.

Dentre os hábitos bucais deletérios mais comuns na literatura, pode-se citar: a sucção do polegar e outros dedos, interposição de língua, sucção e mordida do lábio, deglutição atípica, sucção de chupeta, lápis e outros objetos, onicofagia e respiração bucal. Alguns autores ${ }^{76,78}$ relatam que os hábitos bucais de sucção sem fins nutritivos, podem persistir até os dois ou três anos de idade sem causar danos à oclusão, considerando-se como hábitos deletérios se passar dessa idade.

\subsubsection{Aleitamento artificial}

Há muito tempo, o aleitamento natural desempenha importante papel na saúde do ser humano, abrangendo o desenvolvimento infantil e a saúde da mulher. Ao longo dos anos, vários autores vêm se preocupando com o estudo da associação entre a forma do aleitamento, a instalação de maus hábitos bucais e, a partir desses, o desenvolvimento das más oclusões. Geralmente os hábitos bucais se instalam com maior freqüência em crianças que não tiveram amamentação natural, pois o impulso neural da sucção está presente desde a vida intrauterina e é normal na criança, garantindo sua sobrevivência. Quando a criança tem amamentação por mamadeiras, o fluxo de leite é bem maior que na amamentação natural, satisfazendo a criança nutricionalmente em menor tempo e com menor esforço. Porém o êxtase emocional em relação ao impulso da sucção não é atingido, e a criança para isso procura substitutos como o dedo, chupetas e objetos para satisfazer-se ${ }^{134,22,149}$. 
SERRA NEGRA et al. ${ }^{134}$, em 1997, constataram que há uma forte associação entre o aleitamento natural com a não-instalação de hábitos bucais, pois $86,1 \%$ das crianças que não os apresentavam foram amamentadas por, no mínimo, 6 meses, e as crianças com hábitos de sucção, quase em sua totalidade, obtiveram aleitamento artificial quando bebês. Ao estudar também a relação entre a amamentação natural e a ocorrência de mordida aberta, ROBLES et al. ${ }^{126}$, em 1999, avaliou a influência do período de amamentação nos hábitos de sucção persistentes e a ocorrência de má oclusões em 164 crianças com dentadura decídua completa, elaboraram um questionário com perguntas sobre o tempo de amamentação natural, presença e tempo de uso de mamadeira e sobre hábitos bucais de suç̧ão (chupeta, polegar e outros dedos), o qual foi aplicado para cada mãe das crianças examinadas, que pertenciam a três creches do grande ABC Paulista. Analisou-se, após os resultados estatísticos, que $64 \%$ das crianças usaram mamadeira após os dois anos de idade, observando-se que:, 1) as crianças amamentadas naturalmente entre 4 e 8 meses, apresentaram menor freqüência que de crianças que usavam mamadeiras após os 2 anos de idade; 2) as crianças que apresentaram um tempo maior de amamentação natural demonstraram uma menor freqüência de hábitos bucais de sucção persistente em comparação àquelas que tiveram um período de amamentação abaixo do ideal; 3) comprovou-se a relação entre a presença de sucção e a ocorrência de má oclusão na dentadura decídua.

\subsubsection{Respiração bucal}

A respiração bucal é causada pela obstrução nasal, oriunda de tonsilas faringeanas hipertrofiadas, rinites alérgicas ou desvios de septo ${ }^{5,6,72}$. A língua, nesses casos, em vez de pressionar o palato, fica numa posição mais abaixada e a mandíbula posiciona-se póstero-inferiormente, liberando os dentes posteriores para uma erupção passiva, proporcionando um aumento da altura facial ântero-inferior e da convexidade facial ${ }^{72}$. Desse modo, um menor 
desenvolvimento transversal da maxila é esperado, pois a língua não pressiona convenientemente o palato, criando também a mordida cruzada posterior.

A "face adenoideana" e o conceito que a forma facial pode ser influenciada pela hipertrofia das adenóides, foram descritos por TOMES ${ }^{147}$, em 1872, apud RUBIN ${ }^{129}$, em 1983. Essa hipótese tornou-se largamente aceitável pela maioria dos ortodontistas em todo o mundo, sendo até os dias de hoje um assunto bastante discutido na literatura ${ }^{125,129,117,79,80}$.

Em um estudo sobre os efeitos da respiração nasal, LINDERARONSON ${ }^{79}$, em 1970, concluiu que problemas respiratórios, tais como adenóides e tonsilas palatinas hipertróficas, ou qualquer obstrução nasal, como: desvios de septo, conchas nasais largas ou alergias, que são freqüentemente observados em casos de ângulos do plano mandibular altos, podendo afetar o posicionamento mandibular, por causar mais liberdade para a erupção dos dentes posteriores, concluindo-se que o ângulo do plano mandibular e a altura facial anterior diminuem após a remoção das adenóides e das amígdalas palatinas. Considerando ainda a associação da respiração nasal com a ocorrência da mordida aberta, AHLGREN ${ }^{1}$, J. E. M. G. em 1995 e CARVALHO, G. D. ${ }^{23}$, em 1996, estudando a atividade dos lábios e dos músculos mastigadores e a síndrome do respirador bucal, respectivamente, concluíram que a respiração bucal não deve ser considerada como um hábito deletério, por seu caráter repetitivo e inconsciente, mas sim pela sua complexidade e características, deva ser considerada como uma síndrome, "A síndrome do respirador bucal ou respirador nasal insuficiente", apresentando as seguintes alterações do sistema mastigatório: lábios hipotônicos, posição mandibular para baixo e para trás, levando à má oclusão de Classe II de Angle, vestibularização dos incisivos superiores, seguida em alguns casos de overjet, estreitamento do arco superior, atresia maxilar transversa, com mordida cruzada bilateral, face longa, palato ogival, seios maxilares atrésicos, apinhamentos, mordida aberta anterior e tônus muscular deficiente. Ocorrendo, em muitos casos, alterações sistêmicas e psicológicas. 


\subsubsection{Interposição lingual}

Por muito tempo, a interposição lingual foi apontada como o principal fator da mordida aberta ${ }^{90,146}$, principalmente nos anos 60 e metade dos anos 70 , em que os ortodontistas americanos apenas iniciavam um tratamento ortodôntico em um paciente com interposição lingual, caso ele já estivesse realizando exercícios para corrigir essa interposição ${ }^{71}$. Atualmente, a interposição lingual é considerada como um hábito secundário, pois se deve principalmente a uma adaptação ao espaço anteriormente existente e, portanto, atua mais como um agravante da mordida aberta, do que propriamente como a sua causa ${ }^{137,144}$. Então é mais correto considerar que o paciente utiliza a língua para selar a região anterior da boca durante a deglutição, por exemplo, a fim de prevenir que líquidos e alimentos escapem, como também a interposição lingual ocorre durante a fala ou durante a própria posição postural de repouso da mesma. Dessa forma, levar os lábios de encontro um ao outro e colocar a língua entre os dentes anteriores separados é a única maneira de se alcançar um selamento anterior ${ }^{115}$. Assim, considera-se que, os hábitos bucais secundários mantêm ou agravam a má oclusão já existente. 


\section{3- Tipos de tratamento}

Observa-se, na literatura, uma variedade ampla de tipos de tratamento para correção da mordida aberta, desde a fase de dentadura decídua até a dentadura permanente. Porém, o propósito deste estudo é avaliar o grau de recidiva dos pacientes com mordida aberta, tratados há mais de cinco anos, após realização do tratamento ortodôntico fixo com extrações, na fase de dentadura permanente. Assim, aborda-se, de uma maneira simples, os tipos de tratamento durante as fases de dentaduras decídua e mista, e com mais enfoque os tratamentos realizados com aparelhos ortodônticos e ortodôntico-cirúrgicos, existentes na literatura, para correção da mordida aberta na fase da dentadura permanente, que é o principal assunto abordado nesta pesquisa.

O diagnóstico e plano de tratamento em pacientes com deformidades dentoesquelética é muito complexo, em particular as más oclusões com mordida aberta, que têm, por muitos anos, deixado o ortodontistas e cirurgiões desanimados com os seus resultados ${ }^{62,92,11,94}$. Deve-se, portanto, para um bom planejamento, avaliar cada má oclusão e suas deformidades esqueléticas, planejando-se cada caso individualmente, ao invés de se adaptar um tipo de má oclusão a um tipo de tratamento. Assim, faz-se necessária a identificação do fator etiológico, sendo essa a chave para um bom planejamento de tratamento, distinguindo-se entre as características esqueléticas e dentárias, de cada caso em particular.

A mordida aberta tem fascinado enormemente a ortodontia por ser difícil de se tratar e de conter. Válidos ou não, muitos artigos têm apresentado várias modalidades de tratamento, de acordo com a etiologia.

Do início dos anos 60 à metade dos anos 70, nos Estados Unidos, valorizou-se muito a correção da interposição lingual, de forma que os ortodontistas dessa época nem mesmo examinavam a má oclusão, se o paciente não tivesse passado antes por uma terapia funcional muscular para corrigir corretamente a língua, caso apresentasse alguma interposição lingual ${ }^{63}$. Assim, a maioria dos tratamentos e contensores ainda hoje utilizam a grade palatina. 
O tratamento da mordida aberta tem envolvido várias técnicas, variando desde a utilização de simples grades palatinas ${ }^{69}$, a forças ortopédicas, incluindo o arco extrabucal de tração alta $^{75}$, corretores funcionais ${ }^{50}$, placas removíveis associadas ao arco extrabucal ${ }^{48}$, bionator para mordida aberta ${ }^{158}$, "bite blocks" passivo e ativo ${ }^{65}$ e intervenção ortodôntica até a correção ortodôntico-cirúrgica.

Como visto no tópico anterior, a mordida aberta pode se apresentar por uma infinidade de fatores etiológicos, considerando-se alteração no padrão de crescimento facial, o fator mais problemático, pela dificuldade em alterá-lo, principalmente quando este é severo. Entretanto, há determinados casos que se corrigem quando o crescimento é satisfatório, mesmo na presença de hábitos deletérios, adenóides ou amígdalas hipertróficas ${ }^{114,143}$, o que torna difícil para o clínico saber se o fechamento, nessa fase, deu-se pela utilização do aparelho, quando utilizado, ou pelo próprio direcionamento do crescimento facial. Portanto, PROFFIT ${ }^{114}$, em 1975, recomenda tratar as mordidas abertas, apenas após o surto de crescimento, sendo criticado por JUSTUS ${ }^{69}$, em 1976, argumentando que, por outro lado, a mordida aberta pode acentuar, levando a uma mordida aberta esquelética e comprometendo ainda mais a sua estabilidade após o tratamento. O mesmo apresentou seis casos clínicos tratados na dentadura mista, apenas com grades palatinas fixas, que foram publicadas e utilizadas pela primeira vez por ROGERS ${ }^{127}$, em 1927, associando-se ao arco extrabucal com tração alta e acompanhamento de terapia miofuncional, obtendo-se o fechamento da mordida em todos os 6 casos, concluindo que a grade força a língua a posicionar-se normalmente durante a deglutição, e na posição de repouso mandibular, interceptando as más oclusões antes que ocorra uma deformidade na dentição permanente, ou, mesmo que ocorra, será bem mais suave.

Quanto às questões psicológicas que possam existir pela remoção destes hábitos, GRABER ${ }^{57}$, em 1958, relatou que, após mais de 600 casos tratados, não observou nenhum caso de transferência de hábito.

Assim, é importante ressaltar que a fase de eleição para o tratamento da mordida aberta se faz durante a dentadura decídua e mista, quando se pode 
evitar um comprometimento esquelético ou, mesmo que já possua, tentar suavizá-lo.

\subsubsection{Tipos de tratamento durante a dentadura decídua e mista}

Ao considerar que a mordida aberta pode ser causada por incompetência labial, sendo essa devido a uma pobre atuação postural de cadeia dos músculos verticais anteriores, FRANKEL ${ }^{49}$, em 1983, preconizou exercícios labiais, com o aparelho regulador de função, com o objetivo de ativar e aumentar o tônus muscular, promovendo o selamento bucal anterior e elevando a mandíbula para a sua posição adequada.

Ao estudar a mordida aberta e o tratamento para sua correção com a técnica "multiloop edgewise", $\mathrm{KIM}^{71}$, em 1987, afirmou que o aparelho extrabucal, com tração alta, não demonstra evidência cefalométrica de redução da distância entre os molares superiores e o plano palatino, da mesma forma que a mentoneira, aplicada principalmente em pacientes com a "síndrome da face longa" ou "face adenoideana", com o objetivo de redirecionar o crescimento mandibular, não tem validade científica comprovada, com alguns casos agravados, pois principalmente nos respiradores bucais pode proporcionar um efeito adverso, na tentativa desses pacientes respirarem pela boca. Concluiu ainda que a presença de uma mordida aberta, em pacientes com padrão de crescimento normal ativo, pode corrigir-se espontaneamente, desde que seja instituído ao paciente um tratamento cuidadoso para remoção de algum hábito deletério que ele possa ter.

Os efeitos da utilização do regulador de função de Fränkel, foram estudados por ERBAY et al. ${ }^{44}$, em 1995, no tratamento da má oclusão de Classe I, com mordida aberta anterior esquelética, em uma amostra de 40 crianças da Turquia, em fase de crescimento, estabelecida por radiografias carpais, comparando-as a um grupo-controle, com mordida aberta, sem tratamento. Analisaram que o FR-4 (regulador de função), apresentou efeitos significantes no tratamento da mordida aberta, em que o padrão de crescimento e desenvolvimento da mandíbula foi alterado, de forma que o 
grupo-controle apresentou um crescimento mandibular para baixo e para trás, enquanto o grupo tratado apresentou crescimento para cima e para frente, permitindo que a mordida aberta fosse corrigida com sucesso, por meio do movimento de rotação da mandíbula para cima e para frente, concluindo que esse resultado fora devido ao treinamento do selamento labial realizado pelo aparelho.

Por meio de estudos clínicos e cefalométricos, DELLINGER ${ }^{35}$, em 1986, analisou a utilização dos magnetos incorporados aos "bite blocks", para correção da mordida aberta anterior, denominando-os de corretor vertical ativo IV, consistindo de blocos de acrílico oclusais superiores e inferiores contendo quatro pares de magnetos repulsivos entre si, colocados oclusalmente na região posterior, com uma força de $1400 \mathrm{gr}$, quando as placas apresentam-se em contato. Os resultados demonstraram uma rápida intrusão dos dentes posteriores e rotação anterior da mandíbula, obtendo o fechamento satisfatório das mordidas abertas, e, pela análise 3 anos após o término do tratamento, concluiu que não houve uma recidiva significante de extrusão dos dentes posteriores, e que esse método de tratamento é uma boa opção para pacientes adultos, considerando os riscos de uma cirurgia ortognática e sua possibilidade de recidiva.

Idealizando uma nova proposta de tratamento das mordidas abertas esqueléticas, WOODS; NANDA, ${ }^{154}$ em 1991, estudaram o uso de aparelhos magnéticos com forças repulsivas, em quatro animais babuínos fêmeas, com 9 anos, após o término de crescimento, concluindo que o uso dessas forças opostas causa intrusão dos dentes posteriores, permitindo que a mandíbula rotacione para cima e para frente, da mesma forma que ocorre com as cirurgias para impacção maxilar. E que essa alteração na quantidade e direção do deslocamento maxilar ocorre da mesma maneira quando os animais estão em crescimento, com mudanças na forma mandibular e erupção dos dentes anteriores com conseqüente fechamento da mordida aberta.

PEARSON ${ }^{110}$, em 1991, apresentou um caso clínico, de um paciente em fase de dentadura mista, apresentando uma Classe II, divisão I completa, com maxila protruída e atrésica, uma acentuada mordida aberta anterior, 
apresentando respiração bucal, sucção de polegar e interposição lingual, com padrão de crescimento acentuadamente vertical. Utilizou a mentoneira durante 12h/dia, por um período de cinco meses, realizando também expansão rápida da maxila e, após, instalou um "bite block" por 10 meses, juntamente com o uso da mentoneira. Após esse período corrigiu-se completamente a mordida aberta, com uma redução da AFAl, de 75 para $72 \mathrm{~mm}$, instalando o aparelho ortodôntico fixo "edgewise", com arco extrabucal de tração occiptal, realizando extrações dos segundos molares superiores devido a altura facial excessiva. Ao final do tratamento, ainda havia interposição lingual, instalou-se uma grade palatina fixa, e a paciente foi indicada ao otorrinolaringologista, devido a constante respiração bucal. A contenção instituída após a finalização do tratamento foi uma placa de acrílico com um orifício na região do palato, continuando-se com a utilização da mentoneira apenas à noite, como também um $3 \times 3$ inferior. Concluiu que, em casos limítrofes de cirurgia ortognática, deve-se controlar as forças utilizando-se todos os recursos necessários para evitar a extrusão dos dentes posteriores, restringindo o desenvolvimento vertical posterior, controlando-se os hábitos e principalmente necessita-se de uma total colaboração do paciente para que tal mecânica possa realizar-se.

Utilizando forças magnéticas DARENDELILER; YÜKSEL; MERAL ${ }^{30}$, em 1995, apresentaram o ativador magnético IV, para correção da mordida aberta, o qual consiste de placas superior e inferior com magnetos repulsivos introduzidos na região posterior e magnetos atrativos na região anterior, podendo ser utilizados tanto na dentadura mista quanto na permanente. A força de intrusão na região posterior é de $300 \mathrm{~g}$, causando uma abertura de mordida na região dos molares de 5,5 a $6 \mathrm{~mm}$, e os dois magnetos utilizados na região anterior exerce uma força atrativa de $300 \mathrm{~g}$, tendo como resultado o fechamento da mordida aberta pela extrusão dos dentes anteriores e intrusão dos dentes posteriores, proporcionando uma rotação mandibular no sentido anti-horário, sem demonstrar nenhum efeito de mordida cruzada, como ocorre com a utilização dos magnetos utilizados na região posterior. Porém, o número de pacientes tratados com esse tipo de aparelho ainda é insuficiente para relatar conclusões definitivas; entretanto, com mais de 15 pacientes tratados na 
Universidade de Gazi, na Turquia os melhoramentos esqueléticos e dentários parecem promissores.

Estudos clínicos e em animais, realizados por MOSS et al. ${ }^{91}$, em 1993, e WOODS; NANDA ${ }^{154}$, em 1991, comparando os blocos de mordida magnéticos e não-magnéticos, mostraram que as correções das mordidas abertas foram mais pronunciadas quando os magnetos foram usados, mas que a tendência da recidiva também foi maior. Outro fator desfavorável relatado é o aparecimento da mordida cruzada observado algumas vezes durante 0 tratamento, por causa da falta de controle devido ao desvio dos magnetos da porção central, pois quando em contato eles tendem a empurrar um contra 0 outro, havendo um desvio.

\subsubsection{Tipos de tratamento na dentadura permanente}

Apesar de o tratamento ortodôntico, na dentadura permanente, ser mais indicado nos casos de comprometimento dentoalveolar, e o ortodônticocirúrgico nos casos com envolvimento esquelético, existem muitos casos na literatura, relatados a seguir, de mordidas abertas esqueléticas, que foram bem resolvidas apenas com o tratamento ortodôntico. Porém, em muitos, não há um estudo a longo prazo e não se conhece sua estabilidade.

Uma amostra de 25 pacientes, com mordida aberta, foi analisada cefalometricamente por DE COSTER ${ }^{34}$, em 1935, observando que a mordida aberta anterior não se limitava a uma só região da face. Concluiu que se tratava de um problema esquelético com desvios mandibulares, maxilares e da base do crânio. Comentou alguns métodos até então propostos para solução do problema, mostrando-se favorável aos desgastes oclusais dos molares, a um nível suficiente, para permitir que os dentes anteriores entrem em oclusão. Acrescentou que, em alguns casos, o desgaste dos molares poderia até exigir a desvitalização do dente; em outros, julgava aconselhável a extração dos dentes que se constituíam em obstáculo no fechamento da mordida. 
O tratamento ortodôntico de 6 casos de mordida aberta anterior, com idade entre 12 e 20 anos, foi apresentado por COMPOSTELA ${ }^{27}$, em 1952,em que os pacientes foram tratados com aparelho ortodôntico fixo e elásticos verticais intermaxilares, concluindo que esse tipo de tratamento provoca uma extrusão dos dentes anteriores.

Preocupado também com o tratamento das mordidas abertas anteriores, COSTA DEL $\mathrm{RIO}^{28}$, em 1957, recomendava para a correção, o uso de um aparelho para a extrusão dos incisivos, sem provocar efeitos secundários de extrusão nos molares. Esse aparelho era usado conjuntamente com uma mentoneira de tração vertical, de forma que permitisse uma intrusão dos molares para reduzir a altura do terço inferior da face. Associava ainda elásticos intermaxilares, considerando um estímulo para produzir a transformação do osso alveolar, permitindo a recuperação dos tecidos e continuação da formação dos osteoblastos.

Ao comparar cefalometricamente 25 pacientes maiores de 12 anos, com mordida aberta anterior, com outro grupo de 30 pacientes com oclusão normal, SUBTELNY \& SAKUDA ${ }^{145}$, em 1964, concluíram que o tratamento ortodôntico das mordidas abertas esqueléticas poderia ser impossível. Para os autores $^{145}$, em muitos casos, a melhor conduta é não tentar tratamento ortodôntico, e realizar o cirúrgico após o crescimento. Enfatizaram ainda que o uso de elásticos verticais intermaxilares podem extruir os dentes anteriores além dos limites de erupção e, conseqüentemente, haverá uma recidiva da mordida aberta, assim que os elásticos forem suspensos.

DE MICHELIS \& HERTEL ${ }^{36}$, em 1967, afirmaram que a mordida aberta acompanhada pelos desvios esqueléticos e das alterações do perfil representa uma das mais difíceis anomalias de se corrigir e, freqüentemente, requerem não só a presença do ortodontista mas também a intervenção do cirurgião. Relataram que, em muitos casos de mordida aberta, há a necessidade de utilizar arcos metálicos flexíveis em direção vertical ou forças elásticas intermaxilares e, em casos extremos, até a extração de dentes para tentar obter resultados positivos. 
Vários métodos para correção da mordida aberta foram citados por VATTEONE, ${ }^{151}$ em 1969, considerando os mais eficientes, a utilização de elásticos verticais para a correção da mordida aberta acentuada, ou seja, de caráter esquelético, recomendando para os casos em que só existe contato oclusal dos molares, o desgaste de suas superfícies oclusais ou mesmo extrações. Outro método de tratamento da mordida aberta anterior, apresentado em 4 casos clínicos, de pacientes com idade entre 12 a 18 anos, tratados por meio de planos oclusais de borracha colocados em placas removíveis, visando à intrusão dos dentes posteriores, foi publicado por PEQUEÑO BOTARRO et al. ${ }^{111}$, em 1973. Os mesmos concluíram que, a correção dos hábitos e anomalias das mordidas abertas em dentadura permanente é difícil e de prognóstico incerto.

Em um amplo trabalho, SUBTELNY \& SUBTELNY ${ }^{143}$, em 1973, estudaram, sob vários aspectos, o tratamento ortodôntico da mordida aberta, observando que a relação dos segmentos posteriores parece ser tão importante quanto a má oclusão do segmento anterior. Destacaram a importância do controle da altura dentoalveolar dos segmentos posteriores, tentando impedir uma maior abertura da mordida durante 0 tratamento ortodôntico. Salientaram que o tratamento deve ser estabelecido visando à reduzir a altura da mordida anterior, acrescentando-se que, em alguns casos, torna-se conveniente a remoção dos segundos pré-molares, visando à mesializar o segmento posterior; em outros, julgavam aconselhável mesmo a extração dos primeiros ou até dos segundos molares.

LIBERMAN; GAZIT ${ }^{78}$, em 1978, afirmaram que o tratamento ortodôntico deve apenas ser instituído após a correção das atividades musculares bucais, possibilitando ao ortodontista observar a colaboração do paciente antes de iniciar o tratamento. O mesmo apresentou um caso clínico, de uma paciente com 14a 3m, com uma má oclusão de Classe I, apresentando mordida aberta esquelética, com interposição lingual, em que se optou pelo tratamento miofuncional para depois tratar ortodonticamente, realizando extrações dos quatro segundos pré-molares, obtendo-se um completo fechamento da mordida aberta ao final do tratamento, utilizando-se uma placa 
de Hawley por 6 meses como contenção, e 18 meses após a contenção, a oclusão encontrava-se estável. Concluíram que, mesmo em casos com comprometimento esquelético, pode-se obter bons resultados com 0 tratamento ortodôntico, desde que a língua apresente uma função normal.

A mecânica conhecida por "multiloop edgewise archwire" (MEAW), pesquisada e avaliada por 19 anos, foi apresentada por $\mathrm{KIM}^{71}$, em 1987, que demonstrou corrigir qualquer tipo de má oclusão, de forma que o arco dentário já esteja alinhado, sem rotações ou diastemas, por meio de alças verticais e horizontais que proporcionam uma intercuspidação mais detalhada e estável. Para correção da mordida aberta, esse arco superior é acentuado, e o inferior revertido, instituindo a utilização de elásticos intermaxilares apenas na região anterior, passando-os pelas alças dos caninos, recomendando-se elásticos 3/16 polegadas, com força pesada, proporcionando aproximadamente $50 \mathrm{~g}$ de força na região anterior do arco, com a mandíbula em repouso, podendo chegar até $150 \mathrm{~g}$ quando a mordida aberta for moderada, sendo utilizados por todo o tempo, exceto durante a alimentação e higiene bucal. Concluiu-se que esta técnica é de grande valor científico e clínico, apresentando bons resultados a longo prazo.

A decisão quanto às extrações ou não de dentes como auxiliar no tratamento ortodôntico, muitas vezes causa dúvidas aos ortodontistas. Em muitos casos ortodônticos, para se corrigir a mordida aberta, faz-se necessário tanto para resolver discrepâncias no sentido ântero-posterior, vertical e de apinhamentos dos arcos. YAMAGUCCHI ${ }^{156}$, em 1991, estudou 48 pacientes que foram tratados sem extração e 73 com extrações, ambos os grupos com idade média de 12 anos e 2 meses, realizando-se apenas tratamento ortodôntico fixo, com o objetivo de avaliar os efeitos das extrações, na rotação posterior da mandíbula e na posição do gnátio. A amostra constituiu de 19 pacientes do grupo sem extração e 39 do grupo com extração, que utilizaram o arco extrabucal com tração alta, 12 do grupo sem extração e 6 do grupo com extrações, que utilizaram arco extrabucal com tração baixa, 13 pacientes do grupo com extração e 16 do grupo sem extração que utilizaram elásticos intermaxilares. Comparou as radiografias cefalométricas antes e após o 
tratamento, selecionando os casos com extração, pelo acentuado padrão vertical de desenvolvimento facial, concluindo que no grupo sem extração, o tipo de aplicação da força não teve efeito significante nas mudanças esqueléticas e dentárias; já no grupo com extrações, o tipo de aplicação da força teve um efeito significante nas alterações das medidas dentárias.

O padrão morfogenético da face e os procedimentos do tratamento podem proporcionar um grande efeito na posição da mandíbula ${ }^{132,133,38,75}$. Assim, muitos ortodontistas recomendam extrações dos pré-molares em pacientes com grande altura facial anterior, plano mandibular acentuadamente aberto e mesmo quando as discrepâncias esqueléticas e dentárias sejam suaves, com o objetivo de movimentar os molares para mesial, permitindo assim o fechamento da mordida, pela rotação em sentido anti-horário da mandíbula ${ }^{75,44,110}$.

Quanto ao tratamento ortodôntico com extrações dos primeiros molares, $\mathrm{KIM}^{71}$, em 1987, não o recomenda, devido ao grande espaço existente com a ausência desses, sendo necessária muita mesialização do $2^{\circ}$ e/ou 3ำ molares, o que propicia muita inclinação, considerando essa conduta um procedimento difícil e não apropriado, além de que esses dentes são considerados muito importantes para mastigação. Então, recomenda-se a extração do 2ํㅜ ou 3ํำ molar em casos de mordida aberta .

Ao demonstrar um caso clínico de uma paciente, com 11anos e 8meses, que apresentou, ao exame clínico, disfunção da articulação temporomandibular, mordida cruzada, interposição lingual e mordida aberta anterior, LEE ${ }^{76}$, em 1993, concluiu que, a disfunção da ATM fora causada pela mordida cruzada unilateral, a qual induziu a um desvio mandibular, e devido às dores articulares, a paciente posicionava a língua entre os dentes para proteger dos contatos oclusais traumáticos, o que favoreceu a instalação de uma mordida aberta, pela abertura mandibular constante. Demonstrou que, após a expansão para corrigir a mordida cruzada, a paciente foi solicitada a utilizar uma placa de acrílico com cobertura oclusal reposicionando o arco dentário inferior apropriadamente com duração de 2 anos. Obtendo total desaparecimento dos sintomas da disfunção articular, foi então instalado o 
aparelho fixo, para correção da mordida aberta e, após a finalização deste, a paciente utilizou uma placa de acrílico posicionadora por 10 meses, apenas à noite, e depois desse período, foi removida e a paciente observada a cada três meses, apresentando, após cinco anos do tratamento, uma oclusão estável. WILLIAMSON ${ }^{153}$, em 1985, confirmou, em cinco casos clínicos semelhantes, os mesmos resultados. LOWE ${ }^{82}$, apud $\operatorname{LEE}^{76}$, em 1993, após estudar os mecanismos neurais envolvidos no posicionamento da língua, afirmou, que a atividade dos músculos genioglosso aumenta como reflexo da abertura da mandíbula e também pelos estímulos proporcionados pelos ramos periféricos do nervo temporoauricular, que inerva a ATM. Então, como a mandíbula é mantida suavemente aberta para evitar desconfortos, a língua é protruída como uma ação reflexa.

O tratamento da má oclusão de mordida aberta foi considerado por GOTO ${ }^{56}$, em 1994, um dos mais difíceis de ser resolvido, em decorrência da interação de múltiplos fatores etiológicos, pois essa se encontra freqüentemente associada com outras más oclusões, tais como: discrepâncias ântero-posteriores, transversais ou verticais. Quando associada com más oclusões esqueléticas, a mordida aberta pode ser difícil de ser controlada após o tratamento, principalmente se as relações verticais maxilomandibulares forem aumentadas pela extrusão dentária.

Ao considerar a mordida aberta excessiva, uma má oclusão difícil de tratar, GOTO ${ }^{56}$, em 1994, concluiu que isso se deve às dificuldades em mudar permanentemente as desarmonias morfológicas e as alterações funcionais associadas a essa má oclusão; entretanto, considerou que, em alguns casos, com menos envolvimento esquelético, pode ser possível corrigir ortodonticamente a desarmonia oclusal, conforme a nova relação dos arcos dentários tornar-se compatível com a função normal, podendo-se alcançar grande estabilidade se a mecânica utilizada não extruir os dentes posteriores. O mesmo apresentou um caso clínico de uma paciente adulta, com 20 anos, apresentando sintomas de disfunção articular, má oclusão de Classe II, divisão 1, subdivisão, com mordida aberta de 7,5mm, esquelética, mordida cruzada unilateral, com interposição lingual durante a deglutição, maxila protruída e 
mandíbula retruída. O tratamento ortodôntico-cirúrgico foi o de escolha, porém a paciente não aceitou a cirurgia, realizando-se apenas o tratamento ortodôntico fixo com a técnica "multiloop", realizando-se anteriormente uma expansão com o quadrihélice, a qual relatou, após a expansão, eliminação de todos os sintomas, utilizando-se, após esse aparelho, uma placa de contenção e a instalação do aparelho fixo, utilizando-se elásticos intermaxilares anteriores. Obteve-se, após 36 meses de tratamento, o completo fechamento da mordida. A fase de contenção instituída foi de 10 meses de uso integral; após esse período, a paciente foi instruída a utilizá-la apenas à noite, porém utilizou apenas por dois meses e interrompeu. Avaliou-se, após dois anos de tratamento ativo, demonstrando a ocorrência de uma recidiva mínima da sobremordida alcançada. Conclui-se, nesse caso, que o melhor tipo de tratamento em casos de mordida aberta esquelética é mesmo o cirúrgico.

Em 1996, ENACAR ${ }^{42}$, modificou a técnica original de KIM, utilizando fios de níquel-titânio .016" X .022", com curva acentuada no arco superior e reversa no arco inferior, associados aos elásticos intermaxilares aplicados na região de caninos. Desse modo, o plano oclusal era nivelado sem alterações verticais na posição dos incisivos, provocando maior movimento de intrusão dos dentes posteriores. O autor preconiza que a técnica produz resultados similares à técnica do MEAW e ainda promove melhores condições de higienização ao paciente e menor tempo clínico ao ortodontista.

KÜÇÜKKELES et al. $^{74}$, em 1999, avaliaram cefalometricamente 17 pacientes com idade média de 19 anos, apresentando um padrão de crescimento esquelético facial acentuadamente vertical, com mordida aberta anterior. Após o nivelamento inicial, inseriram um fio de níquel-titânio, com curva reversa inferior e acentuada superior, utilizando-se elásticos intermaxilares na região anterior de canino a canino. Realizaram radiografias cefalométricas ao início do tratamento e, em média, 2,8 meses após o fechamento da mordida aberta. Os resultados obtidos indicaram que a correção da mordida aberta foi alcançada principalmente devido à extrusão dos incisivos inferiores e verticalização dos molares inferiores. Após um ano de contenção, avaliaram clinicamente e, por meio dos modelos, analisaram que as posições 
dos incisivos superiores e inferiores, mantiveram-se estáveis, como também a inclinação do plano oclusal. Entretanto, os molares superiores e inferiores extruíram, reduzindo a sobremordida alcançada após o tratamento. Concluiram que esse método de tratamento apresenta-se mais confortável para o paciente do que a técnica de arcos com alças, como também apresenta uma aplicação mais fácil.

Além de conhecer os tipos de tratamento para correção da mordida aberta, o ortodontista deve observar as forças oclusais que, durante as alterações funcionais oclusais, como o bruxismo, o apertamento e em outras alterações anormais podem levar a desordens temporomandibulares e desgastes dentários. Da mesma forma, a ausência dessas forças também pode causar problemas, como: extrusão, inclinações indesejáveis e desequilíbrios oclusais, proporcionando assim interferências oclusais e contatos prematuros ${ }^{4}$.

Alguns estudos ${ }^{138,148}$ têm demonstrado que pacientes com padrões de crescimento vertical tem menos força oclusal do que aqueles com padrão de crescimento normal. Concluíram que os bebês raramente apresentam um padrão de crescimento esquelético vertical, e que esse desenvolvimento se dá certamente pela insuficiência das forças oclusais durante o crescimento, que, segundo ALEXANDER ${ }^{3}$, em 2000, em um estudo, observou a correlação direta com as alterações dos músculos mastigatórios, conforme observados em pacientes com hábitos deletérios, concluindo que tais pacientes só devem ser tratados após o início da remoção dos hábitos, estabelecendo uma proposta de exercícios, para que os pacientes sigam diariamente. Alguns autores ${ }^{62,122}$ ainda afirmam que nenhuma mecânica de tratamento ortodôntico para correção da mordida aberta pode apresentar um resultado satisfatório sem um desenvolvimento funcional normal da língua.

Outro tipo de tratamento que pode ainda ser indicado nessa fase de dentadura permanente, é a utilização de implantes, como auxiliar no tratamento ortodôntico, para o fechamento das mordidas abertas. PROSTERMAN ${ }^{116}$, em 1995, apresentou um caso clínico para a correção da mordida aberta esquelética por meio da utilização de implantes osteointegrados no arco inferior. O paciente apresentava 25 anos, tendo sofrido um trauma na mandíbula, perdendo os incisivos inferiores, o canino e o $1^{\circ}$ pré-molar inferior 
direito. Nove meses depois, o paciente retornou ao hospital, Jewish Hospital Dental Clinic, para tratamento, apresentando-se com interposição lingual, sendo encaminhado a um ortodontista. O mesmo reapareceu 4 meses depois, apresentando uma mordida aberta anterior acentuada, mordida cruzada na região posterior do hemi-arco direito, com uma curva de Spee acentuada e os incisivos superiores e caninos apresentavam-se acentuadamente inclinados para vestibular. Foi instituído então a utilização de três implantes ${ }^{20}$ de $15 \mathrm{~mm}$, na região dos dentes perdidos, com próteses fixas, seguidas pela correção ortodôntica da má oclusão, juntamente com elásticos intermaxilares para correção da mordida cruzada posterior e um aparelho de acrílico colado na oclusal dos dentes posteriores, com o objetivo de intruí-los, como também elásticos verticais na região anterior, possibilitando o total fechamento da mordida e a correção da interposição lingual, finalizando-se o tratamento completo em dois anos e meio. Logo em seguida, instalou-se uma placa de Hawley com o orifício no palato, para interposição apropriada da língua durante a deglutição.

Após dois anos de contenção, observou-se um grau médio de recidiva, provavelmente devido ao padrão de interposição lingual e à pouca colaboração do paciente durante essa fase, além de que o mesmo sofreu outro trauma na mandíbula, desta vez com fraturas. Concluiu que as próteses sobre implantes proporcionam uma ótima ancoragem, tanto no controle da altura facial anterior, evitando-se tanto a extrusão dos dentes posteriores quanto a ancoragem para o fechamento da mordida aberta por meio de elásticos na região anterior.

Ao utilizar os implantes como ancoragem durante o tratamento da mordida aberta ARAT $^{9}$, em 1992, relatou que existe uma grande dificuldade por parte dos ortodontistas em controlar a mordida aberta esquelética, principalmente durante o crescimento, apresentando, muitas vezes, regressão dos casos durante o tratamento ortodôntico, mas que, às vezes, recidivam, devido à falta de um controle total de ancoragem, como demonstrado por meio dos implantes osteointegrados ${ }^{20}$.

Observando a literatura, concernente ao tratamento da mordida aberta por meio da intervenção cirúrgica associada à ortodôntica, GILE ${ }^{55}$, em 
1973, após avaliar cefalometricamente casos tratados de mordida aberta anterior, observou na literatura que existe uma concordância considerável entre os autores ao afirmarem que, após a puberdade, o prognóstico, apenas com o tratamento ortodôntico, apresenta-se duvidoso.

Ao estudar 19 pacientes adultos jovens do sexo feminino, com relação molar de Classe I, FROST ${ }^{52}$, em 1980,comparou com um grupo de 13 pacientes adultos jovens do sexo feminino, apresentando mordida aberta esquelética, que se submeteram ao tratamento ortodôntico cirúrgico, com o objetivo comum de reposicionar a região posterior da maxila para cima. Comparou cefalometricamente o grupo antes do tratamento cirúrgico, imediatamente após e a longo prazo. Os resultados indicaram que existe uma diferença estatisticamente significante das medidas cefalométricas esqueléticas entre os pacientes com oclusão normal e o grupo com mordida aberta. Concluiu que a cirurgia proporciona o reposicionamento maxilar posterior em direção superior corrigindo o padrão esquelético alterado, aproximando as medidas esqueléticas a valores normais. E um controle realizado após 19 meses demonstrou total estabilidade.

Diante de um prognóstico insatisfatório para mordida aberta esquelética, ou de qualquer escolha viável de tratamento, $\mathrm{KIM}^{71}$, em 1987, afirmou que, a abordagem cirúrgica muitas vezes é a indicada, para se obter um resultado estético e funcional satisfatório. Entretanto, é difícil justificar o risco da cirurgia e do trauma, especialmente se a estabilidade da correção cirúrgica não possa ser assegurada ao paciente, sendo difícil justificar o tratamento ortodôntico combinado ao cirúrgico para corrigir uma mordida aberta moderada, quando o resultado cirúrgico pode causar uma seqüela permanente de parestesia ou paralisia facial, independentemente da perfeição da técnica e do resultado oclusal imediato.

Muitos autores ${ }^{31,43,55,131}$ estão de acordo que, para se obter uma boa oclusão, na fase de dentadura permanente, faz-se necessária em alguns casos, a atuação cirúrgica apenas da região posterior ou total da maxila, para proporcionar uma boa intrusão, obtendo, conseqüentemente, uma autorotação da mandíbula, no sentido anti-horário. Entretanto, se existe micrognatia mandibular, deve-se indicar a atuação cirúrgica para o avanço, embora os 
procedimentos nos ramos ascendentes devam ser evitados por proporcionarem um alto potencial de recidiva ${ }^{88,113}$. Porém, o uso da fixação rígida interna evita a recidiva, tornando possível essa abordagem, como demonstrado por REIKIK ${ }^{119}$, em 1990, que estudou uma amostra de 16 pacientes com mordida aberta esquelética, tratados ortodonticamente, juntamente com osteotomia para avanço mandibular, utilizando-se a fixação interna rígida. Após um ano, avaliou os resultados, comparando-se com as medidas cefalométricas iniciais, concluindo que se obteve total estabilidade em todos os contatos oclusais.

\subsubsection{Considerações fonoaudiológicas}

É de grande importância observar a necessidade da terapia miofuncional, após o término do tratamento, pois o tratamento ortodôntico isolado, ou também associado ao cirúrgico, apenas corrige as alterações morfológicas dos arcos dentários e maxilares respectivamente, sem, contudo normalizar os padrões funcionais musculares. Porém, para que haja estabilidade dos resultados ortodônticos, tanto a forma quanto a função do sistema estomatognático devem estar corretas. Assim, a terapia miofuncional, realizada por um fonoaudiólogo, ao final do tratamento ortodôntico, é aceita como um valioso auxiliar de tratamento, levando à reeducação das funções musculares da língua e dos lábios, adequando-os quanto à propriocepção, o tônus e postura de repouso ${ }^{66,93}$. O paciente somente deve ser encaminhado para a mioterapia se apresentar o meio bucal favorável para a correção das funções, ou seja, primeiramente deve-se corrigir a forma e depois a função ${ }^{59,78}$. Portanto quando a forma é corrigida, a própria função tem uma melhora significativa $^{46}$. A avaliação de um fonoaudiólogo determina a necessidade ou não do processo de reeducação funcional. Assim, a automatização do padrão correto da língua em repouso e em fonação somente é conseguida após o tratamento ortodôntico das mordidas abertas. 


\section{4-Estabilidade}

A estabilidade pós-tratamento tem sido o objetivo principal do tratamento ortodôntico e está intrisecamente relacionada com o sucesso do tratamento, e este com o diagnóstico correto, identificando-se as alterações do complexo dentofacial, seus fatores etiológicos e, conseqüentemente, utilizandose a forma de tratamento mais adequada, pelo conhecimento de suas limitações e possibilidades, planejando-se a contenção de acordo principalmente com o que é obtido durante o tratamento ${ }^{61}$

A contenção depois do tratamento ortodôntico finalizado foi definida por REIDEL ${ }^{118}$, em 1969, como "a manutenção dos dentes em suas posições estéticas funcionais ideais" e por MOYERS ${ }^{93}$, em 1991, como "a manutenção dos dentes em suas posições finais, após o tratamento ortodôntico terminado, por um período de tempo necessário."

Após estudar a má oclusão de mordida aberta, COMPOSTELA ${ }^{27}$, em 1952, relatou que o melhor aparelho de contenção é o mesmo arco metálico, utilizado durante o tratamento, em forma passiva ou o uso de uma placa de Hawley, com o arco vestibular apoiado nos braquetes dos dentes anteriores, evitando-se a recidiva.

Segundo BLAKE; BIBBY ${ }^{19}$, em 1998, a proposta de se manter os dentes em suas posições corrigidas após o tratamento, tem como objetivo permitir a reorganização gengival e periodontal, minimizar as mudanças com o crescimento e permitir a adaptação neuromuscular com as posições dentárias corrigidas.

A maioria dos ortodontistas preocupa-se em manter os resultados dos seus casos tratados, embora a tendência dos dentes anteriores, retornarem a suas relações verticais iniciais, após o tratamento ortodôntico, seja bem reconhecida. Após um estudo sobre a recidiva da sobremordida profunda e da mordida aberta, em 26 pacientes, NEMETH; ISAACSON ${ }^{101}$, em 1974, concluíram que duas possibilidades teóricas, explicam esse retorno. Uma delas é o movimento vertical dos dentes juntamente com as alterações de 
desenvolvimento mandibular ou maxilar, podendo ser chamada de alteração dente-osso. Isso pode ocorrer por uma translação vertical (sem alteração na inclinação axial) ou ser rotacional, com alteração da inclinação axial do dente ou dentes envolvidos (o ápice do dente não se move verticalmente). A outra teoria possível de alteração é o movimento vertical de um maxilar em relação ao outro, o que proporcionaria as novas posições verticais dos dentes entre si, podendo-se chamar de alteração osso-osso. Um exemplo desta relação, pode ocorrer por maior incremento vertical proporcionalmente na altura facial anterior do que na altura facial posterior; a mandíbula permanecerá numa direção inferior, tendendo abrir a mordida. Esses mesmos autores pesquisaram se as alterações na relação vertical entre as bases ósseas, produzidas pela rotação mandibular, resultantes do crescimento vertical do côndilo, das suturas maxilares ou dos processos alveolares após o tratamento ortodôntico, podiam contribuir para a recidiva vertical anterior. Observaram que, algum tempo após a contenção, alguns pacientes apresentaram recidiva da mordida aberta. Concluíram que esses pacientes apresentavam maior crescimento alveolar e sutural da maxila, juntamente com maior crescimento alveolar da mandíbula do que da altura facial posterior, como também uma maior rotação da mandíbula para baixo, sendo a extrusão dos dentes posteriores a maior causa da recidiva da mordida aberta.

Ao estudar os fatores que levam à recidiva após o tratamento da mordida aberta, STRAUB ${ }^{141}$, em 1960 e GARLINER ${ }^{54}$, em 1980, afirmaram que os hábitos de sucção digital ou a interposição lingual causam a recidiva da mordida aberta; já SUBTELNY; SUBTELNY ${ }^{144}$, em 1973, concluíram, em uma excelente pesquisa, que a atividade muscular da língua é mantida principalmente pela forma do arco, enquanto outros afirmam ${ }^{66,83,118}$ que os efeitos do crescimento podem alterar as mudanças conseguidas com 0 tratamento. BJÖRK ${ }^{17}$, em 1963, após um estudo longitudinal em humanos, concluiu que o crescimento dos côndilos pode ser detectado em algumas pessoas mesmo após os 20 anos.

Estudando a estabilidade 10 anos pós-contenção, de 41 casos de mordida aberta, tratados ortodonticamente, LOPEZ-GAVITO et al. ${ }^{81}$ em 1985 , 
tiveram como objetivos: 1) comparar cefalometricamente os pacientes com mordida aberta e os que apresentavam uma oclusão normal; 2) avaliar as mudanças que ocorreram durante e após o tratamento da mordida aberta; 3) pesquisar se há possibilidades de prever a recidiva desses casos tratados, por meio de medidas cefalométricas. Analisaram as alterações ocorridas por computador, utilizando radiografias cefalométricas e modelos pré-tratamento, pós-tratamento e a longo prazo, concluindo que mais de $35 \%$ dos pacientes tratados demonstraram uma mordida aberta pós-contenção de $3 \mathrm{~mm}$ ou mais, com altura dentária ântero-inferior diminuída, altura facial ântero-superior diminuída, altura facial ântero-inferior aumentada e altura facial posterior diminuída, concluindo também que nenhuma medida cefalométrica pode ser confiável em prever a estabilidade pós-tratamento.

Estudando a estabilidade da mordida aberta, após a terapia com grade palatina, HUANG et al. $^{63}$, em 1990, coletaram uma amostra de 33 pacientes, dos quais 26 apresentavam-se em fase de crescimento e 7 sem crescimento. Após avaliação cefalométrica, analisaram que houve um aumento significante na sobremordida para ambos os grupos durante o tratamento. $O$ grupo sem crescimento também mostrou um aumento significante na sobremordida durante o período pós-tratamento. Na fase pós-tratamento (1 a 7 anos pós-tratamento), $17,4 \%$ da amostra em crescimento e $0 \%$ da amostra sem crescimento exibiram recidiva. No entanto, todos os pacientes que atingiram uma sobremordida positiva durante o tratamento mantiveram uma sobremordida positiva pós-tratamento. Desta forma, concluíram que os pacientes que alcançaram uma sobremordida positiva, tratados com a grade, têm uma boa chance de manter essa correção após o tratamento ortodôntico ser finalizado, o que ocorreu em ambos os grupos de pacientes, e a razão para essa grande estabilidade provavelmente se deve à modificação da postura lingual.

Segundo GOTO $^{56}$, em 1994, a falta de estabilidade dos dentes anteriores extruídos é amplamente reconhecida como uma das causas da recidiva da mordida aberta anterior. A falta de estabilidade da mordida aberta posterior é normalmente associada aos hábitos e as desordens funcionais, 
incluindo a interposição lingual durante a deglutição. E que, no adulto, as desordens funcionais freqüentemente persistem indefinidamente após o tratamento ortodôntico, sendo necessário, em tais pacientes, o uso indefinido de contenção. E de acordo com alguns autores ${ }^{49,61,121}$, a estabilidade da mordida aberta depende principalmente da correção da interposição lingual com uma terapia miofuncional associada a uma boa técnica ortodôntica e aparelhos contensores após o tratamento.

O tratamento da mordida aberta anterior pela técnica Edgewise, modificada com alças (MEAW), foi analisado cefalometricamente por $\mathrm{CHANG}^{25}$, em 1999, que utilizou uma amostra composta de 16 adultos jovens, e um grupo-controle de 58 adultos jovens, que tinha um perfil agradável e oclusão normal, sem nunca ter sido tratados ortodonticamente ou proteticamente. O grupo-controle foi subdividido pela relação cefalométrica vertical, de forma que, 40 adultos jovens com o perfil facial vertical, apresentavam-se dentro da proporção normal do padrão coreano, sendo classificados como grupo 1, e 18 pacientes, com padrão facial vertical acentuado, mas com oclusão normal, foram classificados como grupo 2. As mudanças no tratamento foram observadas, principalmente na região dentoalveolar, nos planos oclusais superior e inferior, acompanhadas por verticalização dos dentes posteriores, por meio do movimento de inclinação distal da dentadura permanente. Após o término do tratamento, houve uma tendência das características estruturais, do grupo de mordida aberta, a aproximar-se daquelas do grupo de oclusão normal, e concluiu que as alterações do tratamento da mordida aberta com a técnica "MEAW"' são semelhantes aquelas encontradas, no mecanismo compensatório dentoalveolar natural.

Com o objetivo de avaliar os efeitos da mecânica "multiloop", nos tratamentos de mordida aberta, $\mathrm{KIM}^{72}$, em 2000, observou, dois anos após 0 término dos tratamentos, a sua estabilidade, por meio de cefalogramas laterais, verificando se houve alterações esqueléticas, estéticas e dentoalveolares. Concluiu que: 1) a mordida aberta foi corrigida pela extrusão dos dentes anteriores e pelo movimento de verticalização dos dentes posteriores; 2) houve 
alterações significantes nas medidas esqueléticas do grupo em crescimento, a altura facial ântero-inferior, a anterior total e a póstero-inferior aumentaram. $\mathrm{O}$ plano palatino moveu anteriormente para baixo e o ângulo goníaco diminuiu. Não existiu nenhuma mudança significante nas variáveis esqueléticas do grupo sem crescimento, ocorrendo retração do lábio superior dos grupos com e sem crescimento. 4) esse tipo de mecânica mostrou-se muito estável, de forma que a recidiva da mordida aberta após esse período foi de $0,23 \mathrm{~mm}$ no grupo sem crescimento e $0,35 \mathrm{~mm}$ no grupo em crescimento, não sendo estatisticamente significante.

Como visto no tópico anterior, os casos com altura facial excessiva, na fase de dentadura permanente, normalmente estão associados a mordidas abertas também excessivas, devendo-se tratar com cirurgia ortognática associada ao tratamento ortodôntico, possuindo também além dos benefícios alguns riscos, como, paralisia labial, parestesia facial, hemorragia, infecção e sintoma articulares pós-cirúrgico. Para equilibrar os riscos com os benefícios, a estabilidade da correção cirúrgica devia ser avaliada minuciosamente. Apesar de alguns estudos relatarem resultados favoráveis, DENISON; KOKICH; SHAPIRO ${ }^{37}$, em 1989, após avaliação de radiografias cefalométricas laterais, em 28 pacientes, com mordida aberta, tratados com osteotomias Le Fort I para reposicionar a maxila, observaram que 42,9\% recidivaram, demonstrando-se clinicamente e estatisticamente significante, havendo aumento na altura facial anterior, erupção dos molares superiores e diminuição no "overbite" póstratamento, concluindo que os dados deste estudo sugerem que a instabilidade em pacientes com mordida aberta após o tratamento cirúrgico, deve-se a alterações dentoalveolares e não a alterações esqueléticas. Ainda avaliando a estabilidade cirúrgica, ARPORNMAEKLONG; HEGGIE ${ }^{10}$, em 2000, estudaram cefalometricamente a estabilidade do tratamento da mordida aberta com 0 reposicionamento cirúrgico maxilar, utilizando a fixação interna rígida após um tempo médio de 22,9 meses, com uma amostra de 37 pacientes sem crescimento, numa idade média de 21,7 anos, dividindo-se em dois grupos: grupo A (17 pacientes), em que se realizou avanço maxilar e reposicionamento superior da espinha nasal posterior e grupo B (20 pacientes), o mesmo que o grupo A, como também avanço mandibular, sem alteração significante no 
sentido vertical. Todos os pacientes, no início do tratamento, apresentaram uma mordida aberta com, no mínimo $1 \mathrm{~mm}$, quando medida da borda incisal do incisivo superior à borda incisal do inferior, perpendicularmente ao plano oclusal. Após o período estudado, concluíram que o reposicionamento superior da porção posterior da maxila, utilizando a fixação rígida, demonstrou ser um procedimento estatisticamente estável, enquanto que a estabilidade da correção da mordida aberta juntamente com o retrognatismo mandibular, depende grandemente da estabilidade do avanço mandibular que também se apresenta estritamente relacionada a uma favorável adaptação neuromuscular da nova posição, apresentando uma recidiva do avanço mandibular de $15 \%$ no grupo B, e, para se conseguir esta adaptação neuromuscular favorável, devese seguir cuidadosamente a descompensação e o alinhamento ortodôntico précirúrgico.

Ao avaliar a estabilidade do tratamento ortodôntico fixo, para correção da mordida aberta, PARRA ${ }^{108}$, em 2000, estudou cinco anos pós-contenção de 20 casos de pacientes portadores de mordida aberta anterior maior ou igual a $3 \mathrm{~mm}$, que foram tratados com a mecânica ortodôntica fixa, "edgewise" convencional, concluindo que $70 \%$ dos casos mantiveram a correção obtida com o tratamento cinco anos após a contenção. E comparando os casos com e sem extração dentária, observou que $63 \%$ dos casos tratados sem extração e $75 \%$ dos casos com extrações, seja de primeiros pré-molares, segundos prémolares ou primeiros molares permanentes, apresentaram estabilidade do tratamento após esse período. Dessa forma, concluiu que: 1) a mordida aberta anterior foi reduzida significantemente, como resultado da terapia aplicada, com significante estabilidade na relação maxilomandibular, no sentido vertical, após a contenção ter sido retirada; 2) a relação esquelética e dentária foram alteradas, significativamente na maioria dos casos, indicando uma rotação da maxila no sentido horário e da mandíbula no sentido anti-horário.

Ao estudar a importância das forças oclusais durante o tratamento da mordida aberta, ALEXANDER ${ }^{3}$, em 2000, concluiu que melhor tipo de contenção para mordida aberta anterior, é uma placa de acrílico superior com um orifício para atuar como um recordatório do posicionamento lingual. 
Explicou que o paciente deve ser instruído a colocar a ponta da língua no orifício, pressionando-o durante a deglutição, como também ao dormir. E quanto à estabilidade a longo prazo, o mesmo relatou que depende de uma correta posição dos dentes de acordo com o padrão esquelético de cada paciente e, principalmente, com estabelecimento de um padrão funcional muscular normal. 
3. Proposição 


\section{PROPOSIÇÂO}

Pela avaliação cefalométrica em norma lateral, das fases inicial, final e 5 anos pós-tratamento ortodôntico, de jovens com mordidas abertas anteriores, de ambos os sexos, com idade variando entre 10,08 a 16,5 anos, durante a fase de dentadura permanente, que se submeteram a tratamento ortodôntico corretivo, com extrações, temos como objetivos analisar:

- As características cefalométricas dos pacientes com mordida aberta em relação a um grupo controle sem tratamento, apresentando más oclusões de Classe I e II, em ambos os grupos;

- A correção da mordida aberta anterior após o tratamento ortodôntico fixo com extrações;

- A estabilidade da mordida aberta anterior cinco anos após o tratamento ortodôntico fixo com extrações;

- A correlação entre a recidiva e os fatores esqueléticos e/ou dentários. 


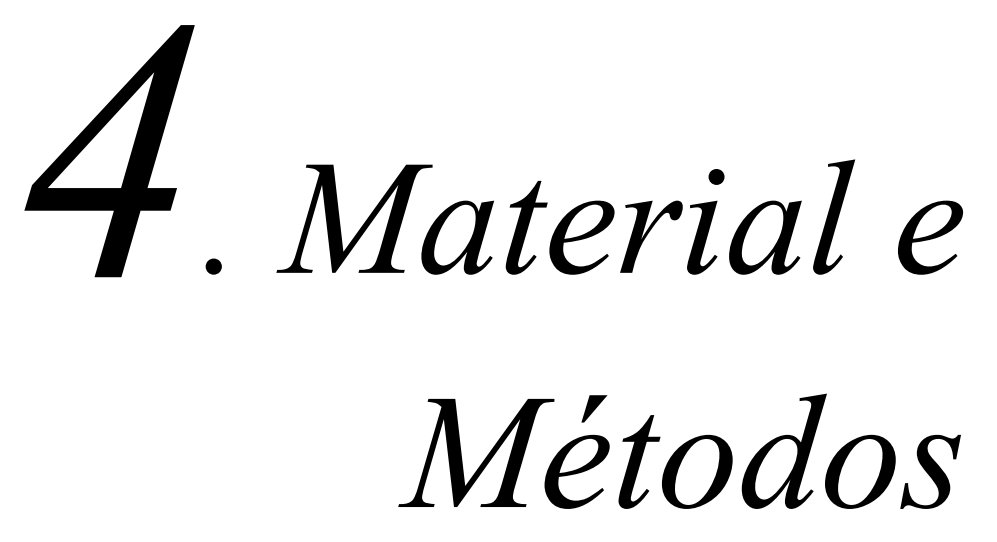




\section{4- MATERIAL E MÉTODOS}

\subsection{Material}

\subsubsection{Obtenção da amostra}

A amostra para este estudo foi obtida a partir de uma seleção realizada no Departamento de Odontopediatria, Ortodontia e Saúde Coletiva da Faculdade de Odontologia de Bauru-USP. Constituiu-se de 31 pacientes de ambos os gêneros que preencheram os seguintes requisitos: (1) idade média no início do tratamento de 13,22anos, variando entre 10,08 a 16,5anos; (2) mordida aberta anterior maior ou igual a $1 \mathrm{~mm}$, avaliada clinicamente pelo modelo de estudo, apresentando ainda dentadura permanente com más oclusões de classe I e II; (3) todos se submeteram a tratamento ortodôntico fixo, por meio da técnica "edgewise" simplificada, com extrações dentárias.

Para se observar as características cefalométricas iniciais desta amostra, comparou-se com um grupo-controle, apresentando 15 pacientes com más oclusões de Classe I e II, com idade média de 13 anos, que não se submeteram a tratamento ortodôntico. Esses pacientes foram selecionados do Atlas de Crescimento Craniofacial da Faculdade de Odontologia de Bauru USP, criado por MARTINS, et al $^{85}$., em 1998, com o objetivo de oferecer aos clínicos e pesquisadores do Brasil, uma descrição estatística de um amplo segmento de dados craniofaciais auferidos de estudo longitudinal, por meio de telerradiografias tomadas anualmente dos 6 aos 18 anos. 


\subsection{Métodos}

Do grupo experimental foram obtidas três telerradiografias, em norma lateral, de cada paciente selecionado, realizadas nas seguintes fases: no início do tratamento (T1), imediatamente após o tratamento terminado (T2) e após cinco anos do tratamento terminado (T3), totalizando-se uma amostra de 93 radiografias.

As telerradiografias foram realizadas em diferentes centros de radiologia, utilizando-se aparelhos regulados para uma exposição de $80 \mathrm{KVp}$, $10 \mathrm{~mA}$, com uma distância focal de $152 \mathrm{~cm}$ e tempo de exposição de 1,3 segundos. A cabeça do paciente foi posicionada no cefalostato, sendo o mesmo orientado para ficar com os lábios em posição de repouso e em máxima intercuspidação habitual. A mesma sistemática foi utilizada para aqueles que foram radiografados posteriormente.

Realizou-se o seguinte cálculo para se obter a porcentagem de magnificação de cada aparelho cefalométrico:

$$
M=\underline{b-a}
$$

a

$M=$ porcentagem de magnificação;

$a$ = distância real entre as olivas do cefalostato;

b = distância entre as olivas do cefalostato na imagem da telerradiografia.

Os diferentes tipos de aparelhos apresentaram porcentagens distintas de magnificação que variou em 6; 7,9 e 9,8\% 


\subsubsection{Traçados e Medição das Telerradiografias}

Sobre cada telerradiografia, adaptou-se uma folha de papel de poliéster "utraphan", com $17,5 \mathrm{~cm}$ de comprimento por $17,5 \mathrm{~cm}$ de largura e $0,07 \mathrm{~mm}$ de espessura. Procedeu-se o traçado dos cefalogramas em uma sala escurecida, com o auxílio de um negatoscópio, emoldurado com cartolina preta, expondose apenas a área correspondente ao desenho anatômico. Para a elaboração do cefalograma, utilizou-se de uma lapiseira com grafite preto de $0,3 \mathrm{~mm}$ de diâmetro, sendo realizado pelo pesquisador e conferidos, por um segundo examinador. Os pontos cefalométricos foram demarcados nos cefalogramas e computadorizados com o auxílio de uma mesa digitalizadora Numonics AccuGrid XNT, modelo A30TLF*, interligada a um microcomputador com processador Pentium ${ }^{\# \#}$. Os traçados, assim como as mensurações, foram realizados pelo programa de informática para Ortodontia Dentofacial Planner 7.02 \#\#\#. Devido à variação de aparelhos utilizados para se obter as telerradiografias iniciais e pós-tratamento, as mesmas apresentaram diferentes fatores de magnificação, determinados em 6\% (Setor de Radiologia da FOBUSP, até 1994 e CDB), 9,8\% (FOB-USP após 1994 e a Ortodiagnosis) e 7,9\% (SERDOC), os quais foram corrigidos pelo programa

\# Numonics Corporation - 101 Commerce Drive, Montgomerryville, PA 18963

\#\# Intel Corporation - 2200 Mission College Blvd., Santa Clara, CA EUA

\#\#\# Dentofacial Software Inc. - 100 Simcoe Street Suite 303, Toronto, Canada M5H $3 G 2$ 


\subsubsection{Delimitação do desenho anatômico}

O traçado cefalométrico compreendeu o contorno das seguintes estruturas anatômicas (Figura 1):

- ossos nasais e frontal

- sela túrcica

- osso esfenóide

- meato acústico externo

- cavidades orbitárias

- maxila

- mandíbula

- incisivos centrais superiores e inferiores

- primeiros molares permanentes superiores e inferiores

Para todas as estruturas bilaterais, foi efetuado o traçado médio 


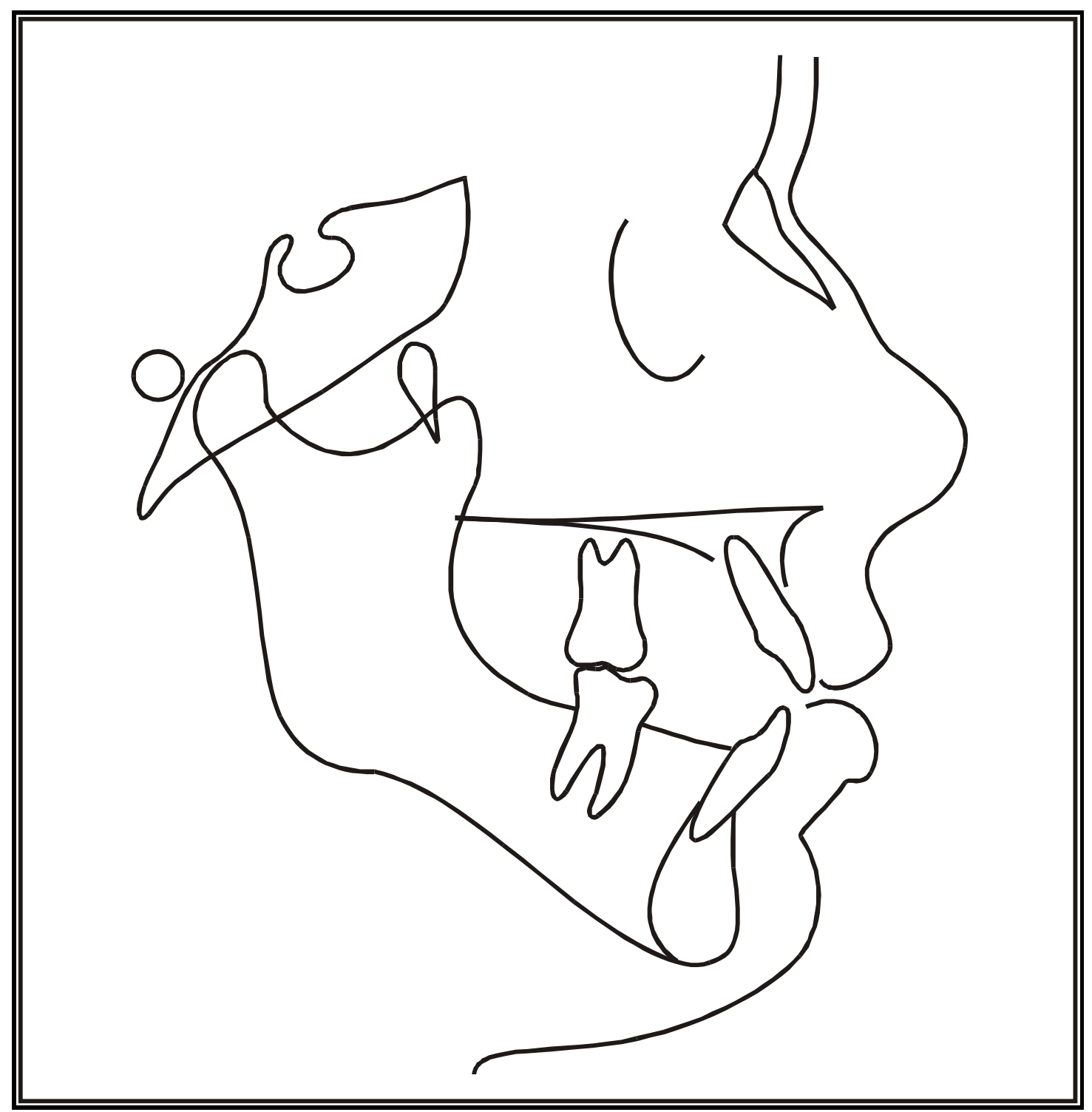

Figura 1 - Delimitação do desenho anatômico 


\subsubsection{Demarcação dos pontos cefalométricos}

Os pontos de referência anatômicos foram demarcados seguindo as epecificações de KROGMAN, SASSOUNI ${ }^{73}$, em 1957, MC NAMARA JUNIOR ${ }^{87}$, em 1984, e por STEINER ${ }^{140}$, em 1953.

1. S sela: túrcica: ponto central da concavidade óssea da sela túrcica;

2. N násio: ponto mais anterior da sutura frontonasal;

3. P pório: ponto mais superior do mesto acústico externo;

4. Or orbitário: ponto médio mais inferior da margem inferior;

5. ENA espinha nasal anterior: ponto mais anterior do assoalho da fossa nasal;

6. ENP ponto mais posterior do assoalho da fossa nasal;

7. A subespinhal: ponto mais profundo da concavidade anterior da maxila;

8. B supramentoniano: ponto mais profundo da concavidade anterior da mandíbula;

9. P pogônio: ponto mais proeminente do contorno anterior da sínfise mentoniana;

10. Gn gnátio: ponto construído, definido pela projeção da sínfise mentoniana, da bissetriz entre a borda inferior mandibular e a linha N-P;

11. Me mentoniano:ponto mais inferior do contorno da sínfisi mentoniana;

12. Co condílio:ponto mais póstero-superior do contorno do côndilo mandibular

13. Go ponto mais póstero-inferior da curva entre o corpo e o ramo mandibular;

14. BIS borda do incisivo superior: ponto mais inferior da borda incisal do incisivo superior 
15. AIS ápice do incisivo superior: ápice da raiz do incisivo central superior;

16. BII borda do incisivo inferior: ponto mais superior da borda incisal do incisivo central Inferior;

17. All ápice do incisivo inferior: ápice da raiz do incisivo central inferior

18. IDOM intercuspidação disto oclusal molar: ponto médio de intercuspidação das cúspides distais dos primeiros molares;

19. 6S- cúspide do molar superior: ponta da cúspide mesiovestibular do primeiro molar superior permanente;

20. 6l- cúspide do molar inferior- ponta da cúspide mesiovestibular do primeiro molar inferior permanente;

21. Ar- ponto localizado na interseção do contorno inferior do osso esfenóide com o contorno posterior do côndilo mandibular. 


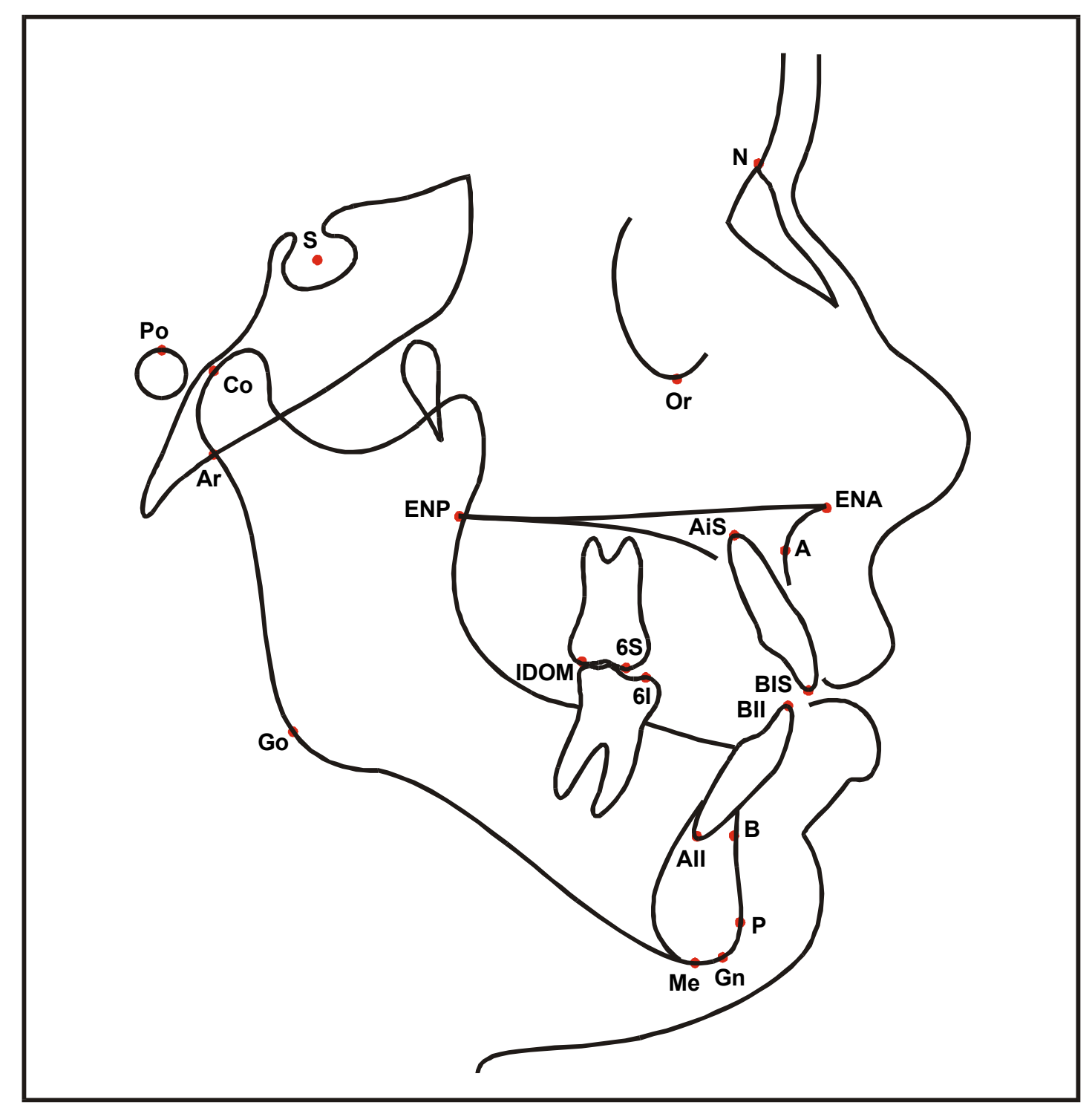

Figura 2 - Demarcação dos pontos cefalométricos. 


\subsubsection{Linhas e planos de referência}

1. Linha SN (base do crânio) - da sela túrcica ao násio;

2. Linha NA- do násio ao subespinhal;

3. Linha NB- do násio ao supramentoniano;

4. Linha BIS-AIS (longo eixo do incisivo superior) - da borda incisal ao ápice dos incisivos superiores;

5. Linha Bll-All (longo eixo do incisivo inferior) - da borda incisal ao ápice dos incisivos centrais inferiores;

6. Plano de Francfort (Po-Or) - do pório ao orbitário;

7. Plano palatino (PP) - da espinha nasal anterior à espinha nasal posterior;

8. Plano oclusal (PO) - da intercuspidação disto oclusal dos primeiros molares à borda incisal dos incisivos inferiores;

9. Plano mandibular (Go-Me) - do gônio ao mentoniano;

10. Plano mandibular (Go-Gn) - do gônio ao gnátio;

11. Plano Ar-Go - do articular ao gônio. 


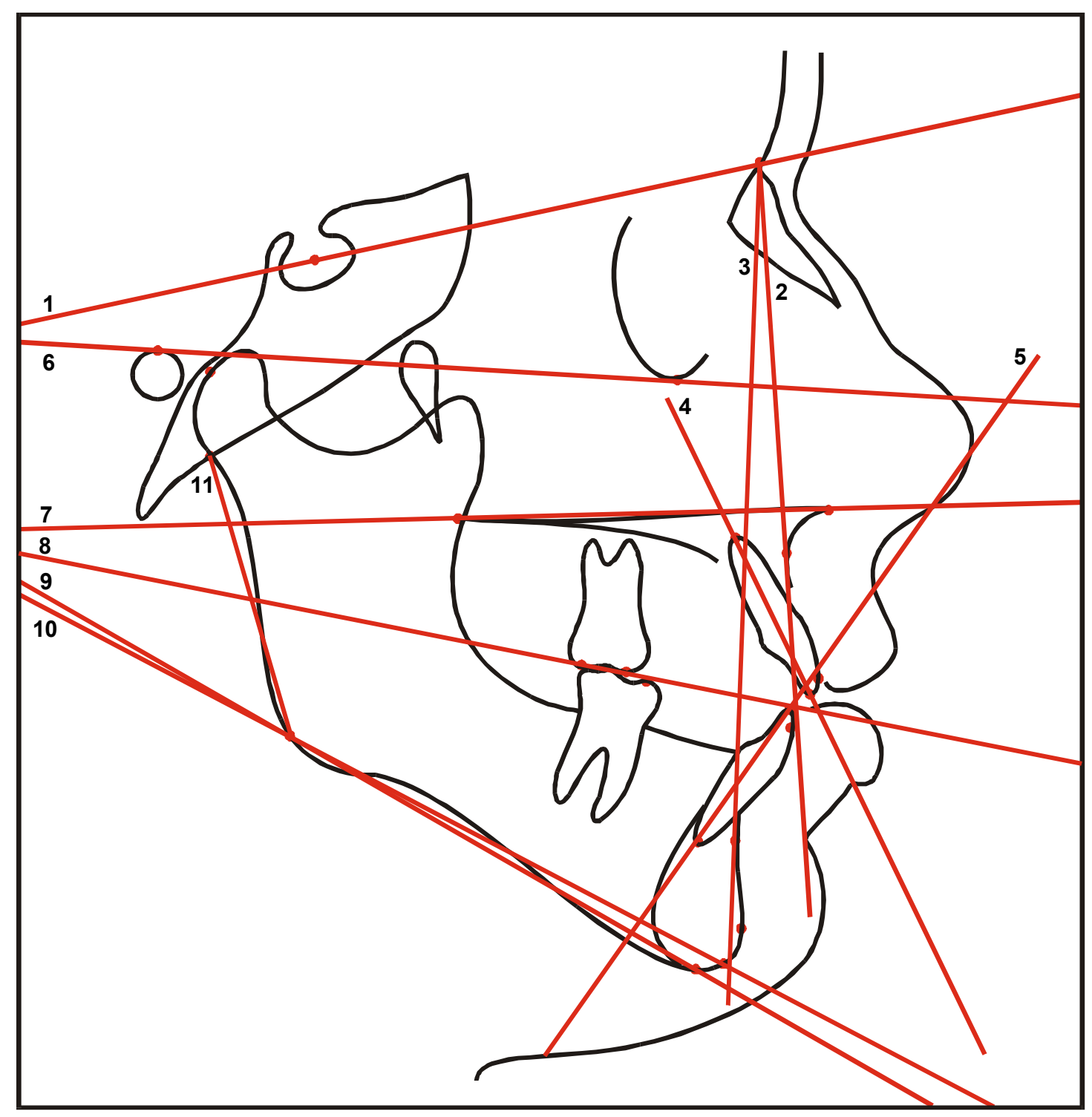

Figura 3 - Representação das linhas e planos de referência. 


\subsubsection{Grandezas angulares esqueléticas}

1. SN.GoGn - ângulo formado pela linha SN e o plano mandibular Go-Gn;

2. SN.PP - ângulo formado pela linha SN e o plano palatino;

3. Ar.GoMe - ângulo formado pelos planos Ar-Go e mandibular Go-Me;

4. SNA - ângulo formado pelas linhas SN e NA;

5. SNB - ângulo formado pelas linhas SN e NB;

6. ANB - diferença dos ângulos SNA e SNB;

7. FMA - ângulo formado pelos planos horizontal de Francfort e mandibular (GoMe), define basicamente a orientação do padrão de crescimento facial;

8. SN.Po - ângulo formado pela linha SN e pelo plano oclusal, relaciona o plano oclusal à linha SN. 


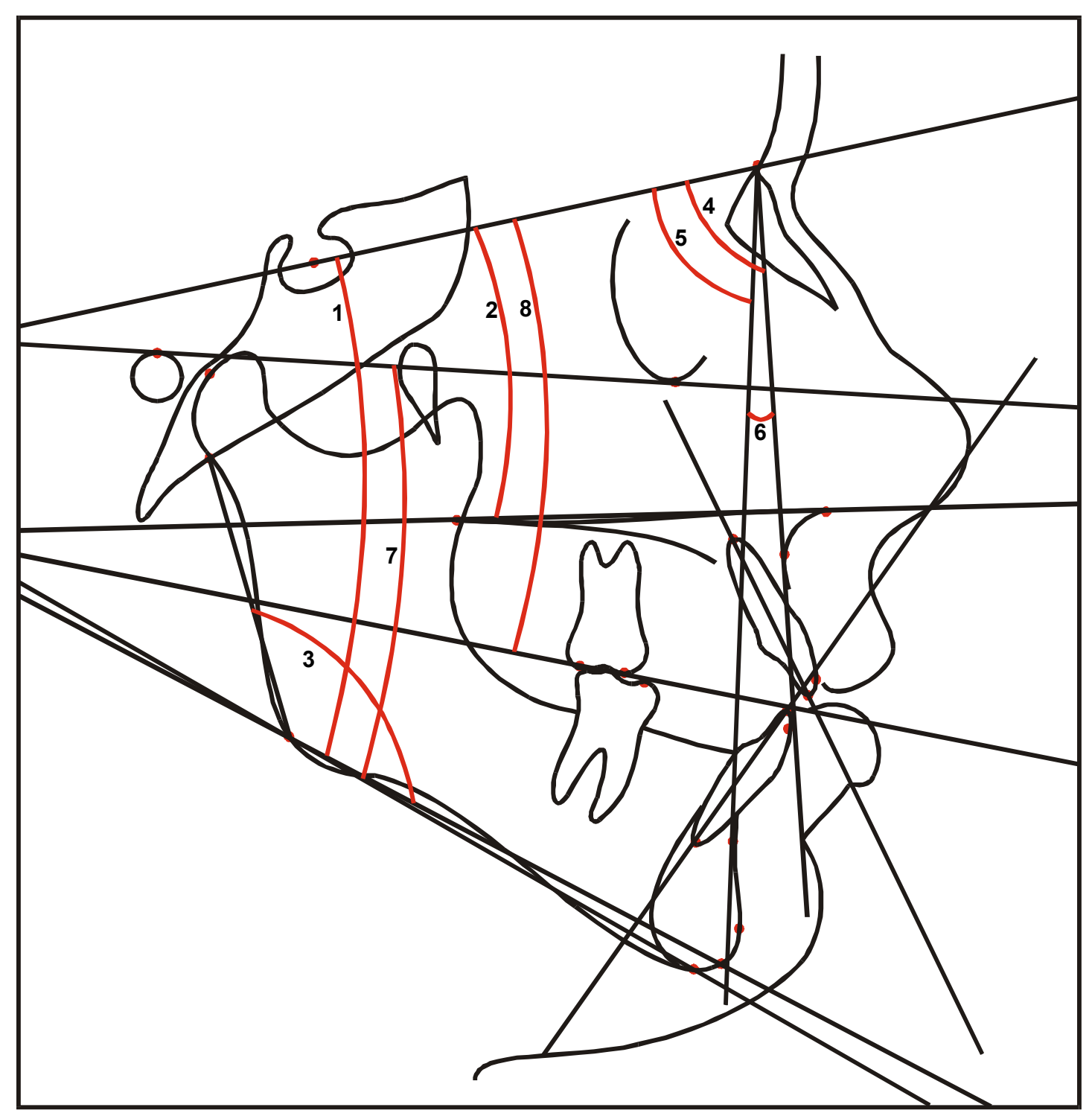

Figura 4 - Grandezas angulares esqueléticas 


\subsubsection{Grandezas lineares esqueléticas}

1. AFAI - distância vertical entre a espinha nasal anterior e o ponto mentonino, projetados perpendicularmente na linha N-perp;

2. AFAT - distância vertical entre o ponto $\mathrm{N}$ e o mentoniano, projetado perpendicularmene na linha N-perp;

3. Ar-Go - distância entre os pontos articular e gônio, mede o comprimento do ramo mandibular;

4. S-Go - distância entre os pontos sela e gônio, representando a altura facial posterior. 


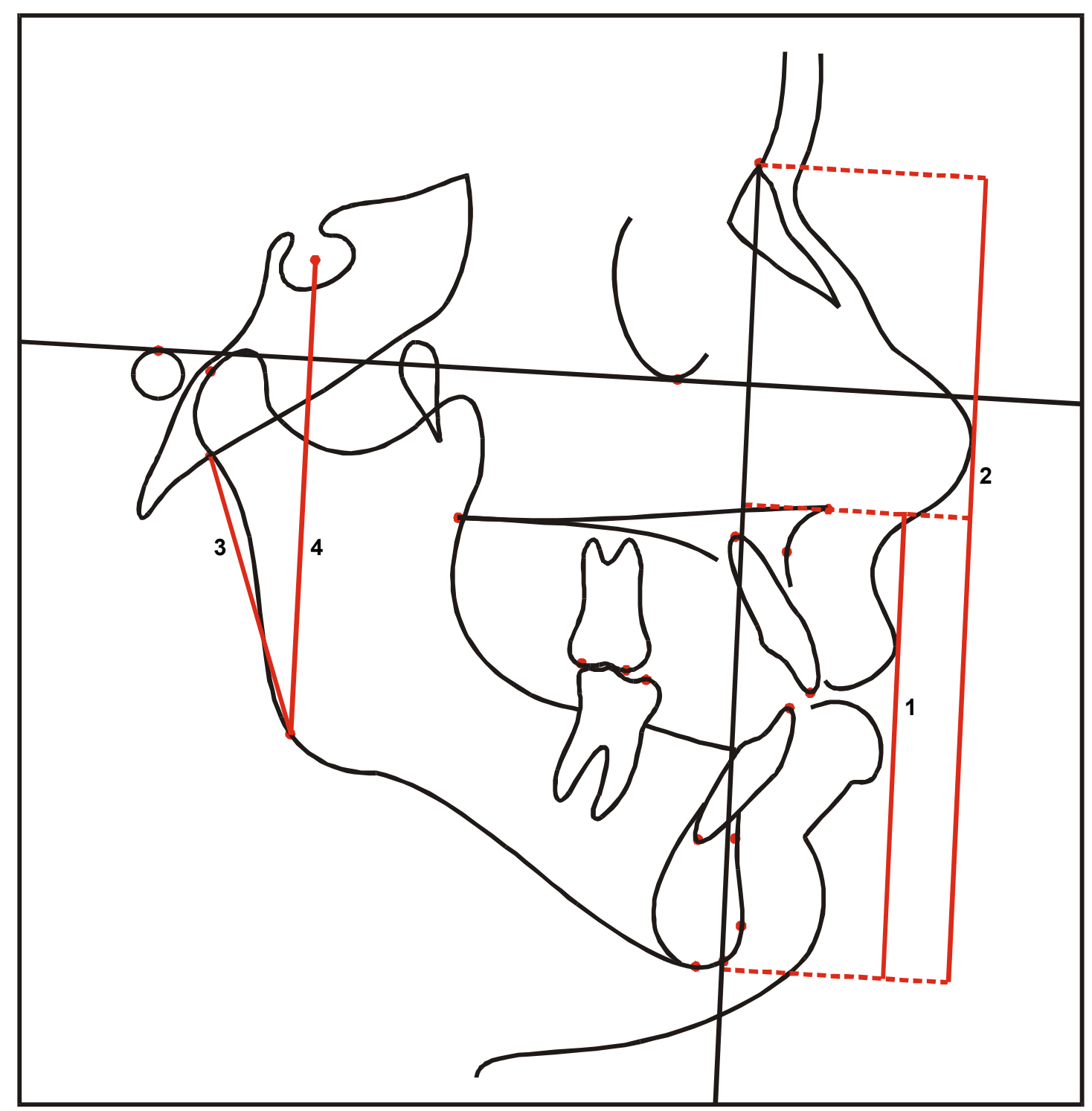

Figura 5 - Grandezas lineares esqueléticas 


\subsubsection{Grandezas dentárias angulares e lineares}

1. 1S.PP - ângulo formado pelo longo eixo do incisivo central superior e o plano palatino;

2. BIS-PP - distância entre a borda incisal do incisivo central superior e o plano palatino. Determina a altura do processo alveolar superior, em sua região anterior.

3. IMPA - ângulo formado pelo longo eixo do incisivo central inferior e o plano mandibular GoMe;

4. 1S.NA - ângulo entre o longo eixo do incisivo central superior e a linha NA. Define o grau de inclinação do incisivo central em relação à maxila e ao násio;

5. BIS-NA - distância entre a borda incisal do incisivo central superior e a linha NA. Relaciona a posição sagital do incisivo central superior em relação à maxila e ao násio, seu aumento indica uma protrusão do incisivo;

6. 1I.NB - ângulo entre o longo eixo do incisivo central inferior e a linha NB. Indica a inclinação deste em relação à mandíbula e o násio;

7. BII-NB - distância entre o ponto mais anterior da coroa do incisivo central inferior e a linha NB. Relaciona a posição sagital do incisivo inferior em relação à mandíbula e ao násio;

8. Bll-GoMe - distância entre a borda incisal do incisivo central inferior e o plano mandibular. Determina a altura do processo alveolar inferior, em sua região anterior;

9. 6S-PP - distância entre a cúspide mesiovestibular do primeiro molar superior e o plano palatino. Determina a altura do processo alveolar, em sua região posterior;

10. 6I-GoMe - distância entre a cúspide mesiovestibular do primeiro molar inferior e o plano mandibular. Determina a altura do processo alveolar inferior, em sua região posterior. 
11. BIS-Po- distância entre a borda incisal do incisivo central superior e o plano oclusal, mede a abertura da mordida anterior quando se apresenta negativa ou da sobremordida quando positiva.

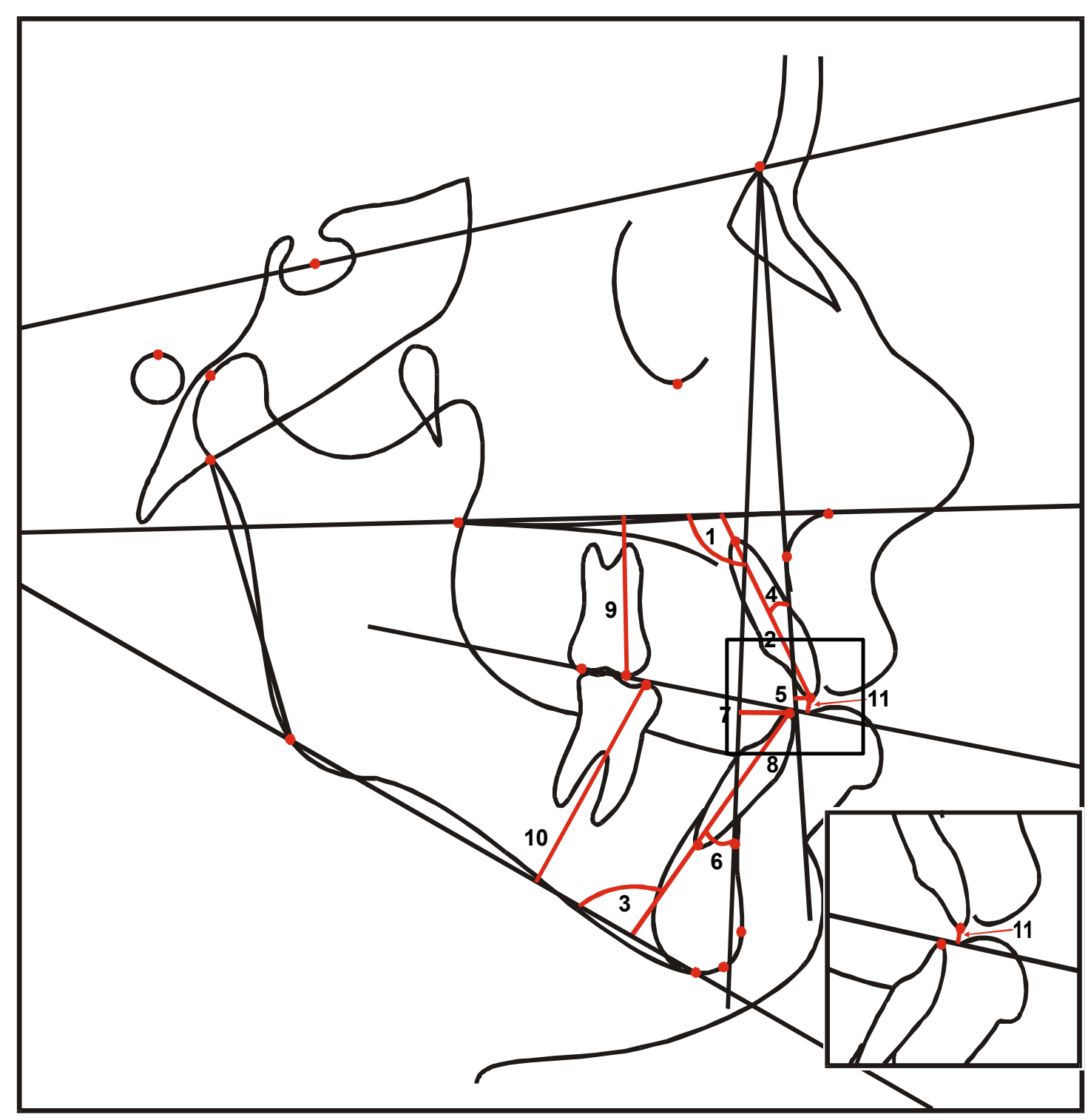

Figura 6 - Grandezas dentárias angulares e lineares 


\subsubsection{Descrição da mecânica utilizada nos pacientes dessa amostra}

Todos os pacientes dessa amostra receberam o mesmo tratamento ortodôntico corretivo. O aparelho fixo utilizado seguiu os princípios da técnica "edgewise" criado por Angle e, posteriormente, aperfeiçoada por Tweed, seu discípulo que introduziu a possibilidade das extrações dentárias. Visando a proporcionar uma simplificação no preparo de ancoragem e uma diminuição no tempo de tratamento, FREITAS; MARTINS ${ }^{51}$, em 1983, apresentaram um sistema de ancoragem composto pelo aparelho extrabucal, a placa lábio-ativa e o elástico de Classe III, desenvolvendo, dessa maneira, a técnica do Arco de Canto Simplificada.

Para a realização dos tratamentos, foram utilizados acessórios da técnica de "edgewise" com ranhura .022" X .028" (0,558 x 0,711 mm) (Figura 7). Foram empregados fios de aço inoxidável redondos de diâmetros de .016" $(0,406 \mathrm{~mm})$ ao $.020 "(0,508 \mathrm{~mm})$, para o nivelamento e elásticos 3/16 para o fechamento da mordida aberta anterior, utilizando-se também elásticos de Classe II. Após essa fase, utilizou-se fios retangulares .019" x .025" $(0,482 \times$ $0,635 \mathrm{~mm})$ e $.021 " x .025 "(0,533 \times 0,635 \mathrm{~mm})$ para a fase final de nivelamento, retração anterior, aplicação dos torques e intercuspidação.

Todos os tratamentos foram realizados com extrações de primeiros pré-molares, segundos ou de primeiros molares, incluindo-se os acessórios para a manutenção da ancoragem e correção da Classe II. Os aparelhos extrabucais utilizados no controle da ancoragem do arco superior foram os de tração média (IHG), com uma intensidade entre 400 e 600 gramas (Figura 8). O tempo médio de tratamento (T1-T2) foi de 2,46 anos e entre a fase final e cinco anos pós-tratamento, foi de 8,35 anos, com o mínimo de 17 e o máximo de 37,75 anos, na fase T3. Após o período de tratamento ativo, utilizou-se como contenção a placa removível de Hawley e a barra 3 × 3 no inferior. 

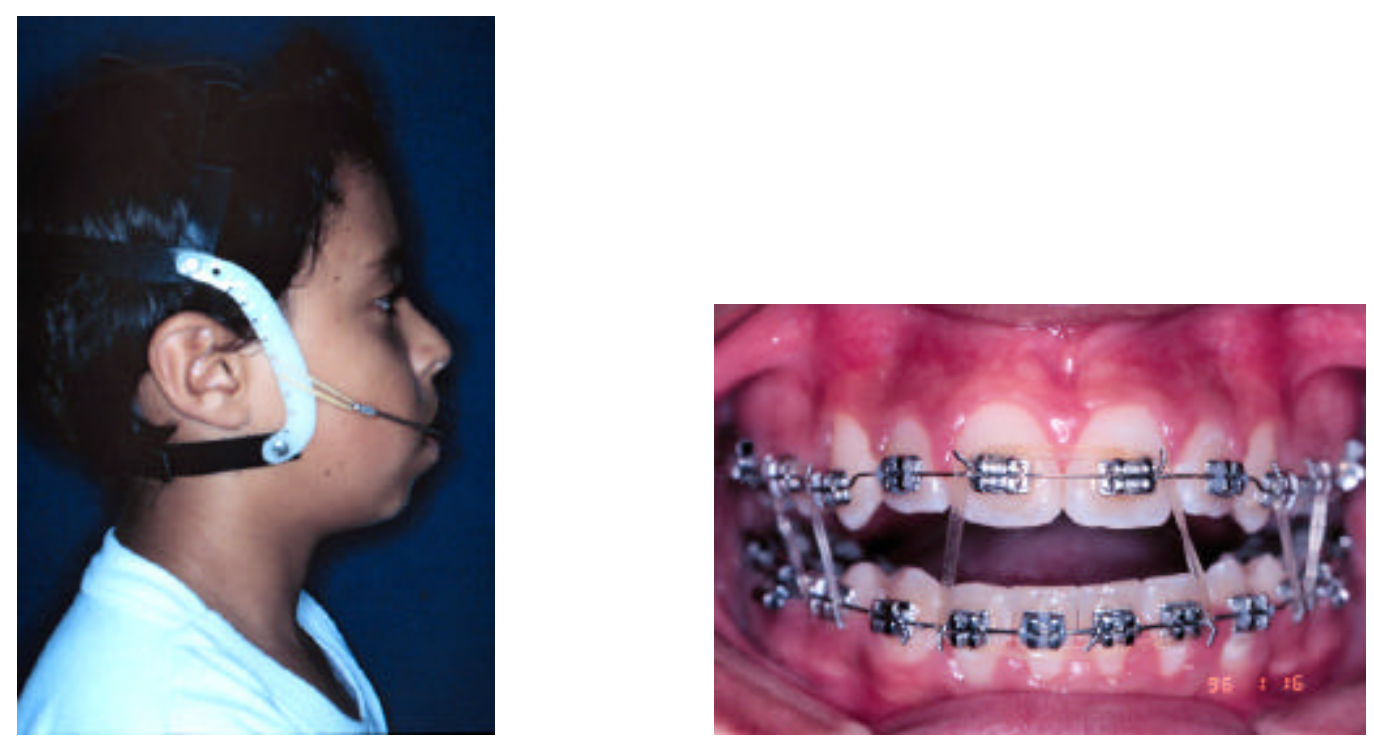

FIGURA 7 - Paciente da amostra, durante a fase do tratamento ortodôntico fixo, com elásticos verticais para o fechamento da mordida aberta, associado ao Aparelho extrabucal (IHG)
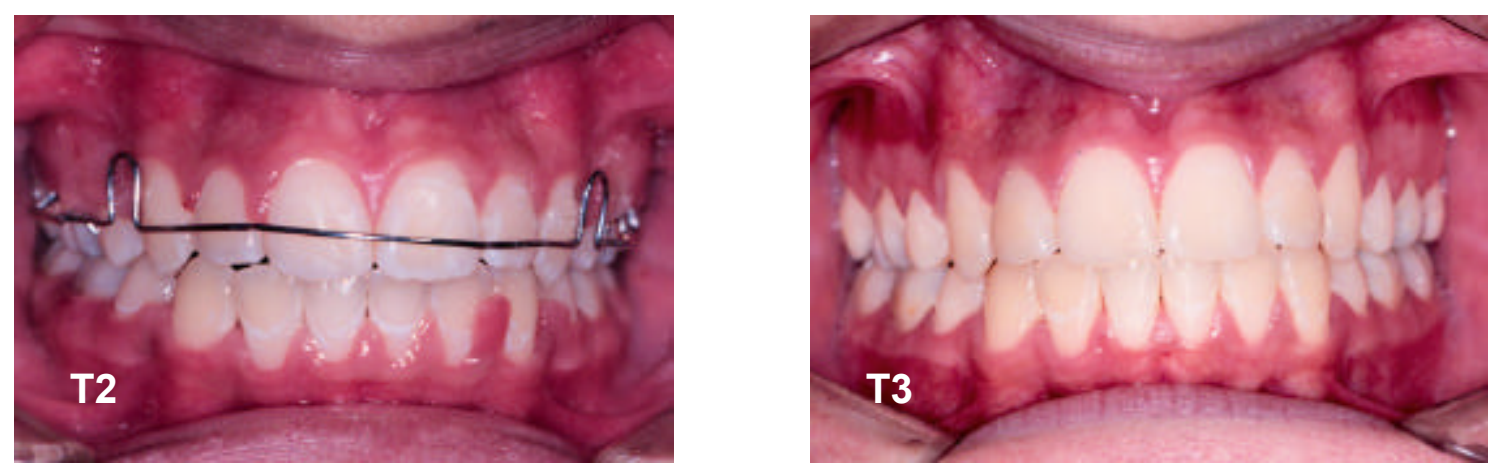

FIGURA 8 - Vista intrabucal frontal, durante a fase T2 e T3 


\subsubsection{Análise Estatística}

A análise estatística objetivou a comparação das médias das medidas cefalométricas iniciais desta amostra com as médias das medidas celométricas de um grupo controle, acompanhado longitudinalmente por MARTINS et $\mathrm{al}^{85}$, por meio do teste "t", não pareado.

Também se objetivou a comparação de três fases de um único grupo independente de pacientes, realizando-se o teste " $\mathrm{t}$ " de Student pareado para a comparação das diferenças entre as médias iniciais e finais e entre finais e cinco anos pós-tratamento. Em seguida, realizou-se o teste de Pearson, para correlacionar a recidiva obtida cinco anos após o tratamento com a quantidade de mordida aberta encontrada inicialmente. Como também, logo após o tratamento terminado, e com as outras medidas obtidas cinco anos após o término de tratamento. O valor crítico foi construído ao nível de significância de 0,05 para todas as análises empregadas.

Para se estabelecer um parâmetro clínico para o assunto proposto, definiu-se a "recidiva clinicamente significante" da mordida aberta anterior quando houve qualquer trespasse vertical negativo entre os incisivos superiores e inferiores, na fase T3, ou seja, após cinco anos do término de tratamento. Essa análise foi representada em forma de porcentagem avaliando os pacientes que apresentaram a "recidiva clinicamente significante" em relação ao total da amostra estudada. 


\subsubsection{Erro Metodológico}

Previamente à elaboração dos cefalogramas destinados à realização deste estudo, procurou-se determinar o erro metodológico. Para tanto, foram realizados os desenhos anatômicos e demarcação dos pontos de referência sobre 18 telerradiografias, selecionadas de forma aleatória, que posteriormente pertenceriam à amostra pesquisada. Em seguida, estes cefalogramas foram transferidos para o computador, onde se realizou as mensurações, obtendo-se os valores das grandezas cefalométricas.

Após um intervalo de 21 dias, realizou-se a obtenção dos cefalogramas de toda a amostra que se utilizou neste trabalho, incluindo uma nova realização dos traçados das 18 telerradiografias já obtidas previamente. Os cefalogramas foram tranferidos para o computador, permitindo a obtenção das mensurações.

\section{Erro Sistemático}

O erro sistemático foi obtido de acordo com o teste "t" de Student pareado, ao nível de significância de 5\%, comparando-se as médias de cada grandeza cefalométrica obtidas 21 dias previamente ao experimento, com valores obtidos durante as medições utilizadas neste estudo, nas mesmas 18 telerradiografias aleatoriamente selecionadas. 


\section{Erro Casual}

Obteve-se o erro casual dos valores obtidos em tempos distintos, de acordo com a fórmula proposta por DAHLBERG ${ }^{30}$, em 1940:

$$
E^{2}=\frac{\sum d^{2}}{2 n}
$$

na qual: "d" indica a diferença entre as mensurações de uma mesma variável e "n" indica o número de pares de cefalogramas comparados. 
5. Resultados 


\section{RESULTADOS}

O conjunto de planos e linhas de referência adotados permitiu a interpretação de 23 grandezas cefalométricas, sendo 12 angulares e 11 lineares. Tais grandezas possibilitaram a avaliação das alterações dentoesqueléticas na participação da recidiva da mordida aberta. Dividiu-se então os resultados em:

\section{Características cefalométricas iniciais (T1);}

Período pós-tratamento (T2);

Período cinco anos pós-tratamento (T3).

Recidiva clínica

Erro metodológico

\subsection{Características cefalométricas iniciais (T1)}

Após a comparação das médias das grandezas iniciais dos pacientes desta amostra com o grupo-controle com más oclusões de Classe I e II , pertencentes ao Atlas de Crescimento Craniofacial ${ }^{85}$, da Disciplina de Ortodontia da Faculdade de Odontologia de Bauru - USP (Tabela 1), observouse que a maxila não apresentou alteração estatística significante, demonstrando apresentar-se bem posicionada em relação à base do crânio, com o SNA apresentando-se normal, enquanto o SNB, apresentou-se diminuído, sem significância estatística $(P>0,05)$, demonstrando que a mandíbula nos pacientes com mordida aberta encontra-se um pouco retruída em relação à base do crânio. $O$ plano mandibular apresentou-se estatisticamente $(P<0,05)$ inclinado no sentido horário, quando relacionado à base do crânio como demonstra a medida SN.GoGn, que se apresentou 
aumentada no grupo de mordida aberta. Como também o ângulo do plano mandibular Ar.GoGn comportou-se semelhantemente.

Nesse mesmo grupo, o plano palatino apresentou-se anteriormente inclinado para cima, em relação à base do crânio, resultando em diminuição significante $(P<0,05)$ do ângulo SN.PP, embora esta medida apresente um dimorfismo de gênero estatisticamente significante $(P<0,01)$, apresentado no Atlas de crescimento. Enquanto o plano oclusal de Downs em relação à base do crânio apresentou uma inclinação, não estatisticamente significante $(p>0,05)$ no sentido horário, com o ângulo SN.Po, apresentando um aumento não significante.

A altura facial anterior total (AFAT) e a posterior (S-Go) apresentaramse estatisticamente diminuídas $(P<0,05)$, com a altura do ramo mandibular (ArGo), apresentando-se estatisticamente menor $(P<0,05)$, enquanto a altura facial ântero-inferior (AFAI), apresentou um aumento não estatisticamente significante $(P>0,05)$ no grupo de mordida aberta do que no grupo controle.

Quanto às grandezas dentárias, as estruturas dentoalveolares também diferenciaram-se em relação ao grupo controle. A altura dentoalveolar dos incisivos inferiores (Bll-GoMe) e primeiros molares inferiores (6I-GoMe), apresentou-se estatisticamente diminuída $(P<0,05)$, enquanto os incisivos e molares superiores não apresentaram alteração das alturas dentoalveolares significantes $(P>0,05)$. Os incisivos superiores apresentaram-se estatisticamente $(P<0,05)$ inclinados para vestibular em relação à base do crânio e ao plano palatino e protruídos, quando relacionados com a base do crânio. Já os incisivos inferiores, quando relacionados ao plano mandibular e à base do crânio, não apresentaram alterações estatisticamente significantes $(P>0,05)$. Quanto ao posicionamento no sentido ântero-posterior, os incisivos apresentaram-se protruídos em relação à base do crânio. 
Tabela 1 - Comparação entre as medidas dentoesqueléticas do grupo experimental (T1) e do grupo controle (Atlas de Crescimento Craniofacial ${ }^{85}$ ).

\begin{tabular}{|c|c|c|c|c|c|c|}
\hline $\begin{array}{c}\text { Medidas } \\
\text { Cefalométricas }\end{array}$ & T1 & DP & $\begin{array}{c}\text { Medidas do } \\
\text { Atlas }\end{array}$ & DP & $\mathbf{T}$ & p \\
\hline SNA & 80,14 & 3,9 & 80,6 & 3,7 & 0,38 & 0,70 \\
\hline SNB & 76,38 & 3,6 & 77,9 & 3,4 & 1,4 & 0,15 \\
\hline ANB & 3,74 & 2,1 & 2,6 & 1,6 & 0 & 1 \\
\hline SN.GoGN & 39,1 & 4,1 & 34,9 & 4,6 & $-3,13$ & 0,00 \\
\hline FMA & 30,55 & 5 & 27,9 & 2,9 & $-1,86$ & 0,06 \\
\hline SN.PP & 7,71 & 3,3 & 11 & 2,8 & 3,32 & 0,00 \\
\hline Ar.GoMe & 130,06 & 4,4 & 124,2 & 5,7 & $-3,81$ & 0,00 \\
\hline SN.PO & 20,63 & 4,9 & 18,6 & 4,1 & $-1,34$ & 0,18 \\
\hline Ar-Go & 40,4 & 3,9 & 46,8 & 3,7 & 5,3 & 0,00 \\
\hline S-Go & 68,23 & 4,9 & 74,6 & 5,2 & 4,07 & 0,00 \\
\hline 1S.PP & 117,41 & 6,9 & 114,1 & 7,2 & $-1,4$ & 0,14 \\
\hline IMPA & 90,64 & 6,1 & 92,4 & 5,4 & 0,97 & 0,33 \\
\hline BIS-NA & 7,57 & 2,45 & 4 & 2,4 & $-4,63$ & 0,00 \\
\hline BII-NB & 6,52 & 1,5 & 4,6 & 1,3 & $-4,19$ & 0,00 \\
\hline 1S.NA & 29,55 & 5,6 & 22,3 & 6,8 & $-3,8$ & 0,00 \\
\hline 1I.NB & 28,17 & 5,4 & 26,1 & 4,1 & $-1,2$ & 0,21 \\
\hline 6S-PP & 23,93 & 2,4 & 23,3 & 2,2 & $-0,8$ & 0,41 \\
\hline 6I-GoMe & 29,6 & 2,0 & 32,5 & 2 , & 3,9 & 0,00 \\
\hline BIS-PP & 27,43 & 3,0 & 28,4 & 2,8 & 1,0 & 0,28 \\
\hline BII-GoME & 38,47 & 2,7 & 40,9 & 2,3 & 2,9 & 0,00 \\
\hline AFAT & 114,57 & 6,7 & 119,6 & 4,3 & 2,6 & 0,01 \\
\hline AFAl & 69,08 & 5,2 & 66,4 & 4,3 & $-1,67$ & 0,10 \\
\hline
\end{tabular}

Significante para $\mathrm{p} \quad 0,05$ 


\subsection{Período pós-tratamento (T1-T2)}

Comparando-se a fase inicial (T1) com a fase pós-tratamento (T2), como demonstrado na tabela 2, a grandeza angular esquelética SN.Po apresentou diminuição estatisticamente significante. Enquanto as grandezas lineares esqueléticas Ar-Go, S-Go, AFAT e AFAl apresentaram aumento estatisticamente significante. Quanto às alterações dentárias, as grandezas angulares 1S.PP, 1S.NA, IMPA e BII.NB apresentaram-se estatisticamente diminuídas, enquanto as lineares apresentaram aumento estatisticamente significante, com exceção das grandezas BIS-NA e BII-NB que diminuíram. A grandeza linear que representa o trespasse vertical, após a correção da mordida aberta (BIS-Po T2-T1) apresentou um aumento estatisticamente significante. 
Tabela 2 - Médias e desvio padrão das medidas cefalométricas iniciais (T1) e póstratamento (T2), bem como as diferenças estatísticas

\begin{tabular}{|c|c|c|c|c|}
\hline $\begin{array}{c}\text { MEDIDAS } \\
\text { CEFALOMÉTRICAS }\end{array}$ & $\begin{array}{c}\text { T1 } \\
X \pm D . P .\end{array}$ & $\begin{array}{c}\text { T2 } \\
X \pm D . P .\end{array}$ & $\begin{array}{l}\text { DIF. } \\
\text { ESTAT. }\end{array}$ & $\mathbf{P}$ \\
\hline SNA & $80,14 \pm 3,97$ & $79,72 \pm 3,30$ & $-0,42$ & ו \\
\hline SNB & $76,38 \pm 3,60$ & $76,31 \pm 3,52$ & $-0,07$ & 0,783886 \\
\hline ANB & $3,74 \pm 2,18$ & $3,41 \pm 2,47$ & $-0,33$ & $0,39064 \varsigma$ \\
\hline SN.GoGN & $39,10 \pm 4,16$ & $39,46 \pm 4,32$ & $-0,36$ & $0,23238 i$ \\
\hline FMA & $30,55 \pm 5,05$ & $31,47 \pm 5,17$ & $-0,92$ & $0,17724 \varepsilon$ \\
\hline SN.PP & $7,71 \pm 3,30$ & $7,97 \pm 3,09$ & $-0,26$ & $0,55770 x$ \\
\hline Ar.GoMe & $130,06 \pm 4,4 ! 5$ & $130,02 \pm 5,41$ & $-0,04$ & $0,94796 \epsilon$ \\
\hline SN.PO & $20,63 \pm 4,98$ & $17,06 \pm 3,93$ & $-3,57$ & 0,000001 \\
\hline Ar-Go & $40,40 \pm 3,92$ & $41,57 \pm 4,36$ & $-1,17$ & $0,00850 \epsilon$ \\
\hline S-Go & $68,23 \pm 4,94$ & $70,44 \pm 5,27$ & 2,21 & $0,00000^{\prime}$ \\
\hline 1S.PP & $117,41 \pm 6,9: 3$ & $109,33 \pm 11,1 ; 3$ & $-8,08$ & $0,00003 i$ \\
\hline IMPA & $90,64 \pm 6,10$ & $85,20 \pm 6,21$ & $-5,44$ & $0,00000 c$ \\
\hline 1V-NA & $7,57 \pm 2,45$ & $4,04 \pm 2,91$ & $-3,53$ & 0,00000 \\
\hline 1V-NB & $6,52 \pm 1,59$ & $5,66 \pm 1,35$ & $-0,86$ & 0,00114 \\
\hline 1S.NA & $29,55 \pm 5,67$ & $23,24 \pm 6,33$ & $-6,31$ & $0,00013 \varepsilon$ \\
\hline 1I.NB & $28,17 \pm 5,48$ & $23,10 \pm 5,10$ & $-5,07$ & $0,00000 c$ \\
\hline 6S-PP & $23,93 \pm 2,47$ & $25,72 \pm 2,64$ & 1,79 & $0,00001<$ \\
\hline 6I-GoMe & $29,60 \pm 2,06$ & $31,42 \pm 1,85$ & 1,82 & $0,00000 c$ \\
\hline BIS-PP & $27,43 \pm 3,04$ & $30,00 \pm 2,97$ & 2,57 & 0,000001 \\
\hline Bll-GoMe & $38,47 \pm 2,70$ & $40,15 \pm 2,54$ & 1,68 & 0,000001 \\
\hline AFAT & $114,57 \pm 6,71)$ & $118,30 \pm 7,05$ & 3,73 & 0,00000 \\
\hline AFAl & $69,08 \pm 5,22$ & $71,39 \pm 5,35$ & 2,31 & 0,00044 ؟ \\
\hline BIS-PO & $-2,73 \pm 1,80$ & $1,09 \pm 0,94$ & 3,82 & 0,00000 \\
\hline
\end{tabular}

Significante para $p \quad 0,05$. 


\subsection{Período cinco anos pós-tratamento (T3).}

Após a análise das alterações ocorridas entre a fase final com a fase controle (T2-T3), como demonstrado na tabela 3, observa-se que a recidiva da mordida aberta não foi significante $(P<0,05)$, apresentando, em porcentagem clínica, uma recidiva de 25,8\%, como demonstrado na tabela 7 , e na tabela 5 , as médias iniciais, finais e controle do trespasse vertical, observou-se que houve uma pequena diminuição do trespasse vertical T3-T2, porém a média continuou positiva. As grandezas esqueléticas angulares FMA e Ar.GoMe apresentaram diminuição e a linear AFAT, apresentou aumento estatisticamente significante $(P<0,05)$. Quanto às grandezas dentárias angulares IMPA, 1I.NB e lineares BII-NB, BIII-GoMe, 6S-PP e 6I-GoMe apresentaram aumento estatisticamente significante $(P<0,05)$. 
Tabela 3 - Médias e desvio-padrão das medidas cefalométricas, pós-tratamento (T2) e no mínimo, cinco anos pós-tratamento (T3), bem como as diferenças estatísticas.

\begin{tabular}{|c|c|c|c|c|}
\hline $\begin{array}{c}\text { MEDIDAS } \\
\text { CEFALOMÉTRICAS }\end{array}$ & $\begin{array}{c}\text { T2 } \\
\text { X } \pm \text { D.P. }\end{array}$ & $\begin{array}{c}\text { T3 } \\
X \pm D . P .\end{array}$ & $\begin{array}{c}\text { DIF. } \\
\text { ESTAT. }\end{array}$ & $\mathbf{P}$ \\
\hline SNA & $79,72 \pm 3,30$ & $79,38 \pm 3,63$ & $-0,33$ & 0,293793 \\
\hline SNB & $76,31 \pm 3,52$ & $76,07 \pm 3,79$ & $-0,24$ & 0,319108 \\
\hline ANB & $3,41 \pm 2,04$ & $3,30 \pm 2,29$ & $-0,11$ & 0,707566 \\
\hline SN.GoGN & $39,46 \pm 4,32$ & $38,90 \pm 4,51$ & $-0,56$ & 0,144621 \\
\hline FMA & $31,47 \pm 5,17$ & $30,17 \pm 4,59$ & $-1,29$ & 0,017777 \\
\hline SN.PP & $7,97 \pm 3,09$ & $8,10 \pm 3,45$ & 0,12 & 0,633317 \\
\hline Ar.GoMe & $130,02 \pm 5,41$ & $128,16 \pm 5,4 €$ & $-1,86$ & 0,003343 \\
\hline SN.PO & $17,06 \pm 3,93$ & $16,44 \pm 4,29$ & $-0,61$ & 0,228076 \\
\hline Ar-Go & $41,57 \pm 4,36$ & $43,69 \pm 3,46$ & 2,11 & 0,001763 \\
\hline S-Go & $70,44 \pm 5,27$ & $72,40 \pm 5,19$ & $-1,96$ & 0,002685 \\
\hline 1S.PP & $109,33 \pm 11,1=$ & $111,38 \pm 7,4 €$ & 2,05 & 0,241477 \\
\hline IMPA & $85,20 \pm 6,21$ & $88,00 \pm 5,42$ & 2,79 & 0,001191 \\
\hline BIS-NA & $4,04 \pm 2,91$ & $5,21 \pm 2,62$ & 1,17 & 0,040000 \\
\hline BII-NB & $5,66 \pm 1,35$ & $6,21 \pm 1,53$ & 0,55 & 0,002062 \\
\hline 1S.NA & $23,24 \pm 6,33$ & $24,41 \pm 6,60$ & 1,17 & 0,243711 \\
\hline 1I.NB & $23,10 \pm 5,10$ & $25,05 \pm 4,29$ & 1,95 & 0,009646 \\
\hline 6S-PP & $25,72 \pm 2,64$ & $26,47 \pm 2,15$ & 0,75 & 0,036712 \\
\hline 6I-GoMe & $31,42 \pm 1,85$ & $32,40 \pm 1,86$ & 0,97 & 0,000030 \\
\hline BIS-PP & $30,00 \pm 2,97$ & $30,36 \pm 2,79$ & 0,36 & 0,144714 \\
\hline Bll-GoMe & $40,15 \pm 2,54$ & $40,74 \pm 2,59$ & 0,59 & 0,022880 \\
\hline AFAT & $118,30 \pm 7,05$ & $118,66 \pm 7,0 \varepsilon$ & 0,36 & 0,000023 \\
\hline AFAl & $71,39 \pm 5,35$ & $72,12 \pm 5,44$ & 0,73 & 0,092604 \\
\hline BIS-PO & $1,09 \pm 0,94$ & $1,02 \pm 1,62$ & $-0,06$ & 0,803535 \\
\hline
\end{tabular}

Significante para $P \quad 0,05$ 
Tabela 4- Trespasse vertical (BIS-Po) valor médio, mínimo, máximo e desvio-padrão

\begin{tabular}{|c|c|c|c|c|}
\hline \multicolumn{5}{|c|}{ Trespasse Vertical } \\
\hline & média & mínimo & máximo & Desvio padrão \\
\hline BIS-Po T1 & $-2,73$ & $-1,0$ & $-8,4$ & 1,80 \\
\hline BIS-Po T2 & 1,09 & 3,2 & $-0,7$ & 0,94 \\
\hline BIS-Po T3 & 1,02 & 5,10 & $-2,6$ & 1,62 \\
\hline
\end{tabular}

Quanto ao teste do coeficiente de correlação de Pearson, quando se comparou a recidiva verificada cinco anos pós-tratamento (T3) com a abertura da mordida (T1), observou-se com o valor do " $r$ " positivo ( $r=0,63)$, uma correlação diretamente proporcional, em que quanto menor a abertura da mordida (T1), menor será a alteração deste trespasse na fase controle (T3), (Tabela-5).

Quando se comparou o trespasse vertical obtido logo após o tratamento (T2) com a alteração do trespasse vertical, na fase controle (T3), verificou-se com o valor do "r" negativo $(r=-0,67)$, uma correlação inversamente proporcional, em que quanto maior o trespasse obtido após a fase (T2), menor será a alteração do trespasse após a fase (T3), (Tabela-5).

Ao correlacionar-se a recidiva após, no mínimo, cinco do término de tratamento (T3) com o restante das medidas cefalométricas, apenas duas (SN.Po e BIS-PP) apresentaram correlação estatisticamente significante com a alteração do trespasse, demonstrando que, quanto menor a alteração do ângulo SN.Po (T3) maior será a alteração do trespasse vertical na fase T3 e quanto menor a alteração da altura dentoalveolar dos incisivos superiores, menor será a alteração do trespasse vertical na fase T3; Entretanto devido ao valor do "r" $<0,8$, esta correlação torna-se inexpressiva por apresentar-se em apenas $14 \%$ dos casos (Tabela -5 ). 
Tabela 5- Teste de correlação de Pearson

Alteração do trespasse $X$ Trespasse vertical inicial (BIS-Po T3-T2 X BIS-Po T1)

Alteração do trespasse $X$ Trespasse vertical pós correção (BIS-Po T3-T2 X BIS-Po T2-T1)

Alteração do trespasse $X$ Alterações das variáveis após, no mínimo, 5 anos de tratamento (Medida T3-T2 X BIS-Po T3-T2)

\begin{tabular}{|c|c|c|}
\hline Medida & $(r)$ & $\mathbf{P}$ \\
\hline BIS-Po T3-T2 X BIS-Po T1 & 0,63 & 0,00 \\
\hline BIS-Po T3-T2 X BIS-Po T2-T1 & $-0,67$ & 0,00 \\
\hline Medidas T3-T2 X BIS-Po T3-T & $(r)$ & $\mathbf{P}$ \\
\hline SNA & 0,05 & 0,75 \\
\hline SNB & $-0,30$ & 0,10 \\
\hline ANB & 0,30 & 0,09 \\
\hline SN.GoGN & $-0,12$ & 0,49 \\
\hline FMA & 0,02 & 0,89 \\
\hline SN.PP & 0,32 & 0,07 \\
\hline Ar.GoMe & $-0,29$ & 0,11 \\
\hline SN.PO & $\begin{array}{l}-0,38 \\
\end{array}$ & 0,03 \\
\hline Ar-Go & 0,24 & 0,19 \\
\hline S-Go & 0,03 & 0,85 \\
\hline 1S.PP & $-0,30$ & 0,85 \\
\hline IMPA & $-0,09$ & 0,61 \\
\hline BIS-NA & $-0,31$ & 0,08 \\
\hline BII-NB & $-0,12$ & 0,50 \\
\hline 1S.NA & $-0,31$ & 0,08 \\
\hline 1I.NB & $-0,25$ & 0,17 \\
\hline 6S-PP & $-0,04$ & 0,81 \\
\hline 6I-GoMe & 0,04 & 0,81 \\
\hline BIS-PP & 0,37 & 0,03 \\
\hline Bll-GoMe & 0,27 & 0,14 \\
\hline AFAT & 0,05 & 0,75 \\
\hline AFAl & $-0,16$ & 0,36 \\
\hline
\end{tabular}




\subsection{Recidiva clínica}

Tabela 6- Trespasse vertical inicial, final e no mínimo, cinco anos pós-tratamento, demonstrando que, após a fase T3, oito pacientes $(25,8 \%)$, apresentaram uma recidiva "clinicamente não significante".

\begin{tabular}{|c|c|c|c|}
\hline Pacientes & BIS-PO t1 & BIS-PO t2 & BIS-PO t3 \\
\hline A.F.S. & $-1,4$ & 1,8 & 2,8 \\
\hline A.S. & $-1,5$ & 2,1 & 2 \\
\hline A.A. M. & -4 & 0,6 & 1 \\
\hline A. R. Jr. & $-2,7$ & $-0,1$ & 2 \\
\hline A.A. Jr. & $-2,1$ & 1,1 & $-0,5$ \\
\hline C. C. 0 . & $-7,7$ & 1,5 & $-1,7$ \\
\hline C. M.R. & -2 & 3,2 & 3,1 \\
\hline D. S. M. & $-3,5$ & 1,8 & $-0,1$ \\
\hline E.D.P.F. P. & $-2,1$ & $-0,1$ & 0,2 \\
\hline F.C. & $-8,4$ & $-0,5$ & $-2,6$ \\
\hline J. R. T. & $-1,4$ & 2,3 & 3,2 \\
\hline J. C.A.O. & $-3,6$ & 1,6 & 1,5 \\
\hline K.C. & -1 & $-0,1$ & 0,9 \\
\hline L. F. & $-2,2$ & 1,6 & 2,1 \\
\hline M. S. R. & $-6,3$ & 1,6 & $-0,1$ \\
\hline M. R.F. & $-1,9$ & 0,0 & 1 \\
\hline M. P. & $-2,2$ & 0,7 & 1,3 \\
\hline M. S. G. & $-2,5$ & 0,0 & 0,8 \\
\hline M. A. & -2 & 1,8 & 2,9 \\
\hline M. C. & $-1,5$ & 0,7 & 1,6 \\
\hline M. A. & $-3,1$ & 0,4 & $-1,6$ \\
\hline M. C. & $-3,6$ & 2,2 & 0,7 \\
\hline M. A. G. & $-1,4$ & 0,5 & 2,9 \\
\hline N. M. & $-2,3$ & 0,8 & 0,5 \\
\hline R. M. & $-4,2$ & 1,7 & 0,3 \\
\hline R. J.L.G. & $-1,5$ & 1 & $-0,4$ \\
\hline R. W. & $-2,3$ & 0,9 & 1,8 \\
\hline S. M. & $-1,6$ & 1,2 & $-0,3$ \\
\hline S. F. C. & $-1,8$ & 2,4 & 1,3 \\
\hline T. G. S. & $-2,3$ & $-0,7$ & 0,1 \\
\hline V. G. & $-0,8$ & 1,7 & 5,1 \\
\hline
\end{tabular}




\subsection{Erro Metodológico}

Os valores, que se encontram na tabela 7, demonstram a ausência de significância na comparação dos valores tomados previamente e durante a realização deste estudo, para todas as grandezas utilizadas. Desta forma, o erro sistemático foi considerado sem significância para a interpretação dos resultados obtidos, em relação a todas as grandezas cefalométricas.

Quanto ao erro casual, considerando que erros acima de 1 milímetro para as medidas lineares e de 1,5 graus para as angulares, seriam significantes, não verificou-se significância para nenhuma das grandezas utilizadas. Desta forma, na interpretação dos resultados obtidos nesta pesquisa, considerou-se que o erro casual não influenciou de modo significativo os resultados de todas as medidas cefalométricas, como demonstrado na tabela 7. 
Tabela 7 - Análise estatística para confirmar a confiabilidade do método cefalométrico. Apresentação das médias e desvios-padrão, para os dois tempos realizados, do teste "t" de Student e do erro casual (Dahlberg) para cada medida analisada.

\begin{tabular}{|c|c|c|c|c|c|}
\hline MEDIDAS & $\begin{array}{l}\text { Te } \\
\times \quad \mathrm{DP}\end{array}$ & $\begin{array}{l}\text { T3 } \\
\times \quad \mathrm{DP}\end{array}$ & $\begin{array}{c}\text { DAHLBERG } \\
\text { E }\end{array}$ & $\begin{array}{l}\text { Teste } \\
\text { " } \mathrm{t} \text { " }\end{array}$ & $\mathbf{P}$ \\
\hline SNA & $79,89 \pm 3,97$ & $79,38 \pm 3,63$ & 0,65 & 0,86 & $0,4 C$ \\
\hline SNB & $76,15 \pm 4,11$ & $76,07 \pm 3,79$ & 0,38 & 2,59 & 0,14 \\
\hline ANB & $3,73 \pm 2,36$ & $3,30 \pm 2,29$ & 0,69 & 0,49 & $0,6 z$ \\
\hline SN.GoGN & $37,53 \pm 4,45$ & $38,90 \pm 4,51$ & 0,52 & 0,12 & $0,9 C$ \\
\hline FMA & $28,43 \pm 4,84$ & $30,17 \pm 4,59$ & 0,93 & 0,77 & 0,44 \\
\hline SN.PP & $8,12 \pm 2,52$ & $8,10 \pm 3,45$ & 0,60 & 0,67 & $0,5 c$ \\
\hline Ar.GoGn & $126,17 \pm 6,27$ & $128,16 \pm 5,4 €$ & 0,84 & 1,35 & $0,1 \subseteq$ \\
\hline SN.PO & $16,21 \pm 4,35$ & $16,44 \pm 4,29$ & 0,84 & 0,44 & $0,6 \epsilon$ \\
\hline Ar-Go & $43,38 \pm 3,1 \varepsilon$ & $43,69 \pm 3,46$ & 0,98 & 1,21 & 0,24 \\
\hline S-Go & $72,31 \pm 5,77$ & $72,40 \pm 5,19$ & 0,88 & 0,64 & $0,5 \varepsilon$ \\
\hline 1S.PP & $112,51 \pm 7,8 ; 3$ & $111,38 \pm 7,4 €$ & 1,45 & 0,38 & 0,71 \\
\hline IMPA & $89,98 \pm 4,8 €$ & $88,00 \pm 5,42$ & 1,11 & 0,23 & 0,81 \\
\hline 1S-NA & $4,96 \pm 2,96$ & $5,21 \pm 2,62$ & 0,50 & 0,44 & 0,65 \\
\hline $1 \mathrm{I}-\mathrm{NB}$ & $6,40 \pm 1,46$ & $6,21 \pm 1,53$ & 0,43 & 0,88 & $0,3 \varepsilon$ \\
\hline 1S.NA & $24,96 \pm 6,54$ & $24,41 \pm 6,60$ & 1,46 & 0,41 & $0,6 \varepsilon$ \\
\hline 1I.NB & $25,77 \pm 3,9 C$ & $25,05 \pm 4,29$ & 1,02 & 1,16 & 0,25 \\
\hline 6S-PP & $26,32 \pm 2,5 €$ & $26,47 \pm 2,15$ & 0,62 & 0,10 & 0,91 \\
\hline 6I-GoGn & $32,13 \pm 2,1 \epsilon$ & $32,40 \pm 1,86$ & 0,94 & 0,51 & 0,61 \\
\hline BIS-PP & $29,80 \pm 3,04$ & $30,36 \pm 2,79$ & 0,58 & 0,22 & $0,8 \varepsilon$ \\
\hline Bll-GoGn & $40,36 \pm 2,55$ & $40,74 \pm 2,59$ & 0,48 & 0,60 & 0,55 \\
\hline AFAT & 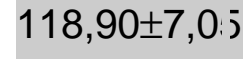 & $118,66 \pm 7,0 \varepsilon$ & 0,88 & 0,64 & $0,5 \varepsilon$ \\
\hline AFAl & $70,83 \pm 5,7$ & $72,12 \pm 5,44$ & 0,78 & 1,08 & $0,2 \varsigma$ \\
\hline BIS-Po & $0,99 \pm 1,33$ & $1,02 \pm 1,62$ & 0,77 & 0,28 & 0,77 \\
\hline
\end{tabular}




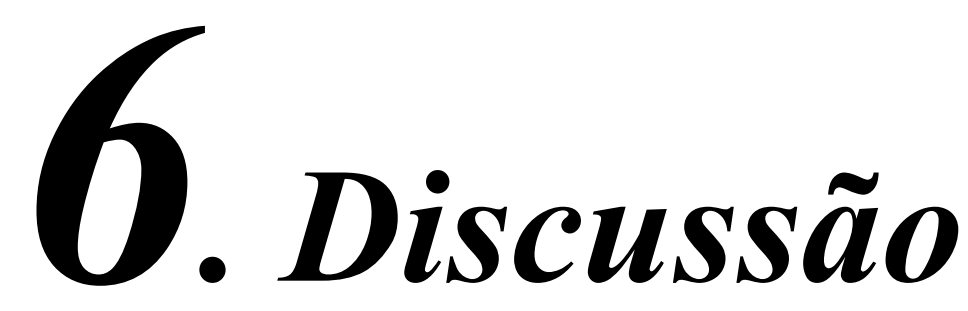




\section{6- DISCUSSÃO}

Com o objetivo de proporcionar o entendimento dos resultados obtidos neste trabalho, dividimos este capítulo em:

\subsection{Seleção da amostra;}

\subsection{Metodologia empregada;}

\subsection{Interpretação das características cefalométricas iniciais da amostra;}

\subsection{Interpretação das alterações obtidas durante as fases inicial e logo} após o término do tratamento;

6.5 Interpretação das alterações obtidas durante as fases final e em média, cinco anos pós-tratamento.

\subsection{Recidiva clínica}

\subsection{Considerações clínicas}

\subsection{Seleção da amostra}

A mordida aberta anterior é um dos temas mais citados na literatura, porém, quanto à sua estabilidade após o término de tratamento ortodôntico poucos autores têm relatado. Assim, selecionou-se esta amostra seguindo alguns requisitos, como: todos os 31 pacientes apresentavam-se em fase de dentadura permanente, sem multilações nos arcos dentários, o que promove uma maior homogeneidade da amostra, que apresentaram inicialmente uma mordida aberta anterior de no mínimo $1 \mathrm{~mm}$, considerando que a mordida aberta anterior é definida por VAN DER LINDEN ${ }^{150}$, SUBTELNY ${ }^{144}$, NGAN $^{102}$, MOYERS ${ }^{92}$, WATSON ${ }^{152}$, ALMEIDA $^{6}$ e MARTINS ${ }^{84}$, como a ausência de contato entre as bordas dos dentes anteriores superiores e inferiores, medindose no sentido vertical, a qual foi observada clinicamente nos modelos, embora nos resultados cefalométricos apresentou-se com, no mínimo, 0,8mm.

A amostra também apresentou o mínimo de cinco anos após o término de tratamento; no entanto, a literatura demonstra que a maioria dos trabalhos, que verificaram a estabilidade do tratamento da mordida aberta, avalia no 
máximo 1 a 2 anos após o término de tratamento, como demonstrado nos trabalhos realizados por GOTO ${ }^{56}, \mathrm{KIM}^{72}$ e KÜÇÜKKELES ${ }^{74}$. Desse modo, os trabalhos realizados por LOPEZ-GAVITO ${ }^{81}$ e PARRA $^{108}$ apresentam-se bastante interessantes, por relatarem as mudanças ocorridas nos tecidos ósseo e dentário dos pacientes, após um período mínimo de 9,6 e cinco anos do término do tratamento respectivamente.

A amostra também apresentou discrepância entre o volume dentário e o osso de suporte, com grande sobressaliência anterior e um perfil facial desfavorável, com lábio hipotônico e padrão de crescimento facial vertical. Devido a essas razões mencionadas, tornou-se necessária a realização do tratamento ortodôntico com extrações dentárias, em todos os casos, realizando-se extrações de primeiros pré-molares, segundos pré-molares ou primeiros molares, sem haver distinção da amostra por grupos de dentes extraídos. É importante relatar que a maioria das pesquisas sobre a estabilidade da mordida aberta após o tratamento ortodôntico fixo, apresenta amostras incluindo juntamente casos com e sem extrações, o que pode gerar resultados que não condizem com a realidade, uma vez que novos estudos ${ }^{108}$, ${ }^{25}$ têm sugerido que o tratamento com extrações pode proporcionar resultados mais estáveis, em relação ao tratamento sem extrações, de forma que $\mathrm{CHANG}^{25}$ foi o único que utilizou uma amostra apenas sem extrações, para estudar a estabilidade do tratamento da mordida aberta. Assim, esta pesquisa apresenta uma amostra de 31 casos, todos com extrações, apresentando resultados mais claros por não haver uma junção de casos sem extração.

Já que os trabalhos existentes na literatura não fazem distinção entre pacientes que apresentam má oclusão de Classe I ou Classe II no grupo experimental $\left.\right|^{37,42,43,63,69,72,74}$. Como também, não enumeram que essa característica possa influenciar na estabilidade final do tratamento ortodôntico. Esta amostra apresenta juntamente 30 casos com má oclusão de Classe II e um caso com má oclusão de Classe I.

Outro requisito constituiu-se na realização do tratamento com aparelho ortodôntico fixo, pela técnica de "edgewise" simplificada, a qual era a técnica utilizada nessa instituição para a correção das más oclusões em fase de dentadura permanente. Alguns autores, como ENACAR ${ }^{42}$; KÜÇÜKKELES ${ }^{74}$; 
$\mathrm{KIM}^{71,72}$; e $\mathrm{CHANG}^{26}$, realizaram algumas modificações na técnica "edgewise" original, conservando as características iniciais, demonstrando haver uma grande eficácia no tratamento da mordida aberta anterior, principalmente quando se utiliza conjuntamente aos elásticos verticais na região anterior.

Conforme apresentado detalhadamente no capítulo de Material e Métodos, o material consistiu de três telerradiografias em norma lateral para cada paciente estudado, as quais foram realizadas no início do tratamento (T1), imediatamente após o término do tratamento (T2) e, no mínimo, cinco anos após o término de tratamento (T3). Esta avaliação cefalométrica das alterações dentárias e esqueléticas nos períodos estudados, é amplamente utilizada na literatura como se observa nos trabalhos realizados por $\mathrm{CHANG}^{25}$, HUANG $^{63}, \mathrm{KIM}^{72}$, KÜÇÜKKELES ${ }^{74}$, LOPEZ-GAVITO ${ }^{81}$ e PARRA ${ }^{108}$.

\subsection{Metodologia empregada}

$\mathrm{Na}$ nossa metodologia, a análise de modelos, apesar de ter sido realizada, foi desprezada, uma vez que muitos fatores externos influenciaram na medição dos resultados, verificando-se a existência apenas de um trabalho na literatura que avaliou a mordida aberta por meio dos modelos de gesso, realizado por NEMETH ${ }^{101}$, porém o autor não explicou detalhadamente, em seu artigo, como executou a sua medição.

A avaliação das grandezas cefalométricas de forma computadorizada, permitiu a utilização de um maior número de dados em menor período de tempo, como também uma menor probabilidade de erros na obtenção dos valores das variáveis cefalométricas, assim como na fase de mensuração dos resultados. O programa utilizado foi o "Dentofacial Planner 7.02", que utilizado por diversos autores como, BISHARA ${ }^{16}$, BRAUN $^{21}$, CASSIDY $^{24}$, JANSON $^{67,68}$, PANCHERZ $^{107}$, POLLARD ${ }^{112}$ e STAGGERS ${ }^{139}$, em pesquisas renomadas, asseguram assim, sua confiabilidade.

Com o intuito de avaliar a recidiva após cinco anos de tratamento, mediu-se o trespasse vertical anterior de acordo com a metodologia empregada por ARPORNMAEKLONG ${ }^{11}$ e semelhante a de KÜÇÜKKELES ${ }^{74}$, que mediu da borda incisal do incisivo superior perpendicularmente ao plano 
oclusal funcional, apresentando-se negativo quando aquela se encontrou acima desse plano e positiva quando abaixo do mesmo. No entanto, nossa medição diferenciou-se dessa, apenas por se utilizar o plano oclusal de Downs, pois medindo-se o trespasse quando esse se encontra acima desse plano, o resultado pode ser interpretado como uma abertura real da mordida; entretanto, medindo-se pelo plano oclusal funcional, o trespasse pode apresentar-se negativo devido a esse plano, em muitos casos, encontrar-se abaixo da borda incisal dos incisivos inferiores, sem necessariamente existir clinicamente uma mordida aberta. NEMETH; ISACSON ${ }^{101}$, também utilizaram uma metodologia parecida, medindo-se o trespasse vertical pela distância entre os incisivos superiores e inferiores perpendicularmente ao plano oclusal funcional. Percebe-se que, ao utilizar o plano oclusal como parâmetro para avaliar o trespasse vertical procurou-se empregar um plano que sofresse as mesmas influências que a medida a ser analisada e, portanto, as mesmas variações, proporcionando resultados mais compatíveis com a realidade. Dessa forma, verificou-se uma diferença desta metodologia utilizada por HUANG ${ }^{63}$ e DENISON $^{37}$, os quais avaliaram o trespasse vertical pela distância entre as bordas dos incisivos superiores e inferiores, medida perpendicularmente à linha $\mathrm{N}-\mathrm{Me}$. Os mesmos relataram que essa linha como parâmetro, pode apresentar erros que possibilitam a distorção dos resultados finais da pesquisa. Isso pode ocorrer porque a linha N-Me apresenta-se formada pelos pontos cefalométricos $\mathrm{N}$ e Me, que são posicionados a grande distância, em escala cefalométrica da medida analisada BIS-Po (trespasse vertical). O que proporciona maiores chances de ocorrer erros durante a medição do trespasse vertical, pois dessa forma o valor dessa medida pode não representar a realidade. Esses pontos também podem sofrer grandes variações conforme o comprimento da base do crânio e rotação da mandíbula, e, sendo assim, maior é a probabilidade de se verificar erro na medição do trespasse vertical.

Outra metodologia que difere desta é a empregada por PARRA ${ }^{108}$, GILE $^{55}$ e LOPEZ-GAVITO ${ }^{81}$, que mediram a sobremordida como a distância linear, desde a borda incisal do incisivo inferior mais vestibularizado, acompanhando seu longo eixo até fazer contato com a estrutura de tecido duro oposta, pois, se os incisivos superiores mudarem no sentido ântero-posterior 
ou inclinarem pode causar um aumento ou diminuição nesta medida que nem sempre corresponde com a verdadeira sobremordida existente.

Quanto à subdivisão da amostra pelo padrão de crescimento facial não foi possível, observando-se que, na fase inicial (T1), as médias das medidas que expressam o padrão de crescimento facial demonstram-se aumentadas estatisticamente significante $(P<0,05)$. Ao se comparar com as médias das medidas, de um grupo controle de 15 pacientes, com más oclusões de Classe I e II aos $13 \operatorname{anos}^{85}$, que foi a média de idade da fase T1 dessa amostra, como apresentado na última tabela do capítulo-Apêndice, com 96,77\% dos pacientes apresentando padrão de crescimento vertical. Esse resultado confirma-se com os achados encontrados por BJÖRK ${ }^{18}$, ELLIS ${ }^{42}$; MC NAMARA ${ }^{86}$; NANDA ${ }^{82}$ e LOPEZ-GAVITO ${ }^{81}$, que os pacientes com mordida aberta apresentam uma grande tendência de crescimento facial vertical; Enquanto, nos opomos aos resultados apresentados por SWINEHART ${ }^{146}$ e HAPAK ${ }^{59}$, os quais concluíram que a mordida aberta pode ocorrer em diferentes tipos de padrão facial sem haver uma correlação estatisticamente significante.

Quanto ao teste estatístico utilizado para comparação do grupo controle, com a fase T1 da nossa amostra, realizou-se o teste"t", não pareado, por se tratar de grupos independentes, como utilizado por $\mathrm{CHANG}^{25}$ e LOPEZGAVITO ${ }^{81}$. Considerando-se então um único grupo de mordida aberta tratado, dividiu-se em três fases: inicial, final e cinco anos pós-tratamento, procedeu-se o teste estatístico "t" de Student pareado, em consonância com os trabalhos de $\mathrm{KIM}^{72}$ e CHANG ${ }^{25}$. E, por meio do teste de Pearson, de acordo com LOPEZGAVITO $^{81}$ correlacionou-se o trespasse vertical obtido cinco anos póstratamento com o trespasse vertical inicial (BIS-Po T1), final (BIS-Po T2-T1) e com todas as medidas avaliadas. 


\subsection{Interpretação das características cefalométricas iniciais da amostra}

Quando se comparou as médias das medidas cefalométricas de 31 pacientes desta amostra, durante a fase $\mathrm{T} 1$, com as médias das medidas, de um grupo controle de 15 pacientes, do Atlas de Crescimento Craniofacial ${ }^{85}$, apresentando más oclusões de Classe I e II aos 13 anos, observou-se algumas diferenças estatisticamente significante $(P<0,05)$. Os pacientes desta amostra apresentam planos mandibular e palatino divergentes, ramo mandibular diminuído e padrão de crescimento facial vertical, confirmando os achados de SUBTELNY;SAKUDA ${ }^{145}$, SASSOUNI I30; NEMETH; ISACSON ${ }^{101} ;$ FROST $^{52} \mathrm{e}$ LOPEZ-GAVITO ${ }^{81}$, porém nossos resultados não estão em sintonia com esses autores, no ponto em que afirmam que a altura dentoalveolar dos incisivos e molares superiores apresenta-se aumentada nos pacientes com mordida aberta em relação aos seus grupos controles, enquanto essas mesmas medidas (BIS-PP e 6S-PP), na presente pesquisa, não apresentaram alterações estatisticamente significantes. Quanto às alturas dentoalveolares dos incisivos e molares inferiores (BI-GoMe e 6I-GoMe), apresentaram-se estatisticamente diminuídas $(P<0,05)$, em relação ao grupo-controle, demonstrando que a interposição lingual impede 0 desenvolvimento dentoalveolar do arco inferior.

O padrão de crescimento acentuadamente vertical, foi observado pelas medidas SN.GoGn e Ar.GoMe, se encontram aumentadas estatisticamente em relação às medidas do $A_{t l a s}{ }^{85}$. Este padrão de crescimento aumentado está intimamente relacionado com a diminuição especulada da altura facial ânterosuperior, demonstrado pela acentuada diminuição estatisticamente significante do ângulo SN.PP, o que torna os planos e as linhas faciais divergentes em relação à base do crânio. Estes resultados estão de acordo com os trabalhos de BJÖRK ${ }^{18}$, CANGIALOSI $^{23}$, ELLIS ${ }^{42}$, ISAACSON ${ }^{64}$, LOPEZ-GAVITO ${ }^{81}$, SASSOUNI ${ }^{130}$, SUBTELNY ${ }^{142}$, WATSON ${ }^{152}$, SCHUDY, e RICHARDSON ${ }^{123}$; Enquanto, SUBTELNY; SAKUDA ${ }^{145}$ não encontraram diferenças significantes na altura facial ântero-superior, quando compararam um grupo controle de pacientes com mordida aberta, com um grupo de oclusão normal. Já $\mathrm{FROST}^{52}$ 
relatou um aumento na altura facial ântero-superior (AFAS), caracterizando um grupo de pacientes com mordida aberta, quando comparados com uma amostra controle de oclusão normal. Enquanto $\mathrm{NAHOUM}^{94}$ relatou uma diminuição da altura facial ântero-superior (AFAS), em um grupo de pacientes com mordida aberta. Em confirmação com $\mathrm{NAHOUM}^{94}$, a presente pesquisa demonstrou especulativamente uma diminuição da AFAS, já que a altura facial anterior total encontra-se estatisticamente diminuída $(P<0,05)$, a AFAI com aumento sem significância estatística e o ângulo SN.PP estatisticamente diminuído $(P<0,05)$, o que condiz com a inclinação superior da porção anterior do plano palatino quando relacionado à base do crânio, refletindo um desequilíbrio no desenvolvimento vertical anterior da maxila. Esses resultados encontram-se de acordo com os trabalhos realizados por SASSOUNI ${ }^{130}$; NAHOUM ${ }^{94,97}$; HAPAK ${ }^{59}$; SCHUDY ${ }^{133} ;$ ARVYSTAS $^{12}$, RICHARDISON $^{123}$ e MOYERS ${ }^{92}$.

O ramo ascendente mandibular (Ar-Go) e a altura facial posterior encontraram-se diminuídas estatisticamente nesta amostra, o que está intimamente relacionado com o aumento do ângulo goníaco (Ar.GoMe) e da altura facial ântero-inferior (AFAI), embora esta última, não tenha apresentado aumento estatisticamente significante, concordando com os resultados de SASSOUNI ${ }^{130}$, CANGIALOSI $^{123}$, ISCAN $^{65}$, SUBTELNY ${ }^{142}$, LOPEZ-GAVITO $^{81}$, NAHOUM ${ }^{94}$, ELLIS $^{42}$ e KIM ${ }^{72}$.

É importante relatar que nosso grupo controle foi obtido de um estudo longitudinal de pacientes com más oclusão de Classe I e II, realizado por MARTINS et $\mathrm{al}^{85}$., na Faculdade de Odontologia de Bauru - USP, enquanto a maioria desses trabalhos referidos anteriormente, utilizaram grupos-controle com oclusão normal. Entretanto, os últimos não pertencem às características faciais dos brasileiros, tornando-se mais adequada a utilização deste grupo controle. 


\subsection{Interpretação das alterações obtidas durante as fases inicial e logo após o término do tratamento}

Após a avaliação dos resultados demonstrados no capítulo anterior, verificamos que o tratamento ortodôntico fixo com extrações, para correção da mordida aberta anterior na dentadura permanente apresentou-se satisfatório. De forma que o fechamento da mordida ocorreu mais em conseqüência das alterações dentárias do que esqueléticas.

As grandezas angulares esqueléticas não demonstraram alterações significantes, como o ângulo do plano palatino com a base do crânio (SN.PP) apresentou, um aumento não estatisticamente significante (Figura 9), demonstrando que não houve uma restrição significante do crescimento posterior da maxila com a utilização do aparelho extrabucal (IHG). Este resultado coincide com o de LOPEZ-GAVITO ${ }^{81}$, que utilizou a mesma mecânica desta pesquisa, para correção de um grupo de 41 pacientes, com mordida aberta, e por KÜÇÜKKELES ${ }^{74}$, em que o plano palatino não apresentou inclinação no sentido horário em relação à base do crânio, demonstrando uma diminuição não estatisticamente significante deste ângulo. Este resultado não coincide com o apresentado por PARRA ${ }^{108}$, que observou um aumento estatisticamente significante neste ângulo, após utilizar a mesma mecânica que a nossa. $\mathrm{KIM}^{71}$, também apresentou resultados contrários, quando avaliou a inclinação do plano palatino em relação ao plano de Francfort, após o tratamento com a mecânica "MEAW", observando um aumento estatisticamente significante do ângulo SN.PP, que segundo o autor, pode ser atribuído ao fato de esse tipo de mecânica ter possibilitado uma suave intrusão dos molares superiores; Apesar desta, não apresentar-se estatisticamente significante. 


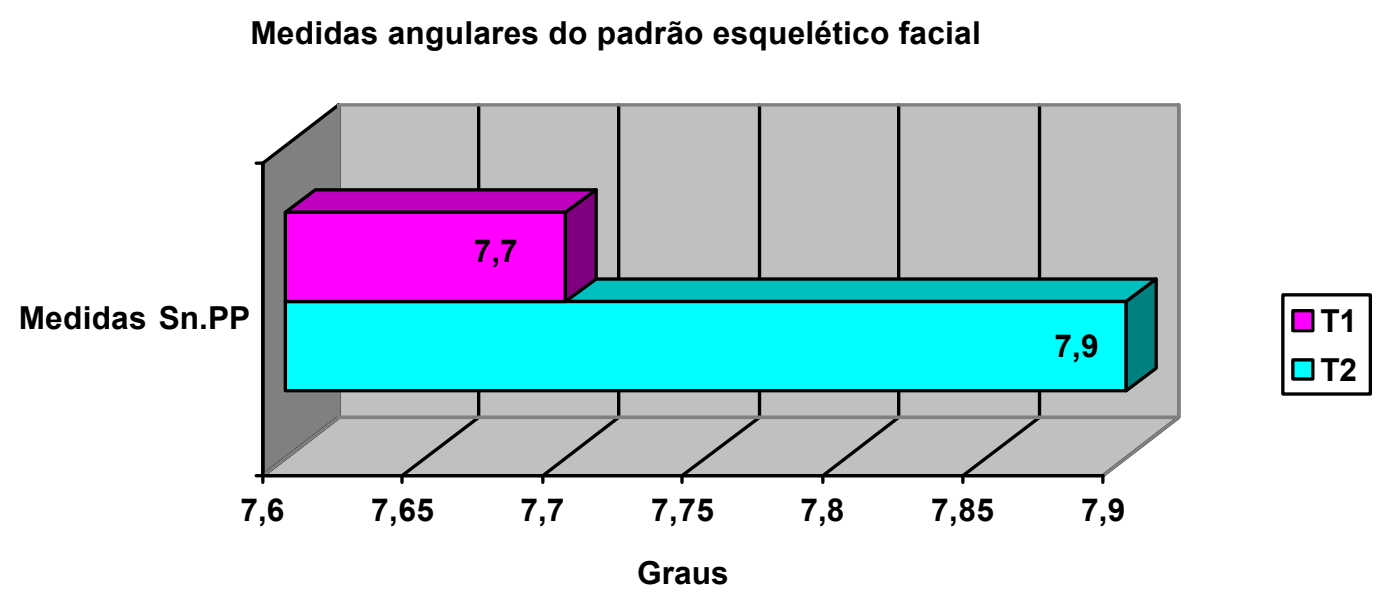

Figura 9 - Alteração do ângulo do plano palatino em relação à base do crânio, após o término de tratamento

Como também as grandezas SN.GoGn e FMA, que refletem o padrão de crescimento, não apresentaram alterações estatisticamente significantes nesta fase. Segundo BJÖRK ${ }^{18}$ e MARTINS ${ }^{85}$, o ângulo do plano mandibular formado tanto em relação ao plano de Francfort (FMA), como em relação à base do crânio (SN.GoGn), tende a diminuir com o crescimento; porém, segundo LOPEZ-GAVITO ${ }^{81}$ e RICKETTS ${ }^{125}$, na presença de hábitos, de crescimento anormal ou qualquer outra causa que impossibilite essa relação do plano mandibular com a linha SN ou com o plano de Francfort, esses ângulos podem ser alterados, produzindo uma rotação da mandíbula no sentido horário.

Desta forma, não se confirmou neste trabalho esses resultados, com estes ângulos apresentando um aumento não estatisticamente significante (Figura 10), o que demonstrou que a mecânica utilizada foi eficiente em controlar este aumento por meio dos elásticos intermaxilares utilizados na região anterior com aumento estatisticamente significante da altura facial posterior (S-Go) e do ramo mandibular (Ar-Go), compensando as forças extrusivas dos elásticos, sem os quais estes ângulos teriam aumentado 
significantemente, causando rotação mandibular posterior, com possível aumento da abertura da mordida.

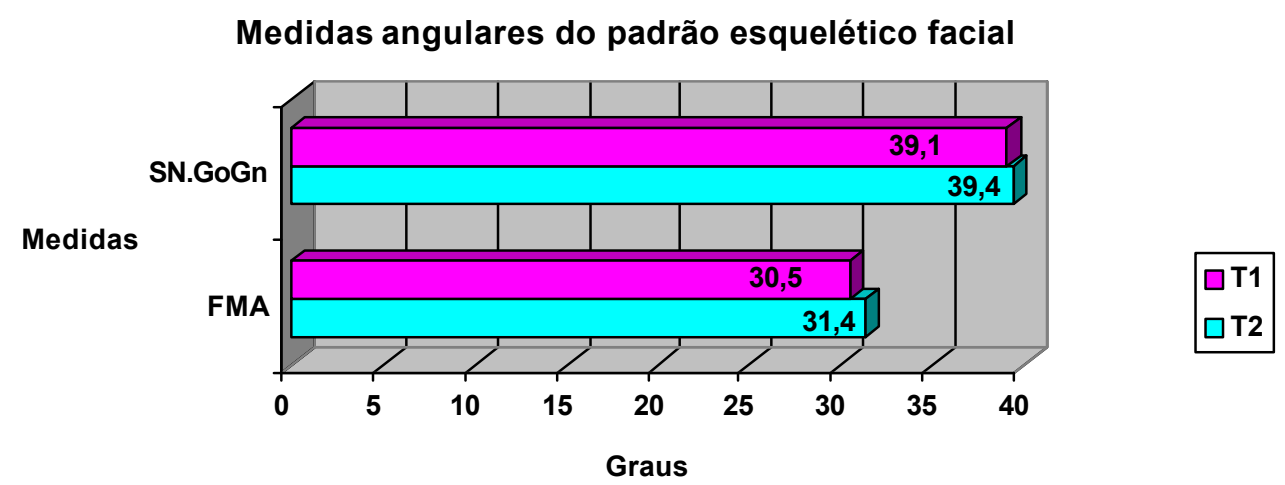

Figura 10 - Alterações do ângulo do plano mandibular em relação à base do crânio e do plano de Frankfort da fase T1 - T2

O ângulo goníaco (AR.GoMe), também comportou-se semelhantemente, sem alteração estatisticamente significante da fase T1 para T2 (Figura 11), provavelmente devido ao aumento estatisticamente significante do ramo mandibular (Ar-Go) e da altura facial posterior (S-Go) terem sido compensados pelo aumento estatisticamente significante da altura facial ântero-inferior, como foi relatado por ISAACSON ${ }^{64}$, o qual concluiu que, durante o desenvolvimento facial normal, o côndilo mandibular cresce verticalmente para tentar compensar a erupção dentária, de forma que uma sobrecompensação tende a diminuir o ângulo ANB e aprofundar a mordida, enquanto que o oposto pode causar a mordida aberta. Este resultado apresentou-se em sintonia com os resultados de $\mathrm{KIM}^{72}$ e LOPEZ-GAVITO $^{81}$, opondo-se aos resultados de PARRA ${ }^{108}$, que demonstrou uma diminuição estatisticamente significante deste ângulo. 


\section{Medidas angulares do padrão esquelético facial}

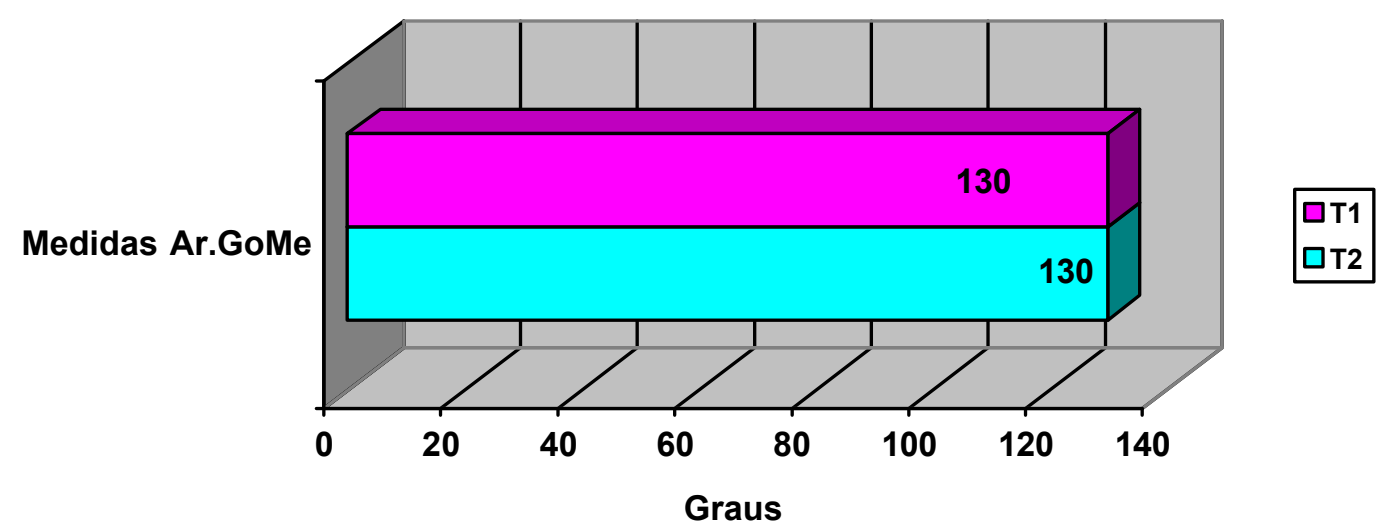

Figura 11 - Alteração do ângulo do plano mandibular em relação ao ramo mandibular, após o término de tratamento

Quanto as grandezas lineares esqueléticas, a altura facial ânteroinferior (AFAI) e a altura facial anterior total (AFAT), verificou-se um aumento estatisticamente significante $(P<0,05)$ após o término de tratamento (Figura 12). O que, provavelmente, esteja relacionado à mecânica empregada, com o uso de elásticos intermaxilares, causando extrusão dentária posterior e anterior, com crescimento ósseo compensatório na região posterior, no sentido vertical. Esses resultados apresentam-se em concordância com os trabalhos realizados por PARRA ${ }^{108}$, LOPEZ-GAVITO ${ }^{81}$, KIM $^{71}$ e KÜÇÜKKELES ${ }^{74}$.

\section{Medidas lineares do padrão esquelético facial}

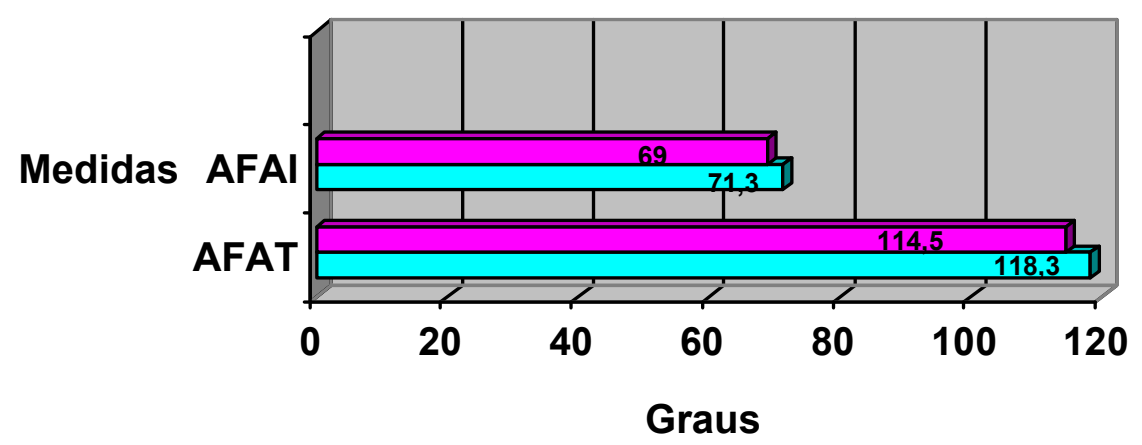

Figura 12 - Alterações das alturas faciais ântero-inferior e anterior total, após o término de tratamento 
Quanto às alterações dentárias pós-tratamento, os incisivos superiores e inferiores (1.PP, 1.NA, IMPA e 1.NB) demonstraram uma inclinação para lingual estatisticamente significante (Figura 13), o que é bastante compreensível, devido à mecânica com extrações necessitar de movimentos de retração dos dentes anteriores, juntamente com a utilização de elásticos intermaxilares verticais e de Classe II, utilizados durante a fase de finalização, concordando com os achados de LOPEZ-GAVITO ${ }^{81}$, PARRA ${ }^{108}$ e $\mathrm{KIM}^{72}$.

Medidas dentárias angulares

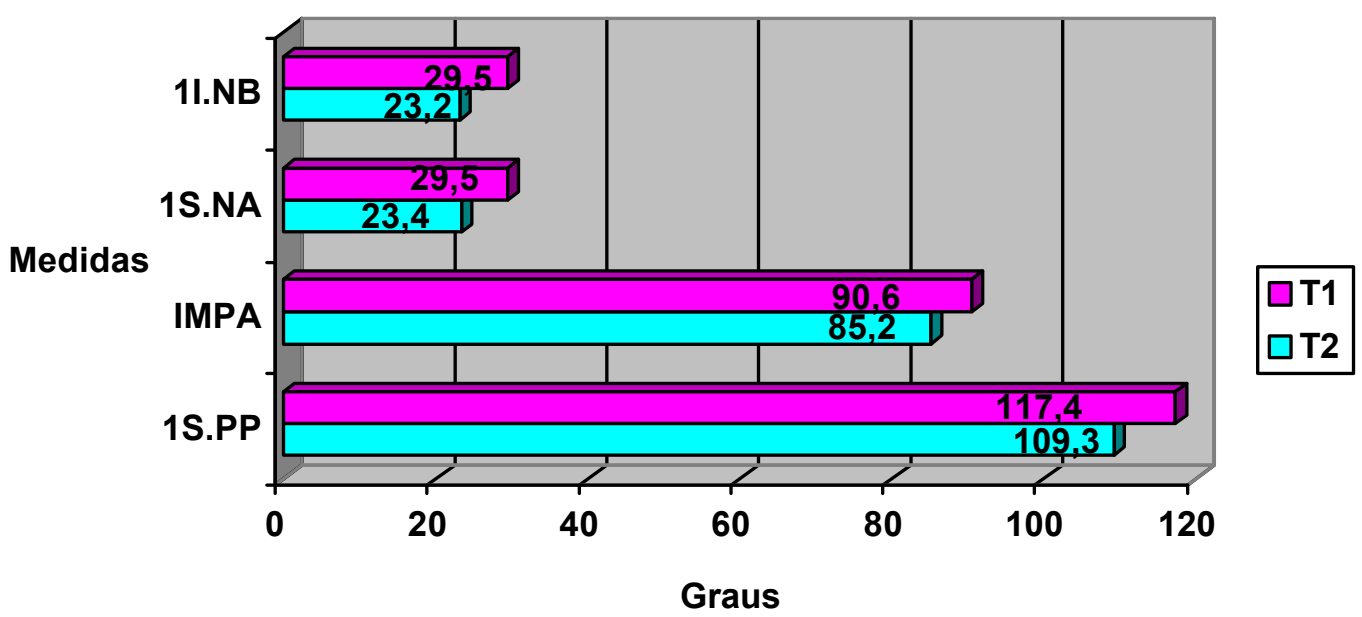

Figura 13 - Alteração das inclinações dos incisivos superiores e inferiores

Como também verificou-se as alterações nas as alturas dentoalveolares dos molares e incisivos superiores e inferiores (BIS-PP, BIIGoMe, 6S-PP e 6I-GoMe), aumentaram significantemente (Figura 14), devido à utilização de elásticos intermaxilares, para permitir o fechamento da mordida aberta, estando de acordo com os resultados apresentados por GOTO ${ }^{56}$, LOPEZ-GAVITO ${ }^{81}$, NEMETH; ISACSON ${ }^{108}$ e KÜÇÜKKELES ${ }^{74}$. O que confirma mais uma vez que a correção da mordida aberta com o tratamento ortodôntico fixo ocorre significantemente pela extrusão dos incisivos, mesmo quando é realizado com extrações de pré-molares ou molares como se apresentou na nossa amostra e os resultados apresentados por $\mathrm{KIM}^{72}$. O mesmo, utilizou a mecânica "MEAW" com fios apresentando várias alças e com curva reversa e 
acentuada, com o objetivo de intruir os molares, evitando assim grandes extrusões dos incisivos durante o fechamento. Apesar de ter obtido um pouco de intrusão, dos molares superiores ao final do tratamento, o mesmo não conseguiu evitar que houvesse extrusão dos incisivos superiores e inferiores e dos molares inferiores.

Medidas dentárias lineares

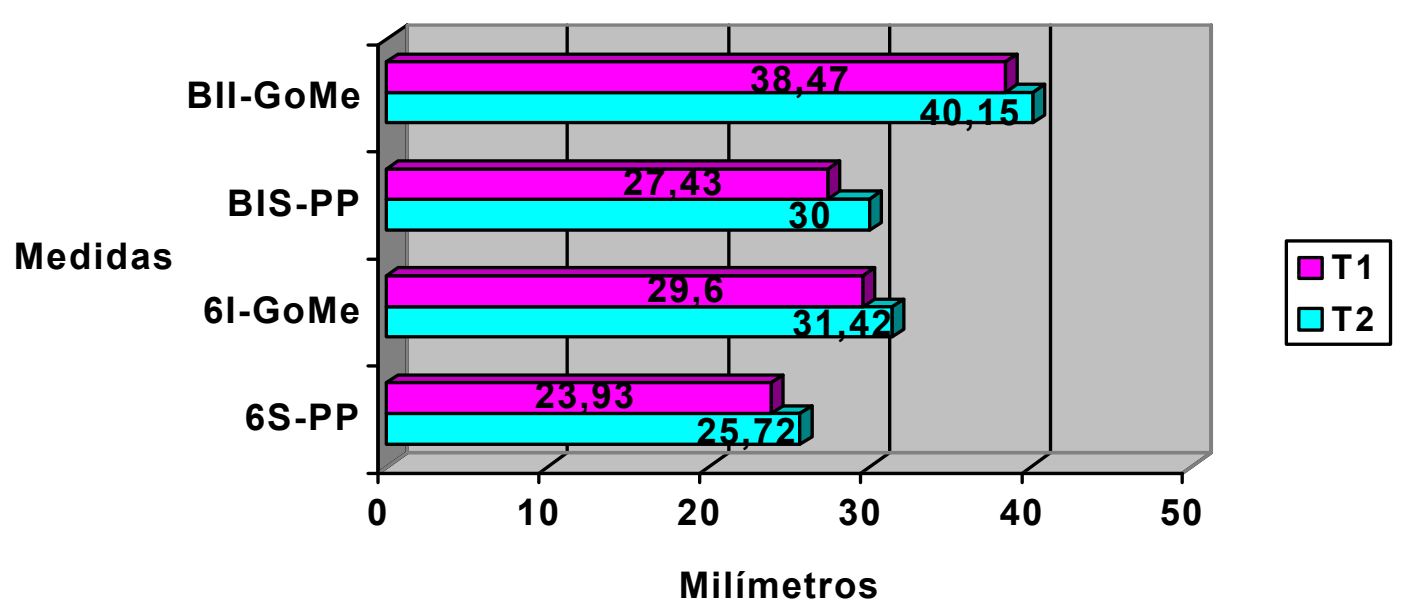

Figura 14- Alterações das alturas dentoalveolares dos incisivos e molares entre as fases $\mathrm{T} 1$ e T2

Estas alterações dentárias principalmente as extrusões dos incisivos, podem ser confirmadas pela alteração estatisticamente significante do ângulo do plano oclusal em relação à base do crânio. De forma que o plano oclusal rotacionou no sentido anti-horário, coincidindo com os resultados de $\mathrm{KIM}^{71}$; PARRA $^{108}$ e KÜÇÜKKELES ${ }^{74}$, que apresentou-se em conseqüência da extrusão dos incisivos inferiores possibilitando o fechamento da mordida aberta. (Figura-15) 


\section{Medidas angulares do padrão esquelético facial}

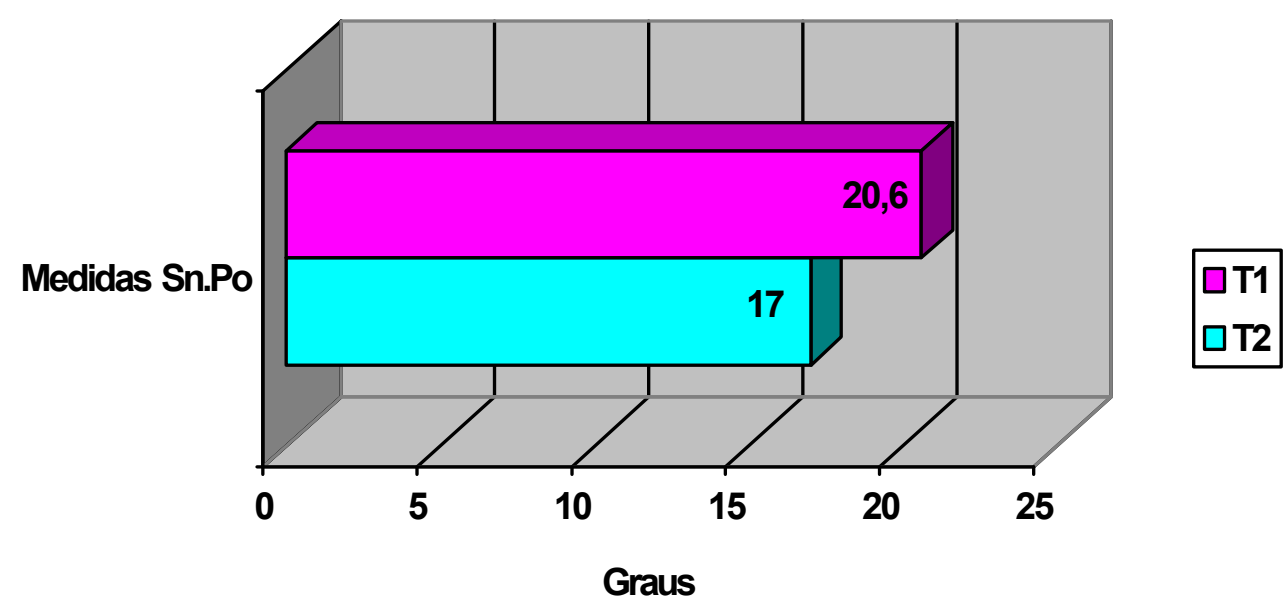

Figura 15 - Alteração da inclinação do plano oclusal em relação à base do crânio

A correção da mordida aberta anterior ao final do tratamento ortodôntico fixo apresentou um resultado satisfatório, obtendo-se um aumento estatisticamente significante do trespasse vertical (Figura 16), embora dos 31 pacientes desta amostra, cinco apresentaram-se com o trespasse negativo no máximo de 0,7mm como mostra a tabela 7, do Capítulo dos Resultados; porém, após cinco anos do término de tratamento, os mesmos se encontravam todos com trespasses verticais positivos, o que confirma os achados de BJÖRK ${ }^{18}$, ao estudar o desenvolvimento facial que, mesmo após os 20 anos de idade, pode ser observado algum crescimento condilar residual que possa interferir nas posições dentárias anteriores. Estes resultados satisfatórios com

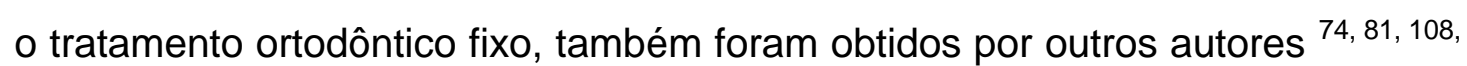
101, até mesmo em amostra de pacientes sem crescimento, como demonstrou $\mathrm{KIM}^{72}$, ao avaliar a mecânica "MEAW". 


\section{Trespasse Vertical}

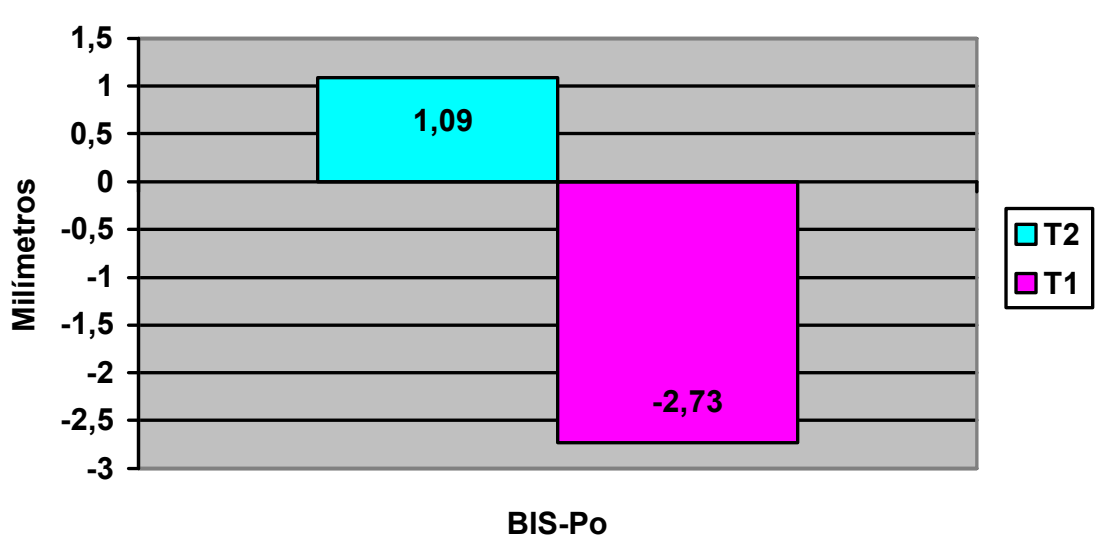

Figura 16 - Alteração do trespasse vertical após o término de tratamento

\subsection{Interpretação das alterações obtidas durante as fases final e 5 anos pós-tratamento.}

A estabilidade do tratamento ortodôntico é, provavelmente, o critério mais importante quando se decide por um método de tratamento para a correção da mordida aberta. O resultado desta pesquisa, após cinco anos de tratamento, demonstrou que houve uma estabilidade estatisticamente significante do trespasse vertical, representado pela grandeza cefalométrica (BIS-Po), (Figura 17), confirmando que este tipo de mecânica apresentou-se eficiente em manter a mordida aberta anterior corrigida. Este resultado coincidiu com os apresentados por KIM ${ }^{72}$, KÜÇÜKKELES ${ }^{74}$, LOPEZ-GAVITO ${ }^{81}$ e PARRA ${ }^{108}$. Como os resultados apresentados por KIM, utilizando-se a técnica "edgewise", com alças são semelhantes aos desta pesquisa, torna-se mais indicada a utilização da técnica "edgewise" simplificada do que a apresentada por este autor, devido a facilidade de aplicação pelos ortodontistas e conforto aos pacientes durante o tratamento ortodôntico, como também foi relatado por KÜÇÜKKELES ${ }^{74}$.

Quando se correlacionou o trespasse vertical obtido durante esta fase (BIS-Po T2-T3) com a fase inicial, observou-se que quanto maior a abertura da 
mordida inicialmente, maior será a recidiva cinco anos pós-tratamento (BIS-Po T2-T3) e ao se correlacionar com o trespasse obtido após o término de tratamento (BIS-Po T2), observou-se que quanto maior o trespasse vertical obtido após esta fase, menor será a recidiva após cinco anos de tratamento.

Porém, ao se correlacionar a recidiva com o restante das medidas apresentadas, observou-se que não houve correlação clínica expressiva, já que as correlações observadas das medidas SN.Po e BIS-PP demonstraram um valor de $r<0,8$ (Tabela 6), o que reflete uma correlação inexpressiva entre as alterações destes ângulos com a recidiva apresentada nesta amostra. Este resultado coincide com os apresentados por HUANG ${ }^{63}$ e DENISON ${ }^{38}$. Enquanto NEMETH; ISAACSON ${ }^{101}$ encontraram correlação após estudarem as alterações após o tratamento de pacientes com mordida aberta e sobremordida profunda, após um intervalo de 3,7 anos do término de tratamento. Essa correlação mostrou-se significante com o aumento da altura facial pósterosuperior, com uma significante rotação da mandíbula no sentido horário, o que proporcionou a abertura da mordida, com conseqüente aumento da altura dentoalveolar dos molares superiores em relação à base do crânio. Essa quantidade de recidiva também se mostrou variar com a idade e o potencial de crescimento apresentado pelo paciente ao final do tratamento ortodôntico.

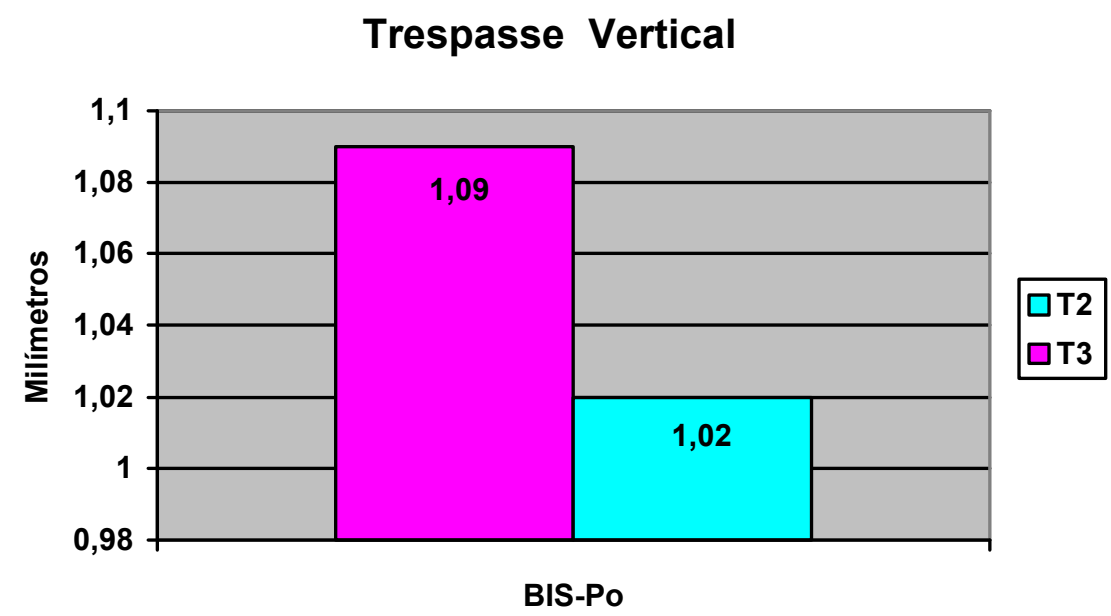

Figura 17 - Alteração do trespasse vertical cinco anos após o término de tratamento 
Ao se avaliar a estabilidade "clínicamente significante" demonstrada na tabela-7, do capítulo dos resultados, a mesma apresentou-se em $74,2 \%$ da amostra, semelhante ao resultado apresentado por LOPEZ-GAVITO ${ }^{81}$, ao avaliar a estabilidade da mordida aberta, após 10 anos de contenção dos casos conjuntos com e sem extração, em que demonstrou uma estabilidade de $65 \%$. PARRA $^{108}$ também, alcançou um resultado aproximado ao nosso, ao estudar a estabilidade da mordida aberta após cinco anos de contenção, dos casos tratados com e sem extração, observando-se uma estabilidade de $63 \%$ dos casos sem extração e de $75 \%$ dos casos com extração.

Após estudar 30 pacientes com mordida aberta tratados com grade palatina, tendo ainda alguns utilizado aparelho ortodôntico fixo, expansores e aparelhos extrabucais, HUANG $^{63}$, dividiu sua amostra em 23 pacientes que apresentavam crescimento e 7 que não apresentavam, demonstrando que houve uma recidiva clínica de $17,4 \%$ do grupo em crescimento e $0 \%$ do grupo sem crescimento, sem recidiva estatisticamente significante. Apesar dos resultados apresentados por $\mathrm{HUANG}^{63}$ demonstrarem-se satisfatórios, tornase, em parte, desfavorável afirmar tal conclusão, já que o grupo de pacientes sem crescimento mostrou-se muito pequeno para ser comparado com o que apresentou crescimento. Pelo fato de alguns pacientes terem utilizado aparelho ortodôntico fixo como complemento do tratamento com a grade palatina, então suas conclusões, de que $100 \%$ dos pacientes apresentaram sobremordida positiva em decorrência da utilização da grade, por ter mudado a postura lingual, torna-se um pouco duvidosa, assim como seu tempo mínimo de avaliação de um ano demonstrou-se muito curto para avaliar a estabilidade. Por outro lado, concordamos que o tratamento na dentadura mista seja mais eficiente do que na dentadura permanente, por apresentar uma porcentagem de recidiva clínica de apenas $17,4 \%$ nos pacientes em crescimento, em relação ao nosso de $25,8 \%$.

JUSTUS $^{69}$ também confirmou que o tratamento nesta fase é mais satisfatório, após apresentar um estudo clínico e cefalométrico de oito pacientes na dentadura mista, utilizando a grade palatina fixa com esporões; desses oito pacientes, cinco utilizaram apenas a grade, sendo avaliados, em 
média, três anos após o término de tratamento, observando $100 \%$ de estabilidade clínica dos casos. Embora, SUBTELNY e SAKUDA ${ }^{145}$ realizaram um estudo em 8 pacientes com idade acima de 12 anos, apresentando mordida aberta, tratando-as com grades palatinas fixas por 6 meses, sem obter bons resultados. Como também EPKER; $\mathrm{FISH}^{43}$, confirmaram que as grades palatinas são ineficazes para corrigir a mordida aberta, com exceção dos casos que apresentam crescimento e má oclusão de Classe I, com padrão facial equilibrado.

Quanto à estabilidade após o tratamento cirúrgico, $\mathrm{FROST}^{52}$, após comparar 19 pacientes, que não foram tratados ortodonticamente, apresentando má relação molar de Classe I, com um grupo de 13 pacientes adolescentes com mordida aberta, que se submeteram ao tratamento ortodôntico combinado ao cirúrgico, em que realizou reposicionamento da porção posterior da maxila para cima, observou que houve uma estabilidade estatisticamente significante da correção após 19 meses do término de tratamento. Embora esse autor como também ARPORNMAEKLONG ${ }^{11}$ encontraram $100 \%$ de estabilidade clínica, com este tipo de tratamento ortodôntico-cirúrgico, nos opomos em comparar esses resultados com os nossos, por apresentar um período muito curto para estudar a estabilidade após o término de tratamento.

Contrariando os resultados de FROST ${ }^{52}$, DENISON ${ }^{38}$ avaliou, após 1 ano do tratamento terminado, a estabilidade da cirurgia maxilar Le Fort I, em 28 pacientes com mordida aberta, observando uma recidiva estatisticamente significante de $42,9 \%$. Esta foi decorrente de um aumento significante da erupção dos molares superiores sem uma compensação de erupção dos incisivos superiores, diminuindo significantemente o trespasse vertical. Esse autor concluiu também que a musculatura peribucal deve ser avaliada durante o tratamento ortodôntico-cirúrgico, pois se a interposição da língua e a hipotonicidade da musculatura labial podem causar uma mordida aberta, na fase pré-tratamento, é aceitável que a recidiva da mordida aberta após o tratamento pode ser devido a essa mesma etiologia. A partir desse resultado, podemos sugerir que o tratamento ortodôntico fixo deva ser indicado como 
tentativa se evitar o cirúrgico, já que, além de causar muito trauma e apresentar riscos, não pode-se assegurar total estabilidade ao paciente.

REIKIK $^{119}$, realizou um estudo após 1 ano, em 16 pacientes com mordida aberta e retrognatismo mandibular, que se submeteram à osteotomia para avanço mandibular, realizando rotação anti-horária da mandíbula, utilizando a fixação interna rígida, em que se obteve total estabilidade em todos os contatos oclusais. Porém, esse autor, assim como ARPORNMAEKLONG ${ }^{11}$, apresentou um tempo pós-tratamento muito curto para avaliar a estabilidade de sua amostra, devido ao fato de que após a cirurgia ortognática, muitos pacientes ainda permanecerem, em média, por 6 meses com o aparelho ortodôntico, devendo-se avaliar a partir da remoção do aparelho ortodôntico e não do término da cirurgia.

Quanto ao desenvolvimento dentoesquelético verificou-se nesta pesquisa alterações estatisticamente significantes em algumas grandezas angulares e lineares.

Após avaliar o ângulo do plano mandibular em relação à base do crânio (SN.GoGn) durante essa fase (FIGURA 12), observou-se uma diminuição estatisticamente não significante, podendo-se inferir que houve uma pequena tendência do plano mandibular girar no sentido anti-horário, concordando com os resultados obtidos por GILE ${ }^{55}$, LOPEZ-GAVITO ${ }^{81} \mathrm{e}$ PARRA $^{108}$. Essa tendência se mostrou ainda mais expressiva ao se avaliar o plano mandibular em relação ao plano de Francfort (FMA), apresentando uma diminuição estatisticamente significante (Figura 18).

Enquanto $\mathrm{KIM}^{72}$, ao utilizar a mecânica "edgewise" com alças, observou um aumento desse ângulo estatisticamente não significante, ao avaliar tanto o grupo em crescimento como o sem crescimento, após dois anos do término de tratamento, demonstrando também que houve uma extrusão dos molares superiores estatisticamente não significante, o que talvez tenha levado ao aumento desse ângulo, sendo contrário à tendência normal de crescimento, como demonstrado por MARTINS ${ }^{85}$, que, em idade média, dos 15 aos 18 anos, ocorre uma diminuição deste ângulo proporcionado pelo crescimento do ramo mandibular, rotacionando a mandíbula no sentido anti-horário, o que confirma 
os nossos resultados. Como também, SCHUDY ${ }^{133}$, após avaliar as alterações faciais, com no mínimo cinco anos pós-contenção, verificou que houve um aumento da altura do ramo mandibular, ocorrido pela aposição óssea nas cabeças dos côndilos, deslocando a mandíbula em uma direção no sentido anti-horário, tendo como resultado uma diminuição deste ângulo.

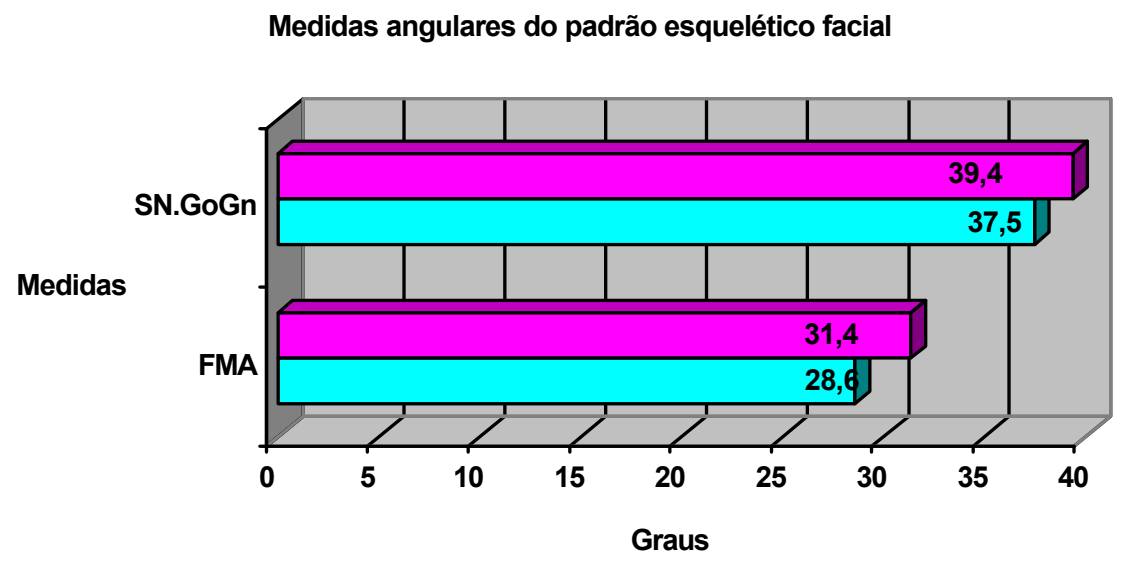

Figura 18- Alterações do ângulo do plano mandibular em relação à base do crânio e do plano de Francfort durante a fase T2-T3

Quanto à posição da maxila e da mandíbula em relação à base do crânio, (SNA e SNB), não houve alteração estatisticamente significante, assim como do ângulo ANB, durante esta fase (Figura 19), apresentando em sintonia com os resultados de KÜÇÜKKELES ${ }^{74}$, que avaliou 17 pacientes, 1 ano após o término de tratamento com idade média de 21 anos. Por meio da correção cirúrgica maxilar, FROST ${ }^{52}$ observou uma projeção do pogônio devido à autorrotação da mandíbula no sentido anti-horário, demonstrando um aumento estatisticamente significante do ângulo SNB, o que não ocorre com o tratamento ortodôntico fixo, apesar de esse ter apresentado um aumento não significante, e do plano mandibular também ter girado no sentido anti-horário, como demonstrado nos resultados desta amostra. 


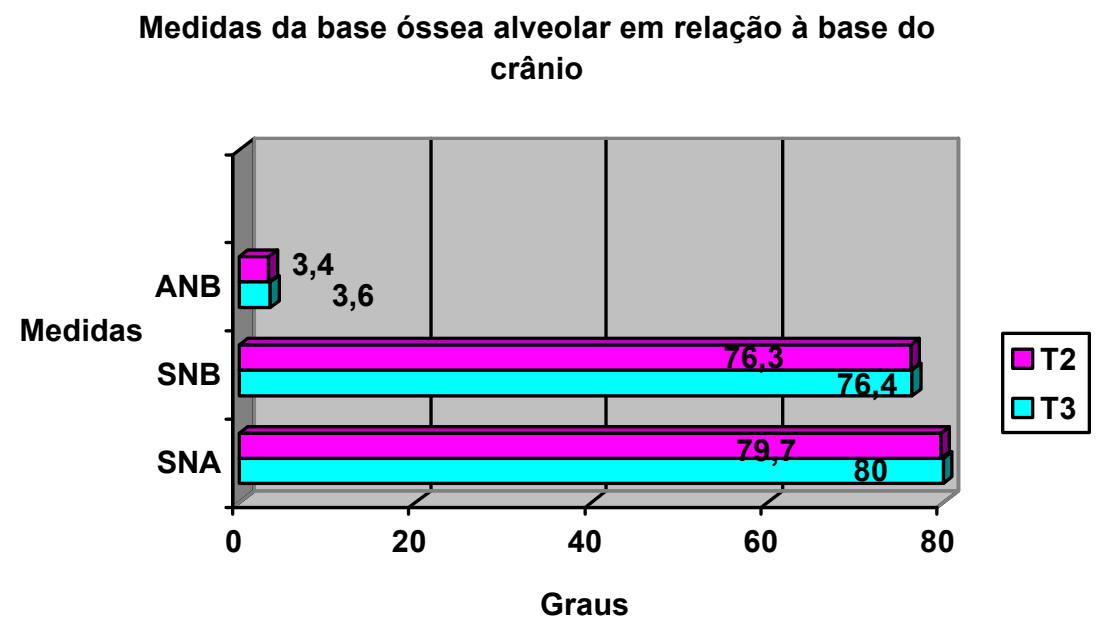

Figura 19 - Alteração das medidas angulares SNA, SNB e ANB durante a fase T2-T3

O ângulo do plano palatino em relação à base do crânio, (SN.PP) demonstrou um aumento estatisticamente não significante (Figura 20), o que deve ter contribuído para manutenção da estabilidade desta amostra, concordando com os resultados de KÜÇÜKKELES ${ }^{74}$ e LOPEZ-GAVITO ${ }^{81}$, os quais também não observaram alterações estatisticamente significantes nesta grandeza cefalométrica.

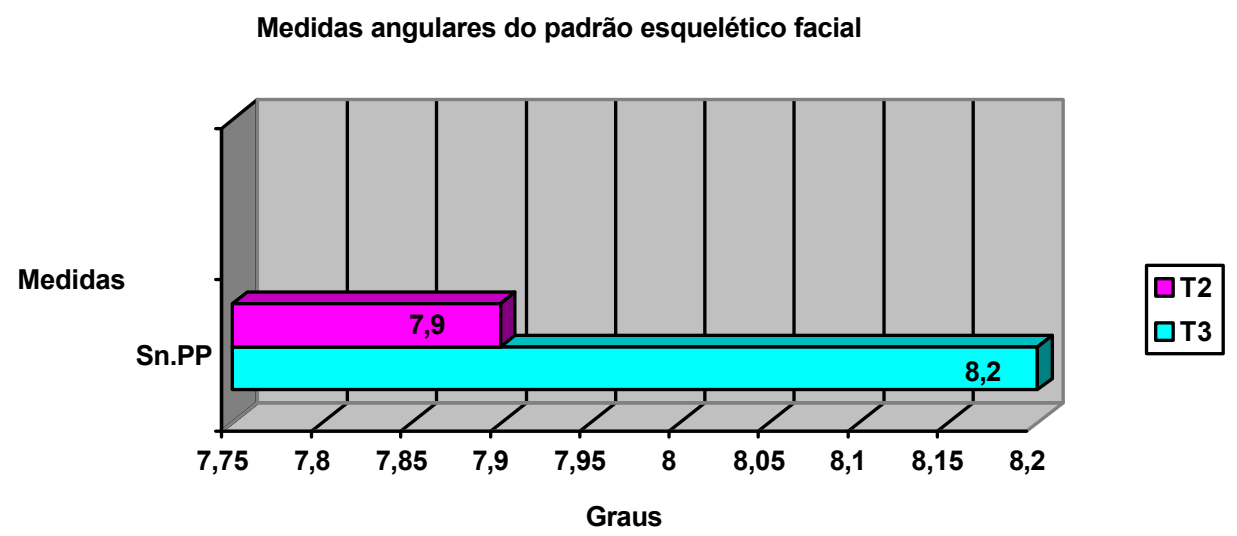

Figura 20- Alteração do ângulo do plano palatino em relação à base do crânio, durante a fase T2-T3 
Quanto ao ângulo do plano oclusal em relação à base do crânio (SNPo), observou-se uma diminuição estatisticamente não significante (Figura 21), refletindo a estabilidade do plano oclusal, devido, provavelmente, à extrusão dos molares e incisivos inferiores ocorrida paralelamente nesta fase, mantendo o trespasse vertical anterior obtido após o tratamento, o que coincidiu com os achados de PARRA ${ }^{108}$ e LOPEZ-GAVITO ${ }^{81}$. E, segundo SCHUDY ${ }^{133}$, o plano oclusal manteve-se estável nesta fase, devido ao final do tratamento ter se apresentado mais harmonioso com a estrutura esquelética e muscular facial, do que ao início do tratamento, quando a má oclusão encontrava-se instalada. Este resultado demonstra a eficiência da mecânica "edgewise", utilizada nesta amostra, pois MARTINS ${ }^{85}$ demonstrou que dos 15 aos 18 anos, este ângulo tende a aumentar, e caso esses pacientes não tivessem se submetido a tal tratamento, a tendência da mordida seria abrir ainda mais. Apresentando assim mais justificativas para tratar os pacientes com mordida aberta antes do término de crescimento.

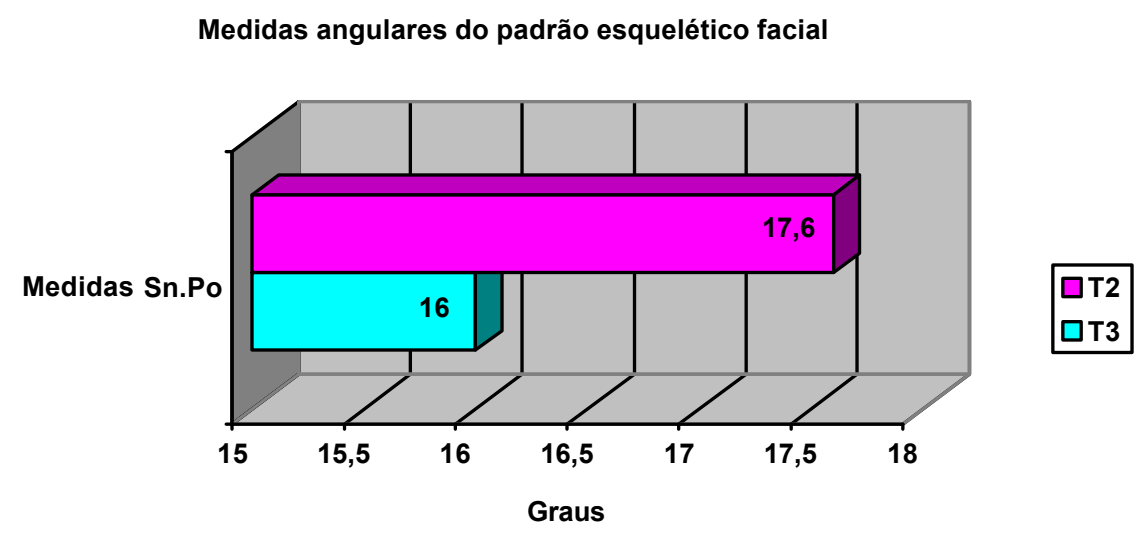

Figura 21 - Alteração da inclinação do plano oclusal em relação à base do crânio durante a fase T2-T3

As grandezas lineares esqueléticas representadas pelas alturas facial posterior (S-Go) e do ramo mandibular (AR-Go) apresentaram um aumento estatisticamente significante (Figura 22), o que condiz com a tendência de crescimento normal dessa região avaliada por MARTNS et al..$^{85}$, em uma idade dos 15 aos 18 anos, o que provavelmente propiciou a diminuição 
estatisticamente significante do ângulo do plano mandibular em relação ao ramo mandibular (Figura 23), indicando que a mecânica foi eficiente em direcionar o crescimento mandibular, evitando a recidiva. já, $\mathrm{KIM}^{72}$ demonstrou resultados não compatíveis com os nossos, em que o ângulo Ar.GoMe e a altura do ramo mandibular apresentaram aumentos estatisticamente significantes, o que pode ter sido em decorrência da sua análise estatística apresentar-se diferente da nossa.

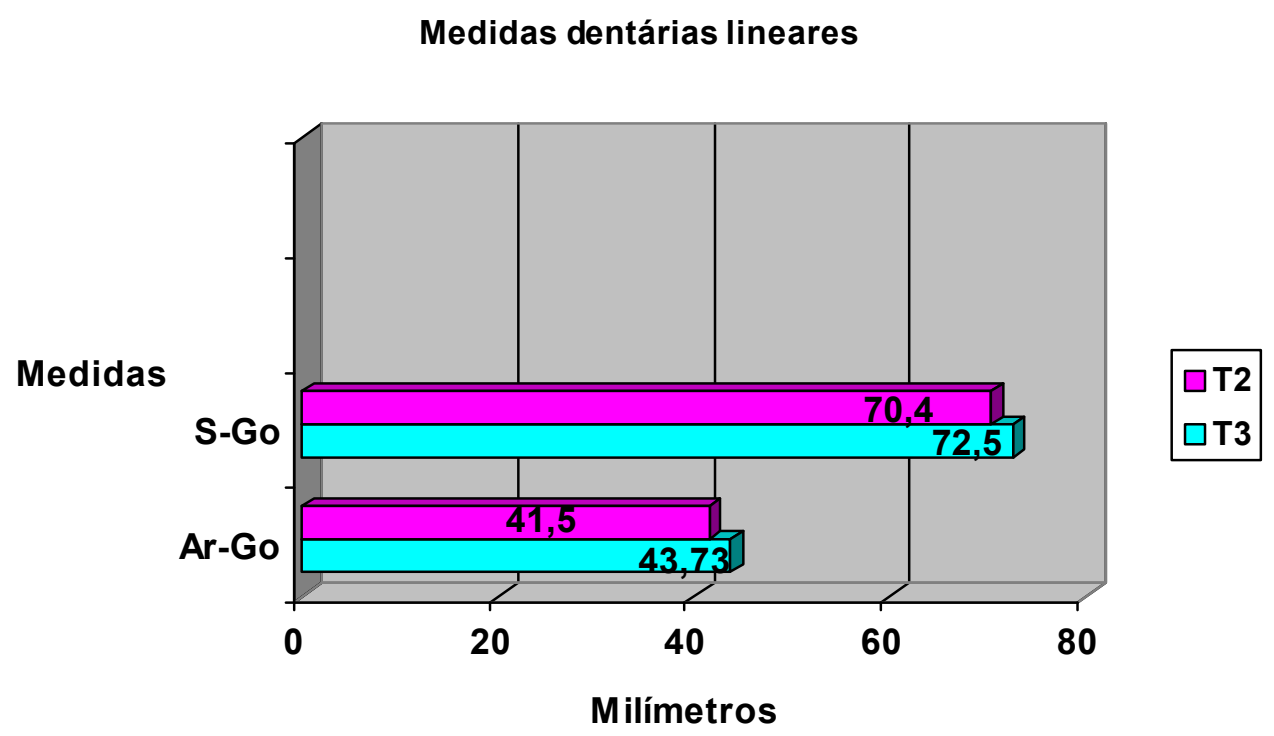

Figura 22 - Alteração das medidas lineares S-Go e Ar-Go durante a fase T2-T3 


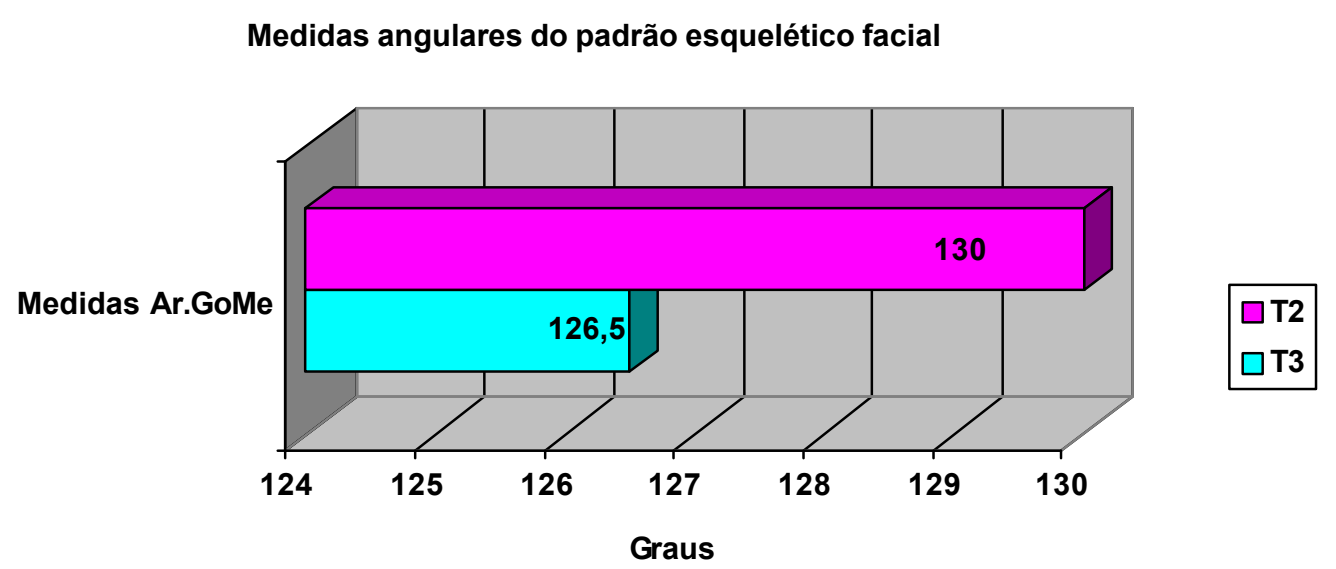

Figura 23 - Alteração do ângulo do plano mandibular em relação ao ramo mandibular duarante a fase T2-T3)

A altura facial anterior total apresentou um aumento estatisticamente significante (Figura 24), embora a altura facial ântero-inferior tenha demonstrado uma diminuição não significante (Figura 24), podendo este aumento da AFAT, ser atribuído à inclinação da porção anterior do plano palatino para baixo, devido ao crescimento dentoalveolar superior. Embora esse aumento não tenha sido estatisticamente significante, manteve 0 trespasse vertical estável estatisticamente significante, durante esta fase. FROST $^{52}$ demonstrou que a AFAl também apresentou uma diminuição não estatisticamente significante, o qual justificou que devido a esses pacientes apresentarem um crescimento no sentido vertical, torna-se difícil, mesmo após a autorrotação da mandíbula após a osteotomia Le Fort I, uma diminuição significante da AFAl. Assim, torna-se claro que esse tipo de tratamento cirúrgico da mordida aberta não deve ser indicado quando o objetivo principal for a diminuição da AFAl.

O nosso resultado apresenta-se de acordo com o de $\mathrm{KIM}^{72}$, em que a AFAl apresentou uma diminuição não significante, porém o mesmo apresentou que a AFAT permaneceu praticamente a mesma, sem alteração significante estatisticamente; já KÜÇÜKKELES ${ }^{74}$, apresentou um aumento estatisticamente significante da AFAT, enquanto a altura facial ântero-inferior apresentou uma 
diminuição não estatisticamente significante, concordando com os resultados desta pesquisa.

Devido a essa grande variação de resultados entre os autores, observa-se que tanto a AFAT como a AFAI, podem variar, diminuindo ou aumentando, sem haver necessariamente uma alteração dentoalveolar que venha comprometer a estabilidade do trespasse vertical anterior, demonstrando que a mordida aberta manteve-se estável em decorrência das extrusões dentárias, além da compensação óssea desencadeada pelo crescimento residual que apresentaram os pacientes após o tratamento terminado, concordando com os resultados de GOTO $^{56}$, LOPEZ-GAVITO ${ }^{81}$ e NEMETH; ISACSON $^{101}$.

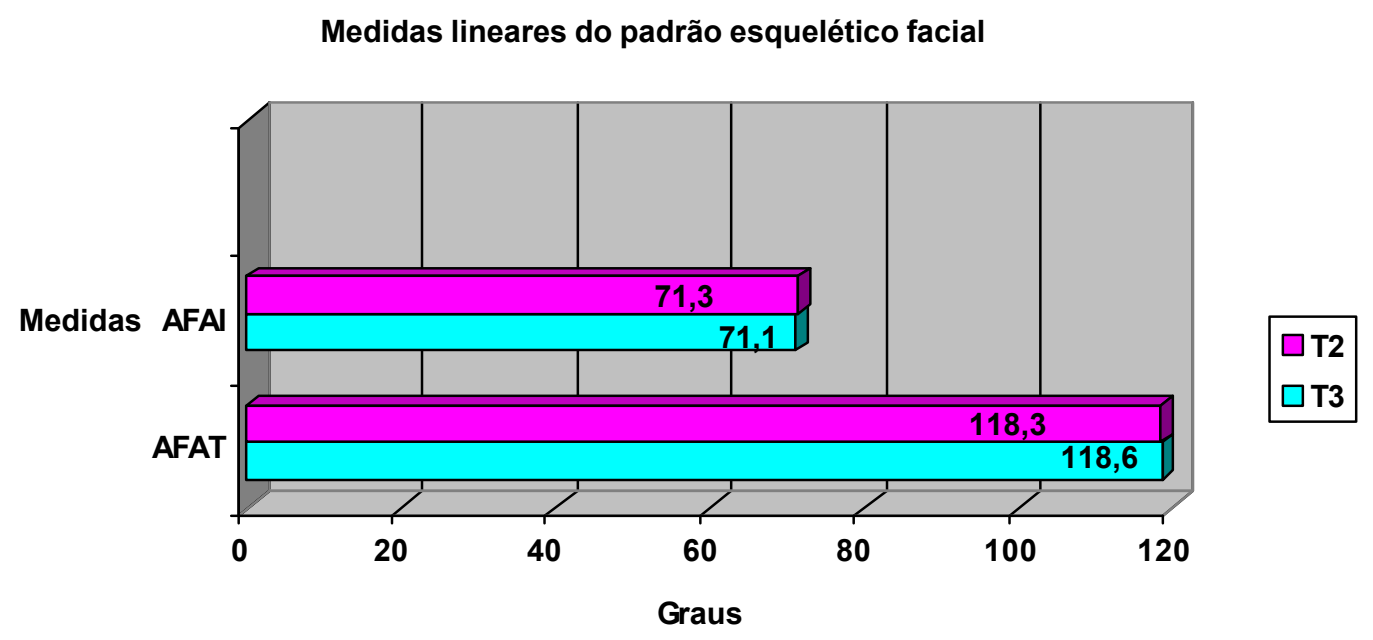

Figura 24 - Alterações das alturas faciais ântero-inferior e anterior total, durante a fase T2-T3

Quanto às alterações dentoalveolares, verificou-se nesta pesquisa que os incisivos inferiores apresentaram-se acentuadamente inclinados para vestibular em relação tanto ao plano mandibular quanto à base óssea apical (1.NB), como também apresentaram-se acentuadamente protruídos (BII-NB) em relação à base óssea apical e extruídos em relação ao plano mandibular (BII-GoMe), encontrando-se todas essas alterações significantes estatisticamente (Figura 25 e 26), apresentando a tendência de esses dentes 
retornarem às suas posições iniciais. O que provavelmente ocorreu por não se apresentar qualquer forma de contenção pôr vestibular, como no arco superior após a instalação da placa de Hawley. De forma que os incisivos superiores não apresentaram nenhuma alteração estatisticamente significante nesta fase. Porém, os resultados dessas medidas angulares (1.NB e IMPA) não condizem com os resultados apresentados por KÜÇÜKKELES ${ }^{74}$, LOPEZ-GAVITO $^{81}$ e PARRA $^{108}$, os quais chegaram a uma diminuição desses ângulos, provavelmente devido às suas amostras apresentarem casos juntamente com e sem extrações.

Verificou-se ainda que o aumento da altura dentoalveolar dos incisivos inferiores compensou o aumento da altura dentoalveolar dos primeiros molares superiores e inferiores, mantendo o trespasse vertical estável durante esta fase (Figura-25).

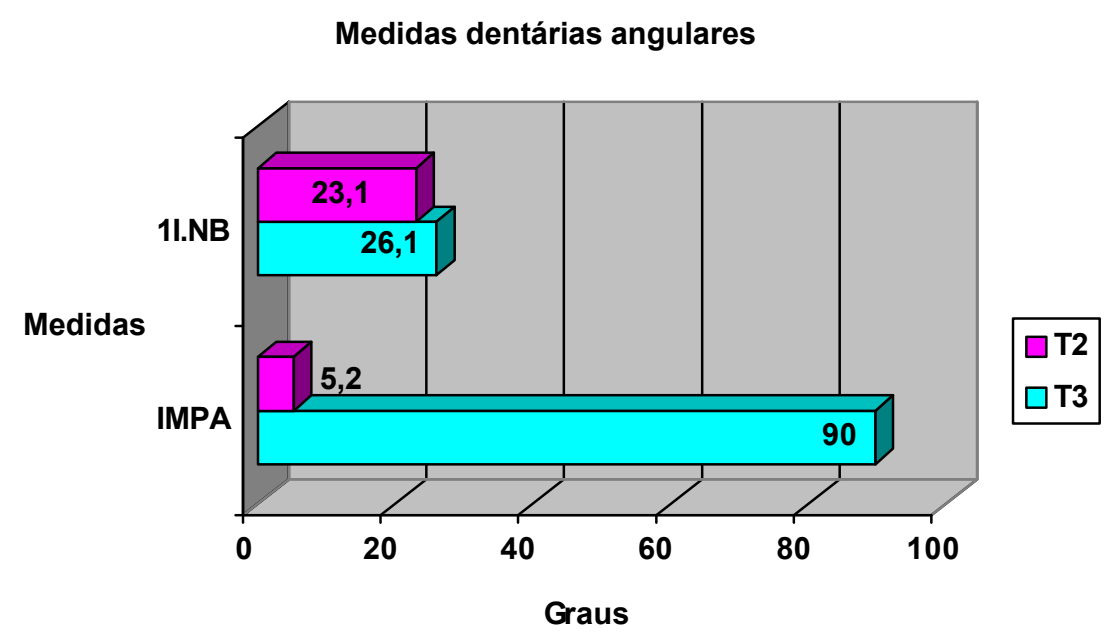

Figura 25 - Alterações das medidas angulares IMPA e 1.NB, durantes a fase (T2-T3) 
Medidas dentárias lineares

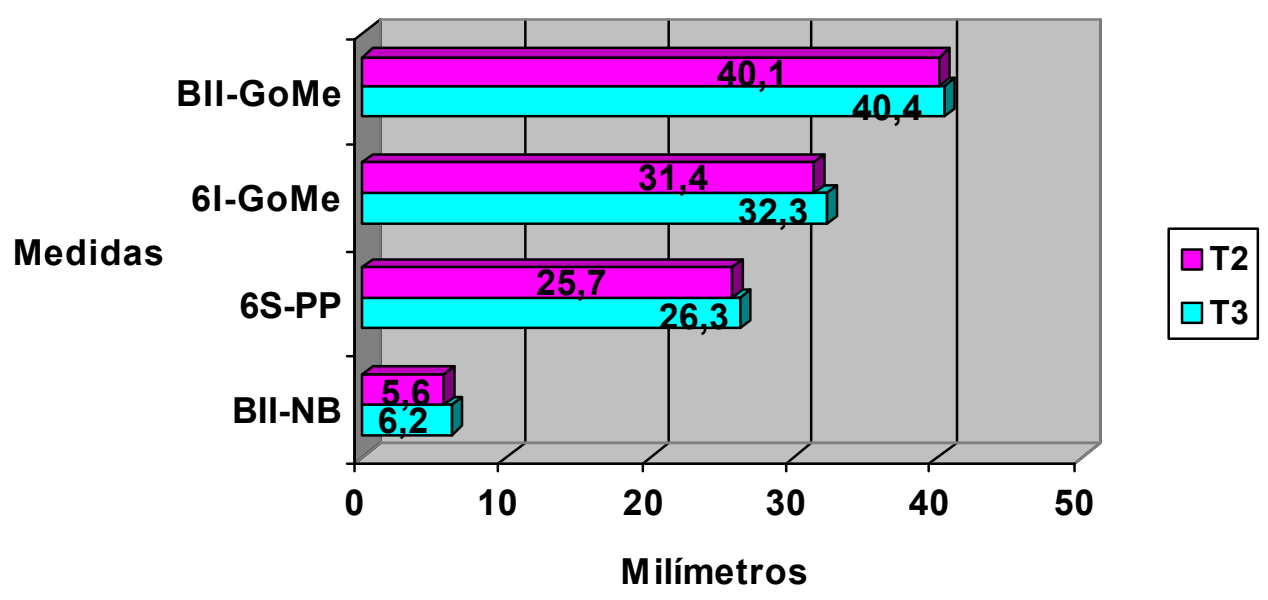

Figura 26 - Alterações das medidas lineares BII-GoMe, 6I-GoMe, 6S-PP e BII-NB, durante a fase T2-T3. 


\subsection{Recidiva clínica}

Como forma de se tornar mais claro os resultados deste trabalho para o ortodontista decidiu-se avaliar a recidiva "clinicamente significante" da mordida aberta anterior. Essa forma de avaliação, proposta por alguns autores $^{37,81,108}$ foi utilizada nesse estudo por se constituir em um meio de avaliação do real objetivo do tratamento da mordida aberta que é a obtenção e manutenção, a longo prazo, do trespasse vertical positivo.

A recidiva observada nesse estudo reflete apenas se as alterações que ocorreram no trespasse vertical entre o final do tratamento e cinco anos após, são estatisticamente significantes, mas não demonstram se os pacientes voltaram a apresentar mordida aberta, após esse período. Também não demonstram a porcentagem de pacientes que apresentaram novamente a manifestação de um trespasse negativo. Dessa forma, verificou-se que oito pacientes apresentaram recidiva "clinicamente significante" do tratamento ortodôntico, ou seja, trespasse vertical negativo na fase T3 (TABELA 7- CAP.RESULTADOS). Portanto, $74,2 \%$ dos pacientes do grupo experimental mostraram estabilidade "clinicamente significante" da correção da mordida aberta anterior após cinco anos, do término de tratamento.

\subsection{Considerações Clínicas}

Apesar dos resultados obtidos ter demonstrado a estabilidade do tratamento com extrações, de mordidas abertas a longo prazo, o profissional deve ser cauteloso no plano de tratamento, já que demonstrou-se uma porcentagem de "recidiva clínica significante", considerando assim a necessidade do tratamento fonoaudiológico durante e após o término de tratamento. Como também o tratamento ortodôntico-cirúrgico para 
determinados casos e a necessidade de um protocolo de contenção diferente, para os casos mais exagerados.

Como demonstrado nesta pesquisa, os casos tratados foram contidos com uma placa de Hawley no arco superior e um fio colado de canino a canino ( $3 \times 3)$, sendo talvez interessante mudar esse protocolo de contenção para uma placa de Hawley com um orifício na placa para guiar o posicinamento lingual e ainda a confecção de uma contenção colada por vestibular dos incisivos inferiores, o que seria uma abordagem para futuras pesquisas.

Deve-se ainda informar muito bem ao paciente sobre todos esses aspectos, como também quanto a sua colaboração, já que nesta mecânica é imprescindível a utilização de elásticos intermaxilares e do aparelho extrabucal. Desta forma possibilitar-se-á ao clínico limitar os fatores potenciais que causam a recidiva e assim aumentar a porcentagem de sucesso desse tipo de tratamento. 
7. Conclusões 


\section{Conclusões}

De acordo com a metodologia utilizada e com os resultados obtidos em relação à estabilidade da mordida aberta, cinco anos após o tratamento com a técnica "edgewise", com extrações, na fase da dentadura permanente, parece admissível concluir que:

7.1- Quanto às características cefalométricas dos pacientes com mordida aberta, ao se comparar com o grupo controle do Atlas de crescimento facial, a nossa amostra, na fase pré-tratamento, caracterizou-se por apresentar:

- planos palatino e mandibular divergentes;

- ramo mandibular diminuído;

- padrão de crescimento acentuadamente vertical;

- incisivos superiores e inferiores acentuadamente protruídos; e apenas os superiores acentudamente inclinados para vestibular.

7.2 - Em relação à correção e à estabilidade da mordida aberta:

7.2.1 A correção da mordida aberta após o tratamento ortodôntico corretivo ocorreu mais em conseqüência da extrusão dos incisivos do que por alterações no crescimento;

7.2.1 O trespasse vertical apresentado na fase T2 apresentou um aumento estatisticamente significante, demonstrando que a mecânica utilizada nesta amostra foi eficiente para corrigir a mordida aberta;

7.2.2 A porcentagem de estabilidade "clinicamente significante" apresentou-se em $74,2 \%$. 
7.3- Quanto à correlação entre a estabilidade e os fatores esqueléticos e ou dentários:

7.3.1 Ao se correlacionar com o trespasse vertical apresentado ao início (T1) e final do tratamento (T2), observou-se uma significância estatística que, quanto menor a abertura da mordida ao início do tratamento e quanto maior o trespasse vertical obtido após o término de tratamento, maior será a estabilidade.

7.3.2 Verificou-se duas correlações estatisticamente significantes entre a alteração do trespasse na fase T3 e as grandezas cefalométricas SN.Po e BISPo; Porém clinicamente, estas correlações não se apresentaram expressivas. 


\section{Referências Bibliográficas}




\section{REFERÊNCIAS BIBLIOGRÁFICAS ${ }^{*}$}

1. AHLGREN, J. E. M. G. Studies of lip and cheek activity in sucking habits. Swed. Dent. J., v.19, n.2, p.95-101, 1995.

2. ALEXANDER, R. G.; NANDA, R.; BURSTONE, C. J. Retention and stability in orthodontics, Philadelphia, W.B. Saunders , 1993.

3. ALEXANDER, R. G. The role of oclusal forces in open-bite tratment. J. Clin. Orthodont., v.34, n.1, p.23-29, 2000.

4. ALMEIDA, R.R. et al. Mordida aberta anterior. Considerações e apresentação de um caso clínico. Rev. dent. Press Ortod. Ortop. Max. Facial, v.3, n.2, p.17-29, mar./abr.1998.

5. ALMEIDA, R.R.; URSI, W. J. S. Mordida aberta anterior. Rev. gaucha de Odontologia. v.38,n.3,p.211-8, 1990.

6. ALMEIDA, R.R.; URSI, W.J.S. Anterior open bite: etiology and treatment. Oral Health, v.80, n.1, p.27-31, Jan.1990.

7. ANDERSEN, W. S. The relation ship of the tongue-thrust sindrome to maturation and other factors. Amer. J. Orthodont., v.49, n.4, p.26475, Apr.1963.

\footnotetext{
*Normas recomendadas para uso no âmbito da Universidade de São Paulo, com base no documento "Referências Bibliográficas: exemplos", emanado do Conselho Superior do Sistema de Bibliotecas da USP, em reunião de 20 de setembro de 1990.
} 
8. ANDRADE, L.L.; RODRIGUES, J. Tratamento da síndrome do respirador bucal com mordida aberta através de aparatologia ortopédica funcional. J. bras. Ortod. Ortop. Maxilofac., v.1, n.2, p.3-13, 1996.

9. ARAT, M.; ISERI, H. Orthodontic and orthopaedic approach in the treatment of skeletal open bite. Europ. J. Orthodont., v.14, n.3, p.207-15. June. 1992.

10. ARPORNMAEKLONG, P.; HEGGIE, A. A. C. Anterior open-bite malocclusion: stability of maxillary repositioning using rigid internal fixation. Aust. Orthodont. J., v.16, n.2, p.69-81, July, 2000.

11. ARVYSTAS, M. G. Treatment of anterior skeletal open-bite deformity, Am. J. Orthodont., v.72, n. 2,p.147-64, Aug. 1977.

12. ATIKINSON, S. R. Openbite malocclusion. Am. J. Orthod. Dentofac. Orthop., v.52, n.12, p.877-86, Dec.1966.

13. BARRER, H. G. Limitation in orthodontics. Amer. J. Orthodont. , v.65, p.612-25, 1964.

14. BECKER, A.;GOULTSCHIN, J. The multistrand retainer and splint. Amer. J. Orthodont., v.85, n.6, p.470-74, June. 1984.

15. BECKMANN, S. H. et al. Alveolar and skeletal dimensions associated with overbite. Amer. J. Orthodont. Dentofac. Orthop., v.113,n.4, p.443-52, 1988. 
16. BISHARA, S. E.; TREDER, J. E.; JAKOBSEN, J. R. Facial and dental changes in adulthood. Amer. J. Orthod. Dentofac. Orthop. v.106, n.2, p.175-86, Aug. 1994.

17. BJÖRK, A Variations in the growth pattern of the human mandible: a longitudinal radiographic study by te implant method, J. dent. Res., v.42, p.400-11, 1963.

18. BJÖRK, A. Prediction of mandibular growh rotation. Amer. J. Orthodont., v.55, n.6, p.585-99,July, 1969.

19. BLAKE, M; BIBBY, K. Retention and stability: a review of the literature. Amer J Orthodont. Dentofac. Orthop., v.114, n.3, p.299-306, Sept. 1998.

20. BRANEMARK, P. I.; HANSON, B. D.; ADELL, R. Osseointegrated implants in the treatment of the edentulous jaw. Experience from a 10 year period. Scand. J. Plast. Reconstr. Surg., v.16, p.18-38, 1977.

21. BRAUN, S. Achieving improved visualizations of the temporomandibular joint condyle and fossa in the sagittal cephalogram and a pilot study of their relationships in habitual occlusion. Amer. J. Orthod. Dentofac. Orthop. v.109, n.6, p.635-8, Jun. 1996.

22. CANGIOLOSI, T. J. Skeletal morphologic features of anterior open bite. Amer. J. Orthodont., v.85, p.28-36, 1984.

23. CARVALHO, G. D. A amamentação sob a visão funcional e clínica da Odontologia. Rev. Secret. Saúde, v.2,n.10, p.12-3, 1995. 
24. CASSIDY, D. W. et al. A comparison of surgery and orthodontics in "borderline" adults with Class II, division 1 malocclusions. Amer. J. Orthod. Dentofac. Orthop. v.104, n.5, p.455-70, Nov. 1993.

25. CHANG, Y. II; MOON, S. C. Cephalometric evaluation of the anterior open bite treatment. Amer. J. Orthodont. Dentofac. Orthop., v.115, n.1, p.29-37, Jan. 1999.

26. CLEMENS, C. Prevalência de mordida aberta anterior em escolares de Porto Alegre, 1997/ Tese-Mestrado da Universidade Federal do Rio Grande do Sul/.

27. COMPOSTELA, E.A. Mordida abierta. Ortodonc. clin., v.3, n.6, p.97114, nov. 1952.

28. COSTA DEL RIO, D. Tratamiento de la mordida abierta. Rev. Esp. Estomat., v.5, n.5, p.526-38, Sept./Oct. 1957.

29. DAHLBERG, G. Statistical methods for medical and biological students. New York, Interscience, 1940.

30. DARENDELILER, M. A.; YÜKSEL, S.; MERAL, O. Open-bite correction with the Magnetic Activator Device IV. J. Clin. Orthodont., p.569575. Sept, 1995.

31. DATTILO, D. J.; BRAUN, T. W.; SOTEREANOS, G. C. The inverted L ostetomy for treatment of skeletal opne-bite deformities. J. oral Maxillofac. Surg., v.43, p.440-3, 1985.

32. DAVIS, D. W.; BELL, P. A. Infant feeding practices and occlusal outcomes: a longitudinal study. J. Canad. dent. Ass., v.57, n.7, p.593-4, 1991. 
33. DAWSON, P. E. Solving anterior opne bite probleme. In:

Evaluaton, diagnosis and tratment of oclusal problems. St Louis, The C. V. Mosby, 1974. p.322-30.

34. DE COSTER, L. Open bite. Dent. Rec., v.55, n.4, p.185-206, Apr. 1935.

35. DELLINGER, E. L. A clinical assessment of the active vertical corretor A nonsurgical alternative for skeletal open bite treatment, Amer $\mathbf{J}$. Orthodont. Dentofac. Orthop., v.89, n.5p.428-36, May. 1986.

36. DE MICHELIS, S.B.; HERTEL, A. Considerazioni eziopatogenetiche, diagnostiche e terapeutiche sul "morso aperto". Minerva stomat., v.16, n.9, p.567-80, Sept. 1967.

37. DENISON, T. F.; KOKICH, V. G.; SHAPIRO, P. A. Stability of maxillary surgery in openbite versus non-openbite malocclusions. Angle Orthodont., v.59, n.1, p.5-10, Spring, 1989.

38. DOUGHERTY, H. L. The effect of mechanical forces upon the mandibular buccal segment during orthodontic treatment. Am J. Orthodont., v.54, p.29-49, 1968.

39. DUNG, D. J.; SMITH, R. J. Cephalometric and clinical diagnoses of open bite tendency. Amer J. Orthodont. Dentofac. Orthop. , v.94, n.6, p.484-90, Dec. 1988.

40. EGOVIC, M.; OSTRIC, L. The effects of feeding methods on the grouwth of the jaws in infants. J. dent. Child., v.58, n.3, p.253-5, 1991. 
41. ElLiS, E; Mc namARA, J. A.; LAWRENCE, T. M.. Components of adult class II open bite maloclusion. J. oral Maxillofac. Surg., v.42, p.92105, 1985.

42. ENACAR, A.; UGUR, T.; TOROGLOUIS. A meted for correction of open bite. J. Clin. Orthodont. p.43-48. Jan.1996.

43. EPKER, B. N.; FISH, L. C. Surgical orthodontic corrections of openbite deformity. Amer. J. Orthodont., v.71, p.278-99, 1977.

44. ERBAY, E. et al. The effects of Frankel's function regulator (FR-4) therapy on the treatment of Angle Class I skeletal anterior open bite malocclusion. Amer. J. Orthodont. Dentofac. Orthop., v.108, p.921, July. 1995.

45. FERRE, J. C. Treitment dês beances frontales anterioures a l'aide $d$ la methode de Ricketts. ( A propos de deux cas ). Acta Stomat. Belg., v..72, n.4, p.619-28,1975.

46. FERREIRA, F. V. Ortodontia: diagnóstico e planejamento clínico. São Paulo, Artes médicas, 1997.

47. FIELDS, H. W. et al. Facial pattern differences in long-faced children and adults. Amer. J. Orthodont., v.85, p.217-23, 1984.

48. FOTIS, V. et al. Verical control as an important ingredient in the treatment of severe sagital discrepancies. Amer. J. Orthodont., v.86, p.224-32, 1984.

49. FRANKEL, R.; FRANKEL, C. A functional approach to treatment of skeletal open bite. Amer. J. Orthodont., v.84, n.1, p..54-68, July 1983. 
50. FRÄNKEL, R.; FRÄNKEL, C. Orofacial orthopedics with the function regulator. New York, Karger, 1989.

51. FREITAS, M. R. de; MARTINS, D. R. Estudo cefalométrico da ancoragem inferior, em pacientes tratados com a técnica de Martins e com preparo de ancoregem (Tweed), estudo analítico e comparativo. Ortodontia, v.16, n.1, p.5-17, jan./abr. 1983.

52. FROST, D.E. et al. Cephalometric diagnosis and surgical orthodontic correction of apertognathia. Amer J. Orthodont., v.73, p.657-69, 1980.

53. GARLINER, D. Myofunctional therapy: an aid in the practice of orthodontics, Amer. Ass. Orthodont., slide tape program.p.225-270.

54. GERSHATER, M. The proper perspective of openbite. Angle Orthodont., v.23, n.3, p.263-72, July 1972.

55. GILE, R. A. A longitudinal cephalometric evaluation of orthodontically treated anterior openbite cases. Washington, 1972. Dissertation (Master)- University of Washington

56. GOTO, S.; BOYD, R. L.; IIZUKA, T. Case report: nonsurgical treatment of an adult with severe anterior open bite. Angle Orthodont., v.64, n.4, p.311-8, 1994.

57. GRABER, T. M. The finger sucking habit and associated problems. J. dent. Children, v.25, p.145-51, 1958.

58. GRABER, T. M. Current orthodontic concepts and techniques, Philadelphia, W.B. Saunders, 1969 
59. HAPAK, F. M. Cephalometric apraisal of the opnebite case. Angle Orthodont., v.34, n.1, p.65-72, Jan.1964.

60. HARRIS, E. F. Patterns of incisor root resorption before and after orthodontic corretion in cases with anterior open bites. Amer. J. Orthodont. Dentofac. Orthop. v.101, p.112-9, Feb. 1992.

61. HERZBERG, R. A cephalometric study of class II relapse. Angle Orthodont., v.43, n.1, p.112-8, Jan. 1973.

62. HINDS, E. C. ; KENT, J. N. Diagnosis and selection of surgical procedures in management of open bite J. oral Surg., v.27, p.93949, 1969.

63. HUANG, G. J. et al. Stability of anterior openbite treated with crib therapy. Angel Orthodont., n.1, p.17-26, 1990.

64. ISAACSON, J. R. et al. Extreme variation in the vertical facial growth and associated variations in skeletal and dental relations. Amer. J. Orthodont., v.41, p.219-29. 1971.

65. ISCAN, H. N.; AKKAYA, S.; KORALP, E. The effects of the springloaded posterior bite-block on the maxillo-facial morphology. Europ. J. Orthodont., v.14, p.54-60, 1992.

66. JABUR, L. B. Avaliação fonoaudiológica. In: FERREIRA, F. V. Ortodontia: diagnóstico e planejamento clínico. São Paulo, Artes médicas, 1997. Cap.14, p.273-301.

67. JANSON, G.R. P.; METAXAS, A.; WOODSIDE, D. G. Variations in maxillary and mandibular molar and incisor vertical dimension in 12year-old subjects with excess, normal, and short lower anterior face 
height. Amer. J. Orthodont. Dentofac. Orthop., v.106, n.4, p.40918, Oct. 1994.

68. JANSON, G. R. P. Estudo tridimensional das assimetrias dentárias e esqueléticas na má oclusão de Classe II, subdivisão. Bauru, 1998. 271p. Tese (Livre-Docência) - Faculdade de Odontologia de Bauru, Universidade de São Paulo.

69. JUSTUS, R. Tratamiento de la mordida abierta anterior; um estudio cefalometrico y clinico. Rev. Ass. dent. Mex., v.33, p.17-40. 1976.

70. KAJIWARA, T. Morphological study of openbiteskeletal class openbite. J. Jpn. Orthodont. Soc., v.51, n.4, p. 40-52, 1992.

71. KIM, Y. H. Anterior openbite and its treatment with multiloop Edegewis archwire. Angle Orthodont., v.57, n.4, p.290-321, Oct.1987.

72. KIM, Y. H. Stability of anterior openbite correction with multiloop edgewise archwire therapy: a cephalometric follow-up study. Amer. J. Orthodont. Dentofac. Orthop., v.118, n.1, p.43-54, 2000.

73. KROGMAN, W. N.; SASSOUNI, V. A. A. Syllabus in roentgenographic cephalometry. Philadelphia, Philadelphia Center for Research in Child Growth, 1957. p.45-103

74. KÜÇÜKKELES, N. et al. Cephalometric evaluation of open bite tratament with $\mathrm{NiTi}$ arch wires and anterior elastics. Amer. J. Orthodont. Dentofac. Orthop., v.116, n.5, p.555-62, 1999.

75. KUHN, R. Control of anterior vertical dimension and proper selection of extraoral anchorave. Angle Orthodont., v.38, p.340-50, 1968. 
76. LEE, B. W. Case report - treatment of anterior open bite with tongue thrust and associated temporo-mandibular joint symptoms. Aust. Orthodont. J., p.246-9, Mar. 1993.

77. LEGAN, H. L.; BURSTONE, C. J. Soft tissue cephalometric analysis for orthognatic surgery. J. oral. Surg., v.38, n.10, p.744-51, Oct. 1980.

78. LIEBERMAN, M. A.; GAZIT, E. Correction of a Class I skeletal open-bite malocclusion. Angle Orthodont., v.48, n.3, p.206-9, 1978.

79. LINDER-ARONSON, S. Adenoids: their effect on mode of breathing and nasal airflow and their relationship to characteristics of the facial skeleton and dentition. Acta otolaryng. Scand. 1970. (Supplement)

80. LINDER-ARONSON, S. Effects of adenoidectomy on the dentition and facial skeleton over a period of five years. In: Cook, J.T., ed. Transactions of the Third International Orthodontic Congress. St. Louis, Mosby, 1975.

81. LOPEZ-GAVITO, G. et al. Anterior open bite malocclusion: a longitudinal 10 year postretention evaluation of orthodontically treatded patients. Amer. J. Orthodont., v.87, n.3, p.175-86, Mar. 1985.

82. LOWE, A. A. Neuromechanisms involved intongue moyility. Canada, Toronto, 1976. Dissertation (Master) - Departament of Dentistry, University of Toronto.

83. MARKUS, M. B. The review and consideration of the problem of retention, Amer. J. Orthodont. oral Surg.,v.24, p.203-7, 1958.

84. MARTINS, D. R. et al. A mordida aberta anterior: conceitos, diagnóstico e tratamento- Parte I. Odontomaster, v.1, n.5, p.105-33, 1994. 
85. MARTINS, D. R. et al. Atlas de crescimento craniofacial. São Paulo, Ed. Santos, 1998. 280p.

86. MC NAMARA, J. A. An experimental study of increased vertical dimension in the growing face. Amer. J. Orthodont., v.71, p.382-95. 1977.

87. MC NAMARA, J. A. A method of cephalometric evaluation. Amer. J. Orthodont., v.86, n.6, p.449-69. Dec. 1984.

88. MC NEIL, W. R.; HOOLEY, J. R.; SUNDBERG, R. I. Skeletal relapse during intermaxillary fixation. J. oral Surg., v.31, p.212-27, 1973.

89. MODESTO, A.; AZEVEDO, G. T. Habito de sucção de polegar: como descontinuá-lo ? Rev. . v.5, n.2 p.41-8, 1997.

90. MODÉER, T.; ODERNICK, L.; LINDNER, A. Sucking habits and their relation to posterior cross-bite in 4 year-old children. Scand. J. dent. Res., v.90, n.4, p.323-8, 1982.

91. MOSS, J. P. et al. A three-dimensional study of treatment with magnet and non-magnet twin-blocks (abstr.). Europ. J. Orthodont., v.15,p.342,1993.

92. MOYERS, R. E. Handbook of orthodontics. 4.ed, USA, Year Book Medical Publishers, 1988. p.152-155,196-218.

93. MOYERS, R. E. Etiologia da má oclusão. In: Ortodontia. 4 ed. Rio de Janeiro, Guanabara Koogan, 1991. Cap.7,p.131-4.

94. NAHOUM, H. I. Vertical proportions and palatal plane in anterior openbite. Amer. J. Orthodont., v.59, n.3, p.273-82, Mar. 1971. 
95. NAHOUM, H. I. Anterior open bite: a cephalometric analysis and suggested treatment procedures. Amer. J. Orthodont., v.67, p.51321, 1975.

96. NAHOUM, H. I. Vertical proportions: a guide for prognosis and treatment in anterior open-bite. Amer. J. Orthodont., v.72, n.2, p.128-46. Aug. 1977.

97. NAHOUM, H. I.; HOROWITZ, S. L.; BENEDICTO, E. Varieties of anterior open bite. Amer. J. Orthodont., v.61,n.5,p.486-92, May 1972.

98. NANDA, S. K. Patterns of vertical growth in the face. Amer. J. Orthodont. Dentofac. Orthop., v.93, p.103-16, Feb. 1988.

99. NANDA, S. K. Growth patterns in subjects with long and short faces. Am. J. Orthodont. Dentofac. Orthop., v.98, p.249-58, 1990.

100. NANDA, R. S.; NANDA, S. K. Considerations of dentofacial growth in long-term retention and stability: is active retention needed ? Amer. J. Orthodont. Dentofac. Orthop., v.101, n.4, p. 297-302, Apr. 1992.

101. NEMETH, R. B.; ISAACSON, R. J. Vertical anterior relapse. Amer. J. Orthodont. Dentofac. Orthop. v.65, p.565-85, 1974.

102. NGAN, P.; FIELDS, H.W. Open bite: areview of etiology and management. Pediat. Dent., v.19, n.2, p.91-8, 1997.

103. NIELSEN, I. L. Vertical malocclusions: etiology, development, diagnosis and some aspects of treatment. Angle Orthodont., n.4, p.247-260. 1991. 
104. OGAARD, B. et al. The effect of suckinghabits, cohort, sex, intercanine arch widths and breast bottle feeding on posterior crossite in Norwegian and Swedish 3-years-old children. Amer. J. Orthodont. Dentofac. Orthop., v.106 n.2, p.106-61, Aug.1994.

105. OSBORN, D. B. Bonded lingual retainers. Amer. J. Orthodont., v.83, n.3, p.218-20, Mar. 1983.

106. OZAWA, T. O.et al. Controle vertical em ortodontia com o uso de "biteblock". Rev. SPO-Ortodontia, v.31, n.2, p.81-90, 1998.

107. PANCHERZ, $\mathrm{H}$. The nature of Class II relapse after Herbst appliance treatment: a cephalometric long-term investigation. Amer. J. Orthodont., v.100, n.3, p.220-33, Sept. 1991.

108. PARRA, N. L. S. Mordida aberta anterior. Estudo de pacientes tratados ortodonticamente e cinco anos pós-contenção. Disponível na Internet. http://www.odontologia.com.br/artigos. Data de acesso ao site. fev.2001, p.1-14,abr. 2000.

109. PAUNIO, P. et al. The finish family competency study: the effects of living conditions on sucking habits in 3-years-old children and the assoiation between these habits and dental occlusion. Acta Odontol. Scand., v.51,n.1, p.23-9, 1993.

110. PEARSON, L. E. Vertical control in treatment of patients having backward-rotational growth tendencies. Angle Orthodont., v.48, p.132-40, 1978.

111. PEQUEÑO BOTARRO, J. et al. Tratamientos de mordidas abiertas com planos oclusales de goma. Odont. Chil., v.21, n.110, p.35-44, jul./dic. 1973. 
112. POLLARD, L. E.; MAMANDRAS, A. H. Male postpubertal facial growth in Class II malocclusions. Amer. J. Orthod. Dentofac. Orthop. v.108, n.1, p.62-8, Jul. 1995.

113. POULTON, D. R.; WARE, W. H. Surgical-orthodontic treatment of severe mandibular retrusion. Amer J. Orthodont., v.59, p.244-65, 1971.

114. PROFFIT, W. R.; MASON, R. M. Myofunctional terapy for tongue thrusting: background and recommendations. J. Amer. dent. Ass., v.90, p.403-11, 1975.

115. PROFFIT, W. R. Contemporany orthodontics. Saint Louis, Mosby 1986. p. $455-70$.

116. PROSTERMAN, B. et al. The use of implants for orthodontic correctio of an open bite. Amer. J. Orthodont. Dentofac. Orthop., v.107, n.3, p.245-50, Mar. 1995.

117. QUINN, G. W. Airway interference and its effect upon the growth and development of the face, jaws, dentition and associeted parts. N.C. Dent. J., v.60, p.28-31, 1978.

118. REIDEL, R. A. In: GRABER, T. M., SWAIN, B. F. Current orthodontic concepts and techniques. Philadelphia, Saunders, 1969. p.875918.

119. REIKIK, M. The surgical treatmnt of skeletal anterior open-bite deformities with rigid internal fixation in the mandible, Amer. J. Orthodont. Dentofac. Orthop., v.97, p.52-7, 1990. 
120. REIN, B. Treatment of anterior open bite malocclusions. Int. J. Orthodont., v.7, n.1, p.27-34, Mar. 1969.

121. REITAN, K. Principles of retention and avoidance of post-treatment relapse. Amer. J. Orthodont. Dentofac. Orthop., v.55, n.4, p.296302, Oct. 1969.

122. REYNECE, J. P. Surgical cephalometric prediction tracing for the alteretion of the oclusal plane by means of rotation and the maxlomandibular complex, Int. J. Adult Orthodont. Orthognat. Surg., v.14, p.55-64,1999.

123. RICHARDSON, A. R. Dento- alveoalar factors in anterior open bite and deep over bite. Dent. Practit. dent. Rec. v.21, p.53-57, 1970.

124. RICHARDSON, A. R. A classification of open bites. Europ. J. Orthodont., v.3, p.29-296, 1981.

125. RICKETTS, R. M. Respiratory obstructions syndrome, in Forum on the tosil and adenoid problems in orthodontics. Amer. J. Orthodont., v.78, p.495-514, 1968.

126. ROBLES, F. R. P. et al. A influência do período de amamentação nos hábitos de sucção persistentes e a ocorrência de má oclusões em crianças com dentição decídua completa. Rev. paul. Odont., v.31, n.3, maio/jun.1999.

127. ROGERS, A.P. Open bite cases involving tongue habits. Int. J. Orthodont., v.13, p.8-37, 1927. 
128. ROWLEY, R. et al. An investigation of the association between anterior open-bite and amelogenesis imperfecta. Amer. J. Orthodont., p.229-35, Mar. 1982

129. RUBIN, R. M. The effects of nasal airway obstruction. Amer. J. Orthodont., v.78, p.504-10, 1983

130. SASSOUNI, V. A Classification of skeletal facial types. Amer. J. Orthodont., v.55, n.2, p.109-23, Feb. 1969.

131. SCHENDEL, S. A. et al. The longe face syndrome: vertical maxilary surgery. Amer. J. Orthodont., v.70, p.398-408, 1977.

132. SCHUDY, F. F. The rotation of the mandible resulting from growth: its implication in orthodontic treatment. Angle Orthodont., v.35, p.3650. 1965.

133. SCHUDY, F. F. Verical growth versus anteroposterior growth and function and treatment. Angle Orthodont., v.34, p.75-93. 1964.

134. SERRA NEGRA, J. M. C. et al. Estudo da associação entre aleitamento, hábitos bucais e maloclusões. Rev. Odont. USP, v.11, n.2, p.79-86, abr./jun. 1997.

135. SILVA FILHO, O. G.; OKADA, T.; SANTOS, S. D. Sucção digitalabordagem multidisciplinar: Ortodontia $X$ Psicologia $X$ Fonoaldiologia. Estomat. Cult., v.16, n.2, p.44-52, 1986.

136. SILVA, F.O.G.; FREITAS, S.E.; CAVASSAN, A.O. Prevalência da oclusão normal em escolares da cidade de Bauru (São Paulo). Parte II: Influência da estratificação sócio econômica. Rev. Odont. Univ. São Paulo, v.4, n.3, p.189-96, jul./set. 1990. 
137. SPEIDEL, T. M.; ISAACSON, R. J.; WORMS, F. W. Tongue thrust therapy and anterior dental openbite. Am. J. Orthodont., St. Louis, v.62, n.3, p.287-95, Sep. 1972.

138. SPYROPOULOS, M. N. Na early approach for the interception of skeletal open bites: a preliminary report, J. Pedod., v.9, p.200-9, 1985.

139. STAGGERS, J. A. Vertical changes following first premolar extractions. Amer. J. Orthodont. Dentofac. Orthop., v.105, n.1, p.19-24, Jan. 1994.

140. STEINER, C. Cephalometrics for you and me. Amer. J. Orthodont., v. 39, n.10, p.729-55, Oct. 1953.

141. STRAUB, W. Malfunction of the tongue. Part. I. The abnormal swallowing habit: its causes, effects, and results in reaction to orthodontic treatment and speech therapy. Amer. J. Orthodont., v.46, n.404, 1960.

142. SUBTELNY, J. D. Openbite: diagnosis and treatment. Amer. J. Orthodont. Dentofac. Orthop., v.50, p.337-58, 1964.

143. SUBTELNY, J. D.; SUBTELNY, J. D. Open bite treatment. In: Internacional orthodontic Congress. London, p.13-18, Aug. 1973. Transactions. St. Louis, Mosley, 1975. p.432-45.

144. SUBTELNY, J. D.; SUBTELNY, M. K. Oral habits: studies in form, function and therapy. Angle Orthodont., v.43, n.4, p.347-383, Oct.1973. 
145. SUBTELNY, J.D.; SAKUDA, M. Open bite: diagnosis and treatment. Amer. J. Othodont., v.50, n.5, p.337-58, May 1964.

146. SWINEHEART, E. W. a clinical study of open bite. Oral Surg., v.28, p.18-34, 1942.

147. TOMES, C. S. On the developmental origin of the v-shapel contracted maxlilla. Manthly Rev. dent. Surg., v.1, p.2-5, 1872.

148. UEDA, H. M. et al. Relationship between masticatory muscle activity and vertical craniofacial morfology, Angle Orthodont., v.68, p.233-8, 1998.

149. VAN DER LAAN, T. A. A importância da amamentação no desenvolvimento facial infantil. Pro-Fono Rev. Atual Cient., v.7, n.1, p.18-24, 1995.

150. VAN DER LINDER, F. P. G. M. O desenvolvimento da dentição em mordidas abertas. In: Ortodontia: desenvolvimento da dentição. São Paulo, Qintessence, 1986. Cap.13, p.115-20.

151. VATTEONE, A.L. Mordida abierta: formas clínicas y tratamiento. Rev. Circ. argent. odont. v.32, n.2, p.17-22, May 1969.

152. WATSON, W. G. Openbite a multifactorial event. Amer. J. Orthodont. Dentofac. Orthop., v.80, n.4, p.443-6, Oct. 1991.

153. WILLIAMSON, E. H. Treatment of temporomandibular joint dysfunction and bilateral posterior open bite. Fac. Orthop. Temporomandibular Arthrol., v.2, n.10, p.9-13, Oct. 1985 
154. WOODS, M.G.; NANDA, R.S. Intrusion of posterir teeth with magnets: an experiment in nongrowing baboons. Amer. J. Othodont., v.100, n.5, p.393-400, Nov. 1991.

155. WORMS, F. W.; MESKIN, L. H.; ISACSSON, R. J. Openbite. Amer. J. Orthodont., v.59, n.6, p.589-95, June 1971

156. YAMAGUCHI, K.; NANDA, R. S. The effects of extraction and nonextraction treatment on the mandibular position. Amer. J. Orthodont. Dentofac. Orthop., v.100, p.443-52, Nov. 1991.

157. WALteR, L. R. F.; FERELLE, A.; ISSAO, M. Hábitos. In 3/4 Odontologia para o bebê. São Paulo, Artes Médicas, 1996. p.8384.

158. WEINBACH, J. R.; SMITH, R. J. Cephalometric changes during treatmnt with the open bite bionator. Amer. J. Orthodont. Dentofac. Orthop., v.101, p.367-74, 1992. 


\section{Abstract}




\section{ABSTRACT}

This study aimed at cephalometrically evaluating the open bite stability after five years of treatment, as well as the correlation of this study with possible skeletal and dental alterations. Thus, 93 teleradiographs of 31 patients were used, comprising a single treated group, assessed in three phases: initial, final and five years following posttreatment. A Class I and II malocclusion control group, longitudinally studied by MARTINS was compared, being the data kept in the growth Atlas at the Dental School, USP, at Bauru, SP. Initially, all patients presented an anterior open bite greater than $1 \mathrm{~mm}$, when measured in models, with Class I and II malocclusions in the permanent denture phase and were orthodontically treated with fixed appliances through the Edgewise technique with extractions. These patients were selected from the archives of the Orthodontics Discipline at the Dental School - USP, at Bauru, SP, and when initially compared with the control group, presented: divergent palatine and mandibular planes; a diminished mandibular ramus; an increased antero inferior facial height; a markedly vertical growth pattern; highly protruded upper and lower incisors and only the upper markedly tipped to the vestibular.

All results were submitted to statistical analysis, revealing that the mechanics employed showed to be quite effective in correcting this vertical displasia. After 5 years of treatment, the anterior open bite presented a stability of $74.2 \%$. The skeletal (FMA, Ar.GoMe, Ar-Go, S-Go, AFAT, AFAI), and dental (IMPA, BII-NB, 1I.NB, 6S-PP, 6I-GoMe) measures demonstrated statistically significant alterations which corroborated to this stability, and following the correlation of vertical overlap obtained 5 years of posttreatment with the initial vertical overlap, it is also concluded that the smaller the initial open bite, the greater the stability after 5 years of treatment, and that the greater the vertical overlap obtained after treatment, the smaller the relapse. 
Apêndice 
Anexo I- Tabelas das medidas esqueléticas e dentárias individuais

1- Medida SNA

\begin{tabular}{|c|c|c|c|c|c|}
\hline Pacientes & SNA t1 & SNA t2 & SNA t3 & SNA2-1 & SNA3-2 \\
\hline A.F.S. & 77,3 & 79,4 & 78,3 & 2,1 & $-1,1$ \\
\hline A.S. & 85,2 & 83,9 & 82,3 & $-1,3$ & $-1,6$ \\
\hline A.A. M. & 86,2 & 84,2 & 82,4 & -2 & $-1,8$ \\
\hline A. R. Jr. & 82,2 & 82,4 & 80,5 & 0,2 & $-1,9$ \\
\hline A.A. Jr. & 81,4 & 80,5 & 81,2 & $-0,9$ & 0,7 \\
\hline C. C. 0 . & 76,3 & 77,3 & 78,3 & 1 & 1 \\
\hline C. M.R. & 77,3 & 78 & 78,5 & 0,7 & 0,5 \\
\hline D. S. M. & 79 & 80,8 & 78,8 & 1,8 & -2 \\
\hline E.D.P.F. P. & 83,4 & 83,8 & 83,1 & 0,4 & $-0,7$ \\
\hline F.C. & 79,6 & 82,5 & 81,3 & 2,9 & $-1,2$ \\
\hline J.R. T. & 81,2 & 82,2 & 80,5 & 1 & $-1,7$ \\
\hline J. C.A.O. & 87,3 & 86,4 & 87,7 & $-0,9$ & 1,3 \\
\hline K.C. & 90,3 & 83,5 & 83,2 & $-6,8$ & $-0,3$ \\
\hline L. F. & 76,9 & 75,9 & 78 & -1 & 2,1 \\
\hline M. S. R. & 76,4 & 77,1 & 75,3 & 0,7 & $-1,8$ \\
\hline M. R.F. & 80,2 & 80,3 & 82,3 & 0,1 & 2 \\
\hline M. P. & 80,9 & 80,7 & 81,7 & $-0,2$ & 1 \\
\hline M. S. G. & 74,7 & 73,7 & 73,3 & -1 & $-0,4$ \\
\hline M. A. & 81,6 & 77,4 & 74,3 & $-4,2$ & $-3,1$ \\
\hline M. C. & 79,8 & 76,6 & 73,3 & $-3,2$ & $-3,3$ \\
\hline M. A. & 76,2 & 79,5 & 82 & 3,3 & 2,5 \\
\hline M. C. & 77,6 & 74,2 & 74,5 & $-3,4$ & 0,3 \\
\hline M. A. G. & 82,8 & 78,9 & 83,6 & $-3,9$ & 4,7 \\
\hline N. M. & 80,8 & 82,4 & 80,9 & 1,6 & $-1,5$ \\
\hline R. M. & 79,5 & 79,9 & 78,4 & 0,4 & $-1,5$ \\
\hline R. J.L.G. & 81,6 & 81,6 & 80,8 & 0 & $-0,8$ \\
\hline R. W. & 82,1 & 81,2 & 80,8 & $-0,9$ & $-0,4$ \\
\hline S. M. & 76 & 76,3 & 77,1 & 0,3 & 0,8 \\
\hline S. F. C. & 74,7 & 75,5 & 73,5 & 0,8 & -2 \\
\hline T. G. S. & 72,6 & 74 & 73,4 & 1,4 & $-0,6$ \\
\hline V. G. & 83,3 & 81,3 & 81,7 & -2 & 0,4 \\
\hline
\end{tabular}




\section{2- Medida SNB}

\begin{tabular}{|c|c|c|c|c|c|}
\hline Pacientes & SNB t1 & SNB t2 & SNB t3 & SNB2-1 & SNB3-2 \\
\hline A.F.S. & 75,4 & 75,6 & 75,8 & 2,1 & 0,2 \\
\hline A.S. & 79,4 & 78,9 & 77,7 & $-1,3$ & $-1,2$ \\
\hline A.A. M. & 80,7 & 80,6 & 80,2 & -2 & $-0,4$ \\
\hline A. R. Jr. & 76,6 & 75,9 & 75,9 & 0,2 & 0 \\
\hline A.A. Jr. & 79,1 & 77,8 & 80,2 & $-0,9$ & 2,4 \\
\hline C. C. 0 . & 71 & 73,5 & 76,3 & 1 & 2,8 \\
\hline C. M.R. & 76,1 & 76,2 & 76,2 & 0,7 & 0 \\
\hline D. S. M. & 77,9 & 78,8 & 78,5 & 1,8 & $-0,3$ \\
\hline E.D.P.F. P. & 79,9 & 81,5 & 81,1 & 0,4 & $-0,4$ \\
\hline F. C. & 75,8 & 76,3 & 75,7 & 2,9 & $-0,6$ \\
\hline J.R. T. & 75,8 & 76,2 & 74,7 & 1 & $-1,5$ \\
\hline J. C.A.O. & 86,1 & 85,3 & 85,8 & $-0,9$ & 0,5 \\
\hline K.C. & 85,1 & 83,8 & 82,5 & $-6,8$ & $-1,3$ \\
\hline L. F. & 73,4 & 72,2 & 73,1 & -1 & 0,9 \\
\hline M. S. R. & 74,3 & 72,5 & 71,3 & 0,7 & $-1,2$ \\
\hline M. R.F. & 75,2 & 75,5 & 76 & 0,1 & 0,5 \\
\hline M. P. & 72,7 & 76,6 & 73,4 & $-0,2$ & $-3,2$ \\
\hline M. S. G. & 72,7 & 73,7 & 71,3 & -1 & $-2,4$ \\
\hline M. A. & 76 & 73,2 & 71,5 & $-4,2$ & $-1,7$ \\
\hline M. C. & 73,3 & 71,6 & 69,6 & $-3,2$ & -2 \\
\hline M. A. & 77,4 & 77,3 & 77,9 & 3,3 & 0,6 \\
\hline M. C. & 75,1 & 74,2 & 74,6 & $-3,4$ & 0,4 \\
\hline M. A. G. & 76 & 76,4 & 76,1 & $-3,9$ & $-0,3$ \\
\hline N. M. & 78,1 & 76,6 & 76,2 & 1,6 & $-0,4$ \\
\hline R. M. & 76,9 & 77,3 & 76,4 & 0,4 & $-0,9$ \\
\hline R. J.L.G. & 77,6 & 79,3 & 79,4 & 0 & 0,1 \\
\hline R. W. & 76,6 & 76,5 & 76,8 & $-0,9$ & 0,3 \\
\hline S. M. & 76 & 77,3 & 78,8 & 0,3 & 1,5 \\
\hline S. F. C. & 70,5 & 70,6 & 68,9 & 0,8 & $-1,7$ \\
\hline T. G. S. & 69,7 & 69,6 & 71,2 & 1,4 & 1,6 \\
\hline V. G. & 77,5 & 74,9 & 75,1 & -2 & 0,2 \\
\hline
\end{tabular}


3- Medida ANB

\begin{tabular}{|c|c|c|c|c|c|}
\hline Pacientes & ANB t1 & ANB $t 2$ & ANB t3 & ANB 2-1 & ANB 3-2 \\
\hline A.F.S. & 1,8 & 3,8 & 2,5 & 2 & $-1,3$ \\
\hline A.S. & 5,8 & 5 & 4,6 & $-0,8$ & $-0,4$ \\
\hline A.A. M. & 5,5 & 3,6 & 2,2 & $-1,9$ & $-1,4$ \\
\hline A. R. Jr. & 5,6 & 6,4 & 4,6 & 0,8 & $-1,8$ \\
\hline A.A. Jr. & 2,3 & 2,8 & 1 & 0,5 & $-1,8$ \\
\hline C. C. 0 . & 5,3 & 3,9 & 2 & $-1,4$ & $-1,9$ \\
\hline C. M.R. & 1,1 & 1,8 & 2,3 & 0,7 & 0,5 \\
\hline D. S. M. & 1 & 2 & 0,3 & 1 & $-1,7$ \\
\hline E.D.P.F. P. & 3,5 & 2,3 & 2 & $-1,2$ & $-0,3$ \\
\hline F. C. & 3,8 & 6,3 & 5,6 & 2,5 & $-0,7$ \\
\hline J.R. T. & 5,4 & 6 & 5,8 & 0,6 & $-0,2$ \\
\hline J. C.A.O. & 1,2 & 1 & 1,8 & $-0,2$ & 0,8 \\
\hline K.C. & 5,2 & $-0,4$ & 0,7 & $-5,6$ & 1,1 \\
\hline L. F. & 3,6 & 3,7 & 4,9 & 0,1 & 1,2 \\
\hline M. S. R. & 2 & 4,6 & 4 & 2,6 & $-0,6$ \\
\hline M. R.F. & 5,1 & 4,8 & 6,3 & $-0,3$ & 1,5 \\
\hline M. P. & 8,1 & 4,2 & 8,2 & $-3,9$ & 4 \\
\hline M. S. G. & 2 & 0 & 2 & -2 & 2 \\
\hline M. A. & 5,7 & 4,2 & 2,9 & $-1,5$ & $-1,3$ \\
\hline M. C. & 6,5 & 5,1 & 3,7 & $-1,4$ & $-1,4$ \\
\hline M. A. & $-1,2$ & 2,3 & 4,1 & 3,5 & 1,8 \\
\hline M. C. & 2,5 & 0 & $-0,1$ & $-2,5$ & $-0,1$ \\
\hline M. A. G. & 6,8 & 2,5 & 7,4 & $-4,3$ & 4,9 \\
\hline N. M. & 2,7 & 5,7 & 4,7 & 3 & -1 \\
\hline R. M. & 2,6 & 2,6 & 2,1 & 0 & $-0,5$ \\
\hline R. J.L.G. & 4 & 2,3 & 1,4 & $-1,7$ & $-0,9$ \\
\hline R. W. & 5,5 & 4,7 & 4 & $-0,8$ & $-0,7$ \\
\hline S. M. & 0 & $-0,9$ & $-1,7$ & $-0,9$ & $-0,8$ \\
\hline S. F. C. & 4,2 & 4,9 & 4,6 & 0,7 & $-0,3$ \\
\hline T. G. S. & 2,8 & 4,4 & 2,1 & 1,6 & $-2,3$ \\
\hline V. G. & 5,8 & 6,4 & 6,5 & 0,6 & 0,1 \\
\hline
\end{tabular}




\section{4- Medida SN.GoGN}

\begin{tabular}{|c|c|c|c|c|c|}
\hline Pacientes & SN.GoGn t1 & SN.GoGn t2 & SN.GoGn t3 & SN.GoGn2-1 & SN.GoGn3-2 \\
\hline A.F.S. & 41,8 & 42,9 & 35,4 & 1,1 & $-7,5$ \\
\hline A.S. & 33,6 & 36,1 & 35,6 & 2,5 & $-0,5$ \\
\hline A.A. M. & 35,7 & 33,8 & 32,9 & $-1,9$ & $-0,9$ \\
\hline A. R. Jr. & 39,6 & 38,5 & 33,6 & $-1,1$ & $-4,9$ \\
\hline A.A. Jr. & 36,8 & 39,3 & 38 & 2,5 & $-1,3$ \\
\hline C. C. 0 . & 46,1 & 43,1 & 42,4 & -3 & $-0,7$ \\
\hline C. M.R. & 35,1 & 35 & 35 & $-0,1$ & 0 \\
\hline D. S. M. & 38 & 37 & 37,1 & -1 & 0,1 \\
\hline E.D.P.F. P. & 36,3 & 34,4 & 34 & $-1,9$ & $-0,4$ \\
\hline F.C. & 41,6 & 43,6 & 40,7 & 2 & $-2,9$ \\
\hline J. R. T. & 41,7 & 40,8 & 40 & $-0,9$ & $-0,8$ \\
\hline J. C.A.O. & 31,2 & 30,6 & 30,4 & $-0,6$ & $-0,2$ \\
\hline K.C. & 32,3 & 31,7 & 32,3 & $-0,6$ & 0,6 \\
\hline L. $F$. & 42,8 & 44,4 & 44 & 1,6 & $-0,4$ \\
\hline M. S. R. & 38,8 & 38,6 & 39,4 & $-0,2$ & 0,8 \\
\hline M. R.F. & 37,6 & 37 & 36,6 & $-0,6$ & $-0,4$ \\
\hline M. P. & 36 & 37,9 & 42,1 & 1,9 & 4,2 \\
\hline M. S. G. & 45,2 & 45,7 & 46,6 & 0,5 & 0,9 \\
\hline M. A. & 41,1 & 43,2 & 43,7 & 2,1 & 0,5 \\
\hline M. C. & 42,1 & 45,8 & 47,9 & 3,7 & 2,1 \\
\hline M. A. & 37,1 & 36,1 & 35,2 & -1 & $-0,9$ \\
\hline M. C. & 35,2 & 35,9 & 36,5 & 0,7 & 0,6 \\
\hline M. A. G. & 38,5 & 39,2 & 37,7 & 0,7 & $-1,5$ \\
\hline N. M. & 35,6 & 38,5 & 40 & 2,9 & 1,5 \\
\hline R. M. & 41,2 & 40,1 & 40,7 & $-1,1$ & 0,6 \\
\hline R. J.L.G. & 43 & 42 & 42,2 & -1 & 0,2 \\
\hline R. W. & 40,1 & 40,7 & 39,6 & 0,6 & $-1,1$ \\
\hline S. M. & 35,4 & 37 & 35,8 & 1,6 & $-1,2$ \\
\hline S. F. C. & 47,6 & 48,3 & 48,2 & 0,7 & $-0,1$ \\
\hline T. G. S. & 46,6 & 45,5 & 41,7 & $-1,1$ & $-3,8$ \\
\hline V. G. & 38,7 & 40,8 & 40,8 & 2,1 & 0 \\
\hline
\end{tabular}




\section{5- Medida FMA}

\begin{tabular}{|c|c|c|c|c|c|}
\hline Pacientes & FMA t1 & FMA t2 & FMA t3 & FMA t2-t1 & FMA 3t-t2 \\
\hline A.F.S. & 35,9 & 37,1 & 26,6 & 1,2 & $-10,5$ \\
\hline A.S. & 26,8 & 26,5 & 26 & $-0,3$ & $-0,5$ \\
\hline A.A. M. & 18,2 & 29,8 & 27,8 & 11,6 & -2 \\
\hline A. R. Jr. & 32,4 & 19,3 & 25,2 & $-13,1$ & 5,9 \\
\hline A.A. Jr. & 27,3 & 29,4 & 32,5 & 2,1 & 3,1 \\
\hline C. C. 0. & 38,7 & 36,9 & 32,6 & $-1,8$ & $-4,3$ \\
\hline C. M.R. & 26,2 & 26,8 & 26,4 & 0,6 & $-0,4$ \\
\hline D. S. M. & 33,3 & 32,2 & 31,8 & $-1,1$ & $-0,4$ \\
\hline E.D.P.F. P. & 24,1 & 23,9 & 22 & $-0,2$ & $-1,9$ \\
\hline F. C. & 29,4 & 32,3 & 27,3 & 2,9 & -5 \\
\hline J. R. T. & 33 & 34,4 & 29,7 & 1,4 & $-4,7$ \\
\hline J. C.A.O. & 24,6 & 24,9 & 23,2 & 0,3 & $-1,7$ \\
\hline K.C. & 21,5 & 19,1 & 19,1 & $-2,4$ & 0 \\
\hline L. F. & 32,9 & 35,4 & 35,5 & 2,5 & 0,1 \\
\hline M. S. R. & 32,7 & 32,2 & 32,5 & $-0,5$ & 0,3 \\
\hline M. R.F. & 27,8 & 28,4 & 28,7 & 0,6 & 0,3 \\
\hline M. P. & 23,5 & 28,7 & 29,4 & 5,2 & 0,7 \\
\hline M. S. G. & 31,4 & 33,5 & 33,9 & 2,1 & 0,4 \\
\hline M. A. & 36,4 & 37,2 & 33,2 & 0,8 & -4 \\
\hline M. C. & 34,6 & 38,3 & 39,9 & 3,7 & 1,6 \\
\hline M. A. & 28,9 & 28,9 & 29,6 & 0 & 0,7 \\
\hline M. C. & 27,5 & 28,4 & 25,5 & 0,9 & $-2,9$ \\
\hline M. A. G. & 32,3 & 32,5 & 31 & 0,2 & $-1,5$ \\
\hline N. M. & 31,1 & 32,5 & 31,8 & 1,4 & $-0,7$ \\
\hline R. M. & 37,2 & 35,4 & 35,9 & $-1,8$ & 0,5 \\
\hline R. J.L.G. & 33,3 & 34,1 & 33,9 & 0,8 & $-0,2$ \\
\hline R. W. & 32,3 & 32,9 & 30,2 & 0,6 & $-2,7$ \\
\hline S. M. & 26,8 & 31,6 & 29,2 & 4,8 & $-2,4$ \\
\hline S. F.C. & 36 & 37,3 & 35,7 & 1,3 & $-1,6$ \\
\hline T. G. S. & 38,4 & 38,6 & 34,4 & 0,2 & $-4,2$ \\
\hline V. G. & 32,7 & 37,2 & 35 & 4,5 & $-2,2$ \\
\hline
\end{tabular}




\section{6- Medida SN.PP}

\begin{tabular}{|c|c|c|c|c|c|}
\hline Pacientes & SN.PP t1 & SN.PP t2 & SN.PP t3 & SN.PP 2-1 & SN.PP 3-2 \\
\hline A.F.S. & 10,4 & 11,1 & 14,1 & 0,7 & 3 \\
\hline A.S. & 7,6 & 11,4 & 12 & 3,8 & 0,6 \\
\hline A.A. M. & 4,4 & 4,4 & 6 & 0 & 1,6 \\
\hline A. R. Jr. & 7,6 & 6,5 & 8,1 & $-1,1$ & 1,6 \\
\hline A.A. Jr. & 2,7 & 2,6 & $-1,6$ & $-0,1$ & $-4,2$ \\
\hline C. C. 0. & 6,4 & 5,5 & 5,8 & $-0,9$ & 0,3 \\
\hline C. M.R. & 17,1 & 15,1 & 14 & -2 & $-1,1$ \\
\hline D. S. M. & 5,9 & 4,5 & 3,8 & $-1,4$ & $-0,7$ \\
\hline E.D.P.F. P. & 8,4 & 7,1 & 7,7 & $-1,3$ & 0,6 \\
\hline F. C. & 9,1 & 11,5 & 11,3 & 2,4 & $-0,2$ \\
\hline J. R. T. & 8,5 & 8,3 & 9,5 & $-0,2$ & 1,2 \\
\hline J. C.A.O. & 6,8 & 5,1 & 5,2 & $-1,7$ & 0,1 \\
\hline K.C. & 5 & 2,9 & 6,7 & $-2,1$ & 3,8 \\
\hline L. F. & 7,9 & 7,8 & 7,1 & $-0,1$ & $-0,7$ \\
\hline M. S. R. & 5,8 & 8,2 & 6,5 & 2,4 & $-1,7$ \\
\hline M. R.F. & 8,3 & 8,3 & 7,4 & 0 & $-0,9$ \\
\hline M. P. & 7,8 & 9,2 & 9,8 & 1,4 & 0,6 \\
\hline M. S. G. & 9 & 9,1 & 10,4 & 0,1 & 1,3 \\
\hline M. A. & 5,7 & 11,3 & 12,1 & 5,6 & 0,8 \\
\hline M. C. & 11,2 & 13,3 & 12,6 & 2,1 & $-0,7$ \\
\hline M. A. & 16 & 7,8 & 7,3 & $-8,2$ & $-0,5$ \\
\hline M. C. & 4,8 & 8,4 & 8,4 & 3,6 & 0 \\
\hline M. A. G. & 6 & 9,2 & 9,3 & 3,2 & 0,1 \\
\hline N. M. & 2,2 & 2,8 & 2 & 0,6 & $-0,8$ \\
\hline R. M. & 9,5 & 9,7 & 10,5 & 0,2 & 0,8 \\
\hline R. J.L.G. & 5,1 & 4,9 & 5,4 & $-0,2$ & 0,5 \\
\hline R. W. & 7,9 & 9,3 & 8,6 & 1,4 & $-0,7$ \\
\hline S. M. & 10,9 & 9,3 & 8,7 & $-1,6$ & $-0,6$ \\
\hline S. F. C. & 11,2 & 11 & 11,4 & $-0,2$ & 0,4 \\
\hline T. G. S. & 5,4 & 6,6 & 6,3 & 1,2 & $-0,3$ \\
\hline V. G. & 4,7 & 5,1 & 4,7 & 0,4 & $-0,4$ \\
\hline
\end{tabular}




\section{7- Medida Ar.GoMe}

\begin{tabular}{|c|c|c|c|c|c|}
\hline Pacientes & Ar.GoMe t1 & Ar.GoMe t2 & Ar.GoMe t3 & Ar.GoMe t2-t1 & Go.ang t3-t2 \\
\hline A.F.S. & 138,6 & 140 & 127,2 & 1,4 & $-12,8$ \\
\hline A.S. & 125,8 & 127,1 & 126,2 & 1,3 & $-0,9$ \\
\hline A.A. M. & 129,5 & 126,9 & 121,9 & $-2,6$ & -5 \\
\hline A. R. Jr. & 125,4 & 123,7 & 115 & $-1,7$ & $-8,7$ \\
\hline A.A. Jr. & 130,6 & 133,9 & 133,3 & 3,3 & $-0,6$ \\
\hline C. C. 0 . & 131,8 & 130,8 & 129,2 & -1 & $-1,6$ \\
\hline C. M.R. & 125,9 & 126,7 & 127,2 & 0,8 & 0,5 \\
\hline D. S. M. & 132,6 & 132,6 & 134,1 & 0 & 1,5 \\
\hline E.D.P.F. P. & 129,8 & 127 & 126,7 & $-2,8$ & $-0,3$ \\
\hline F.C. & 137,9 & 136,5 & 131,2 & $-1,4$ & $-5,3$ \\
\hline J. R. T. & 123,4 & 125,4 & 122,5 & 2 & $-2,9$ \\
\hline J.C.A.O. & 127,4 & 127,3 & 123,8 & $-0,1$ & $-3,5$ \\
\hline K.C. & 122,8 & 119,7 & 118,2 & $-3,1$ & $-1,5$ \\
\hline L. F. & 129,5 & 129,9 & 128,9 & 0,4 & -1 \\
\hline M. S. R. & 122,7 & 122,8 & 122,2 & 0,1 & $-0,6$ \\
\hline M. R.F. & 122,6 & 121,8 & 121,5 & $-0,8$ & $-0,3$ \\
\hline M. P. & 131,1 & 139,9 & 136,7 & 8,8 & $-3,2$ \\
\hline M. S. G. & 132,8 & 132,4 & 133 & $-0,4$ & 0,6 \\
\hline M. A. & 138,2 & 138,7 & 135,2 & 0,5 & $-3,5$ \\
\hline M. C. & 132,4 & 132,5 & 131,9 & 0,1 & $-0,6$ \\
\hline M. A. & 131,7 & 122,6 & 127,9 & $-9,1$ & 5,3 \\
\hline M. C. & 128,6 & 128 & 126,9 & $-0,6$ & $-1,1$ \\
\hline M. A. G. & 126,2 & 127,4 & 124,9 & 1,2 & $-2,5$ \\
\hline N. M. & 135,4 & 137 & 137,9 & 1,6 & 0,9 \\
\hline R. M. & 134,3 & 135,8 & 134,7 & 1,5 & $-1,1$ \\
\hline R. J.L.G. & 132,1 & 131,3 & 132,3 & $-0,8$ & 1 \\
\hline R. W. & 129 & 130,8 & 126,6 & 1,8 & $-4,2$ \\
\hline S. M. & 131,6 & 135,8 & 134,3 & 4,2 & $-1,5$ \\
\hline S. F. C. & 129,8 & 130,9 & 127,8 & 1,1 & $-3,1$ \\
\hline T. G. S. & 134,6 & 129,3 & 126 & $-5,3$ & $-3,3$ \\
\hline V. G. & 127,9 & 126,4 & 127,8 & $-1,5$ & 1,4 \\
\hline
\end{tabular}


8- Medida SN.PO

\begin{tabular}{|c|c|c|c|c|c|}
\hline Pacientes & $\mathrm{SN}-\mathrm{PO} \mathrm{t} 1$ & SN-PO t2 & $\mathrm{SN}-\mathrm{PO} \mathrm{t} 3$ & SN-PO2-1 & SN-PO3-2 \\
\hline A.F.S. & 25,7 & 21,4 & 14 & $-4,3$ & $-7,4$ \\
\hline A.S. & 16,4 & 15,3 & 15,4 & $-1,1$ & 0,1 \\
\hline A.A. M. & 21,2 & 15 & 11,2 & $-6,2$ & $-3,8$ \\
\hline A. R. Jr. & 21,3 & 18,4 & 12,9 & $-2,9$ & $-5,5$ \\
\hline A.A. Jr. & 15,4 & 14,5 & 11,9 & $-0,9$ & $-2,6$ \\
\hline C. C. 0. & 27,6 & 17,3 & 15,5 & $-10,3$ & $\begin{array}{l}-1,8 \\
\end{array}$ \\
\hline C. M.R. & 19,4 & 12,8 & 13,3 & $-6,6$ & 0,5 \\
\hline D. S. M. & 19,3 & 13,6 & 14,8 & $-5,7$ & 1,2 \\
\hline E.D.P.F. P. & 15,8 & 12,2 & 11,9 & $-3,6$ & $-0,3$ \\
\hline F. C. & 31,5 & 25,3 & 24,3 & $-6,2$ & -1 \\
\hline J. R. T. & 15 & 17,9 & 15 & 2,9 & $-2,9$ \\
\hline J. C.A.O. & 13,5 & 7,5 & 7,3 & -6 & $-0,2$ \\
\hline K.C. & 14,5 & 12,6 & 13,2 & $-1,9$ & 0,6 \\
\hline L. F. & 26,7 & 19,4 & 20,9 & $-7,3$ & 1,5 \\
\hline M. S. R. & 23,4 & 19,3 & 18,6 & $-4,1$ & $-0,7$ \\
\hline M. R.F. & 17,9 & 18,8 & 16,2 & 0,9 & $-2,6$ \\
\hline M. P. & 20,2 & 16,3 & 19,5 & $-3,9$ & 3,2 \\
\hline M. S. G. & 26,5 & 23,3 & 22,3 & $-3,2$ & -1 \\
\hline M. A. & 18,4 & 18,3 & 17,9 & $-0,1$ & $-0,4$ \\
\hline M. C. & 24,5 & 20,6 & 22,9 & $-3,9$ & 2,3 \\
\hline M. A. & 20,6 & 14,2 & 13,9 & $-6,4$ & $-0,3$ \\
\hline M. C. & 18,6 & 18,2 & 18,3 & $-0,4$ & 0,1 \\
\hline M. A. G. & 20,8 & 19,5 & 18,3 & $-1,3$ & $-1,2$ \\
\hline N. M. & 16,9 & 16,9 & 16,9 & 0 & 0 \\
\hline R. M. & 24,7 & 14,5 & 17,8 & $-10,2$ & 3,3 \\
\hline R. J.L.G. & 20,8 & 15,6 & 17,6 & $-5,2$ & 2 \\
\hline R. W. & 18,7 & 15,4 & 15,1 & $-3,3$ & $-0,3$ \\
\hline S. M. & 18,4 & 12,2 & 14,3 & $-6,2$ & 2,1 \\
\hline S. F. C. & 25,7 & 22,8 & 28,2 & $-2,9$ & 5,4 \\
\hline T. G. S. & 24,9 & 23,7 & 18,1 & $-1,2$ & $-5,6$ \\
\hline V. G. & 15,3 & 16,1 & 12,4 & 0,8 & $-3,7$ \\
\hline
\end{tabular}




\section{9-Medida Ar-Go}

\begin{tabular}{|c|c|c|c|c|c|}
\hline Pacientes & Ar-Go T1 & Ar-Go T2 & Ar-Go T3 & Ar-Go 2-1 & Ar-Go 3-2 \\
\hline A.F.S. & 41,2 & 42,3 & 44,8 & 1,1 & 2,5 \\
\hline A.S. & 44,9 & 46,6 & 45,6 & 1,7 & -1 \\
\hline A.A. M. & 37 & 34,6 & 42,8 & $-2,4$ & 8,2 \\
\hline A. R. Jr. & 41,3 & 39,6 & 51,1 & $-1,7$ & 11,5 \\
\hline A.A. Jr. & 49,8 & 52,7 & 51,9 & 2,9 & $-0,8$ \\
\hline C. C. 0. & 36,1 & 38,4 & 41,5 & 2,3 & 3,1 \\
\hline C. M.R. & 43,1 & 43,6 & 45 & 0,5 & 1,4 \\
\hline D. S. M. & 39 & 43,7 & 46,8 & 4,7 & 3,1 \\
\hline E.D.P.F. P. & 41,8 & 43 & 46,1 & 1,2 & 3,1 \\
\hline F.C. & 34,5 & 35,3 & 39,4 & 0,8 & 4,1 \\
\hline J. R. T. & 41,6 & 39,7 & 45,2 & $-1,9$ & 5,5 \\
\hline J. C.A.O. & 44,6 & 44,7 & 44,6 & 0,1 & $-0,1$ \\
\hline K.C. & 35,3 & 38,6 & 40,5 & 3,3 & 1,9 \\
\hline L. F. & 42,3 & 42,6 & 41 & 0,3 & $-1,6$ \\
\hline M. S. R. & 41,2 & 46,2 & 45,7 & 5 & $-0,5$ \\
\hline M. R.F. & 42,5 & 46,4 & 46 & 3,9 & $-0,4$ \\
\hline M. P. & 44,7 & 46,8 & 43,5 & 2,1 & $-3,3$ \\
\hline M. S. G. & 33,1 & 35,4 & 36,5 & 2,3 & 1,1 \\
\hline M. A. & 37,4 & 35,7 & 42 & $-1,7$ & 6,3 \\
\hline M. C. & 40,8 & 40,6 & 39,3 & $-0,2$ & $-1,3$ \\
\hline M. A. & 39 & 43,9 & 45,2 & 4,9 & 1,3 \\
\hline M. C. & 37,2 & 39,3 & 44,9 & 2,1 & 5,6 \\
\hline M. A. G. & 43,8 & 44,1 & 45,6 & 0,3 & 1,5 \\
\hline N. M. & 43,4 & 45,2 & 42,9 & 1,8 & $-2,3$ \\
\hline R. M. & 42 & 41,5 & 40,4 & $-0,5$ & $-1,1$ \\
\hline R. J.L.G. & 37,4 & 40,7 & 45,5 & 3,3 & 4,8 \\
\hline R. W. & 40,2 & 44 & 44,2 & 3,8 & 0,2 \\
\hline S. M. & 43,9 & 44,3 & 42,4 & 0,4 & $-1,9$ \\
\hline S. F. C. & 35,2 & 33,8 & 36,9 & $-1,4$ & 3,1 \\
\hline T. G. S. & 34 & 35,8 & 40,7 & 1,8 & 4,9 \\
\hline V. G. & 44,4 & 39,8 & 46,6 & $-4,6$ & 6,8 \\
\hline
\end{tabular}


10-Medida S-Go

\begin{tabular}{|c|c|c|c|c|c|}
\hline Pacientes & S-Go T1 & S-Go T2 & S-Go T3 & S-Go 2-1 & S-Go 3-2 \\
\hline A.F.S. & 66,8 & 69,1 & 73,8 & 2,3 & 4,7 \\
\hline A.S. & 70,4 & 71,2 & 72,6 & 0,8 & 1,4 \\
\hline A.A. M. & 66,9 & 67,6 & 76,5 & 0,7 & 8,9 \\
\hline A. R. Jr. & 66,8 & 69,4 & 80,9 & 2,6 & 11,5 \\
\hline A.A. Jr. & 77,7 & 81,5 & 82,2 & 3,8 & 0,7 \\
\hline C. C. 0. & 62,1 & 64,9 & 68,7 & 2,8 & 3,8 \\
\hline C. M.R. & 72,2 & 73,1 & 74,1 & 0,9 & 1 \\
\hline D. S. M. & 72,4 & 77,2 & 79,2 & 4,8 & 2 \\
\hline E.D.P.F. P. & 67,7 & 69,6 & 70,2 & 1,9 & 0,6 \\
\hline F.C. & 64,7 & 62,9 & 65,8 & $-1,8$ & 2,9 \\
\hline J. R. T. & 72,1 & 75 & 76,9 & 2,9 & 1,9 \\
\hline J. C.A.O. & 73,9 & 75,4 & 74,8 & 1,5 & $-0,6$ \\
\hline K.C. & 58,5 & 62,5 & 62,7 & 4 & 0,2 \\
\hline L. F. & 71,2 & 74,8 & 71,5 & 3,6 & $-3,3$ \\
\hline M. S. R. & 73,1 & 79,1 & 78,6 & 6 & $-0,5$ \\
\hline M. R.F. & 77,6 & 80 & 78,9 & 2,4 & $-1,1$ \\
\hline M. P. & 68,5 & 68,6 & 64,1 & 0,1 & $-4,5$ \\
\hline M. S. G. & 62,6 & 65,6 & 65,7 & 3 & 0,1 \\
\hline M. A. & 62,1 & 63,9 & 66,5 & 1,8 & 2,6 \\
\hline M. C. & 65,5 & 64,5 & 63,5 & -1 & -1 \\
\hline M. A. & 69,6 & 74,3 & 77,3 & 4,7 & 3 \\
\hline M. C. & 59 & 62,1 & 68,8 & 3,1 & 6,7 \\
\hline M. A. G. & 72 & 71,9 & 73,4 & $-0,1$ & 1,5 \\
\hline N. M. & 68,4 & 70,9 & 70,2 & 2,5 & $-0,7$ \\
\hline R. M. & 73,7 & 74,3 & 73,4 & 0,6 & $-0,9$ \\
\hline R. J.L.G. & 65,7 & 70,6 & 74,9 & 4,9 & 4,3 \\
\hline R. W. & 65,8 & 70,5 & 71,5 & 4,7 & 1 \\
\hline S. M. & 67,9 & 70,2 & 71,7 & 2,3 & 1,5 \\
\hline S. F.C. & 66,3 & 64,2 & 67,8 & $-2,1$ & 3,6 \\
\hline T. G. S. & 61,6 & 66,3 & 73,1 & 4,7 & 6,8 \\
\hline V. G. & 72,6 & 72,5 & 75,3 & $-0,1$ & 2,8 \\
\hline
\end{tabular}


11- Medida 1S.PP

\begin{tabular}{|c|c|c|c|c|c|}
\hline Pacientes & 1S.PP t1 & 1S.PP t2 & 1S.PP t3 & 1S.PP2-1 & 1S.PP3-2 \\
\hline A.F.S. & 115,5 & 102,6 & 116,6 & $-12,9$ & 14 \\
\hline A.S. & 121,8 & 113,5 & 114,7 & $-8,3$ & 1,2 \\
\hline A.A. M. & 123,6 & 116,6 & 115,5 & -7 & $-1,1$ \\
\hline A. R. Jr. & 118,4 & 107,8 & 112,6 & $-10,6$ & 4,8 \\
\hline A.A. Jr. & 115,5 & 106,7 & 114,1 & $-8,8$ & 7,4 \\
\hline C. C. 0. & 119,8 & 108,6 & 118,4 & $-11,2$ & 9,8 \\
\hline C. M.R. & 133 & 118,9 & 117,8 & $-14,1$ & $-1,1$ \\
\hline D. S. M. & 118,8 & 109,9 & 113,3 & $-8,9$ & 3,4 \\
\hline E.D.P.F. P. & 125,2 & 116,2 & 116,1 & -9 & $-0,1$ \\
\hline F.C. & 118,6 & 109,9 & 114,5 & $-8,7$ & 4,6 \\
\hline J. R. T. & 128,1 & 110,2 & 105,4 & $-17,9$ & $-4,8$ \\
\hline J. C.A.O. & 123,6 & 124,3 & 124,7 & 0,7 & 0,4 \\
\hline K.C. & 124,8 & 130,2 & 128,3 & 5,4 & $-1,9$ \\
\hline L. F. & 104,3 & 103,3 & 96,8 & -1 & $-6,5$ \\
\hline M. S. R. & 117,6 & 107,5 & 105,7 & $-10,1$ & $-1,8$ \\
\hline M. R.F. & 114,6 & 113,7 & 113,7 & $-0,9$ & 0 \\
\hline M. P. & 110,8 & 113,3 & 98,7 & 2,5 & $-14,6$ \\
\hline M. S. G. & 114 & 112,5 & 110,4 & $-1,5$ & $-2,1$ \\
\hline M. A. & 112,6 & 114,1 & 110,5 & 1,5 & $-3,6$ \\
\hline M. C. & 112,4 & 103,1 & 105,5 & $-9,3$ & 2,4 \\
\hline M. A. & 126,6 & 113,7 & 118,2 & $-12,9$ & 4,5 \\
\hline M. C. & 113,5 & 107,8 & 108 & $-5,7$ & 0,2 \\
\hline M. A. G. & 108,4 & 113,3 & 107,2 & 4,9 & $-6,1$ \\
\hline N. M. & 118,9 & 103,3 & 108,3 & $-15,6$ & 5 \\
\hline R. M. & 116,4 & 114,6 & 114,4 & $-1,8$ & $-0,2$ \\
\hline R. J.L.G. & 104,5 & 61,2 & 105,5 & $-43,3$ & 44,3 \\
\hline R. W. & 126,8 & 112,3 & 117,4 & $-14,5$ & 5,1 \\
\hline S. M. & 114,1 & 115,6 & 114,3 & 1,5 & $-1,3$ \\
\hline S. F. C. & 109,8 & 100,7 & 97,1 & $-9,1$ & $-3,6$ \\
\hline T. G. S. & 108,4 & 102,4 & 110,4 & -6 & 8 \\
\hline V. $\mathbf{G}$. & 119,5 & 101,5 & 98,8 & -18 & $-2,7$ \\
\hline
\end{tabular}


12- Medida IMPA

\begin{tabular}{|c|c|c|c|c|c|}
\hline Pacientes & IMPA t1 & IMPA t2 & IMPA t3 & IMPA2-1 & IMPA3-2 \\
\hline A.F.S. & 77,7 & 75,7 & 94,1 & -2 & 18,4 \\
\hline A.S. & 93,3 & 88,3 & 88,9 & -5 & 0,6 \\
\hline A.A. M. & 91,7 & 90,6 & 93,8 & $-1,1$ & 3,2 \\
\hline A. R. Jr. & 97 & 93,1 & 93,2 & $-3,9$ & 0,1 \\
\hline A.A. Jr. & 92,7 & 81,9 & 82,3 & $-10,8$ & 0,4 \\
\hline C. C. 0. & 91,3 & 77,6 & 81,2 & $-13,7$ & 3,6 \\
\hline C. M.R. & 94,1 & 88,6 & 94,7 & $-5,5$ & 6,1 \\
\hline D. S. M. & 86,4 & 81,2 & 85 & $-5,2$ & 3,8 \\
\hline E.D.P.F. P. & 97,5 & 92,2 & 92,5 & $-5,3$ & 0,3 \\
\hline F.C. & 100,2 & 92,4 & 96,9 & $-7,8$ & 4,5 \\
\hline J. R. T. & 87,7 & 83,2 & 86,1 & $-4,5$ & 2,9 \\
\hline J. C.A.O. & 89,2 & 88 & 88,6 & $-1,2$ & 0,6 \\
\hline K.C. & 87,3 & 86,8 & 97,3 & $-0,5$ & 10,5 \\
\hline L. $\mathbf{F}$. & 89,6 & 83,4 & 84 & $-6,2$ & 0,6 \\
\hline M. S. R. & 93,5 & 90,9 & 91,4 & $-2,6$ & 0,5 \\
\hline M. R.F. & 95,5 & 95,7 & 93,5 & 0,2 & $-2,2$ \\
\hline M. P. & 91,5 & 83,4 & 85 & $-8,1$ & 1,6 \\
\hline M. S. G. & 86,4 & 78,6 & 81,5 & $-7,8$ & 2,9 \\
\hline M. A. & 81,2 & 79,3 & 83,9 & $-1,9$ & 4,6 \\
\hline M. C. & 88 & 79,8 & 88,3 & $-8,2$ & 8,5 \\
\hline M. A. & 102,4 & 92,5 & 94,4 & $-9,9$ & 1,9 \\
\hline M. C. & 98,6 & 87,2 & 88 & $-11,4$ & 0,8 \\
\hline M. A. G. & 100,9 & 93,1 & 90,3 & $-7,8$ & $-2,8$ \\
\hline N. M. & 94,9 & 89,4 & 90,6 & $-5,5$ & 1,2 \\
\hline R. M. & 84 & 74,2 & 80,2 & $-9,8$ & 6 \\
\hline R. J.L.G. & 84,5 & 75,5 & 77,7 & -9 & 2,2 \\
\hline R. W. & 93,7 & 84,8 & 90,5 & $-8,9$ & 5,7 \\
\hline S. M. & 85,9 & 80,3 & 80,2 & $-5,6$ & $-0,1$ \\
\hline S. F. C. & 82,2 & 75,6 & 81,6 & $-6,6$ & 6 \\
\hline T. G. S. & 86,1 & 88,4 & 87,1 & 2,3 & $-1,3$ \\
\hline V. G. & 85,1 & 89,7 & 85,2 & 4,6 & $-4,5$ \\
\hline
\end{tabular}


13 Medida BiS-NA

\begin{tabular}{|c|c|c|c|c|c|}
\hline Pacientes & 1S-NA t1 & 1S-NA t2 & 1S-NA t3 & |1S-NA2-1 & 1S-NA3-2 \\
\hline A.F.S. & 6,9 & 2,4 & 6,9 & $-4,5$ & 4,5 \\
\hline A.S. & 7,3 & 3 & 3,3 & $-4,3$ & 0,3 \\
\hline A.A. M. & 6,2 & 4,4 & 6,3 & $-1,8$ & 1,9 \\
\hline A. R. Jr. & 6,5 & 3,3 & 5,4 & $-3,2$ & 2,1 \\
\hline A.A. Jr. & 7,8 & 3,6 & 7,5 & $-4,2$ & 3,9 \\
\hline C. C. 0. & 10,6 & 3,8 & 7 & $-6,8$ & 3,2 \\
\hline C. M.R. & 10,8 & 7,3 & 7,1 & $-3,5$ & $-0,2$ \\
\hline D. S. M. & 10,2 & 5,3 & 7,4 & $-4,9$ & 2,1 \\
\hline E.D.P.F. P. & 10,1 & 6,3 & 6,9 & $-3,8$ & 0,6 \\
\hline F. C. & 7,7 & 0,8 & 3,5 & $-6,9$ & 2,7 \\
\hline J.R. T. & 10,6 & 1,6 & 1,7 & -9 & 0,1 \\
\hline J. C.A.O. & 6 & 7,5 & 5,6 & 1,5 & $-1,9$ \\
\hline K.C. & 7,4 & 11,6 & 10,3 & 4,2 & $-1,3$ \\
\hline L. F. & 5,8 & 4 & 1,8 & $-1,8$ & $-2,2$ \\
\hline M. S. R. & 12 & 2,7 & 4,9 & $-9,3$ & 2,2 \\
\hline M. R.F. & 7,6 & 5,3 & 3,8 & $-2,3$ & $-1,5$ \\
\hline M. P. & 3,2 & 1,7 & $-1,2$ & $-1,5$ & $-2,9$ \\
\hline M. S. G. & 7,8 & 8,6 & 6,9 & 0,8 & $-1,7$ \\
\hline M. A. & 4,9 & 4,7 & 7,2 & $-0,2$ & 2,5 \\
\hline M. C. & 3,3 & 0,6 & 7 & $-2,7$ & 6,4 \\
\hline M. A. & 13,9 & 6,5 & 5,5 & $-7,4$ & -1 \\
\hline M. C. & 6,6 & 6 & 6,5 & $-0,6$ & 0,5 \\
\hline M. A. G. & 4,9 & 4,6 & $-1,8$ & $-0,3$ & $-6,4$ \\
\hline N. M. & 9,5 & 2 & 5,5 & $-7,5$ & 3,5 \\
\hline R. M. & 6,8 & 3,1 & 5,2 & $-3,7$ & 2,1 \\
\hline R. J.L.G. & 4,7 & $-4,1$ & 5,9 & $-8,8$ & 10 \\
\hline R. W. & 8,2 & 3 & 6,5 & $-5,2$ & 3,5 \\
\hline S. M. & 6 & 7,4 & 6,9 & 1,4 & $-0,5$ \\
\hline S. F.C. & 6,9 & 2,6 & 4 & $-4,3$ & 1,4 \\
\hline T. G. S. & 6,6 & 4,8 & 6,8 & $-1,8$ & 2 \\
\hline V. G. & 7,9 & 1,1 & 1,5 & $-6,8$ & 0,4 \\
\hline
\end{tabular}




\section{4-Medida BII-NB}

\begin{tabular}{|c|c|c|c|c|c|}
\hline Pacientes & Bll-NB t1 & Bll-NB t2 & Bll-NB t3 & Bll-NB 2-1 & BII-NB 3-2 \\
\hline A.F.S. & 3,5 & 3,6 & 6,5 & 0,1 & 2,9 \\
\hline A.S. & 7,9 & 4,8 & 5,7 & $-3,1$ & 0,9 \\
\hline A.A. M. & 6,6 & 6,2 & 6,3 & $-0,4$ & 0,1 \\
\hline A. R. Jr. & 8,2 & 7,7 & 7,4 & $-0,5$ & $-0,3$ \\
\hline A.A. Jr. & 7,3 & 5,9 & 6,7 & $-1,4$ & 0,8 \\
\hline C. C. 0. & 7,7 & 6,4 & 6,9 & $-1,3$ & 0,5 \\
\hline C. M.R. & 5,9 & 6,1 & 6,7 & 0,2 & 0,6 \\
\hline D. S. M. & 5,2 & 5,5 & 5,5 & 0,3 & 0 \\
\hline E.D.P.F. P. & 9 & 6,4 & 7 & $-2,6$ & 0,6 \\
\hline F.C. & 7,8 & 7 & 7,7 & $-0,8$ & 0,7 \\
\hline J.R. T. & 7,4 & 5,6 & 5,7 & $-1,8$ & 0,1 \\
\hline J. C.A.O. & 5,5 & 5 & 5,8 & $-0,5$ & 0,8 \\
\hline K.C. & 6,6 & 5,9 & 7,6 & $-0,7$ & 1,7 \\
\hline L. F. & 6,7 & 5,1 & 5,5 & $-1,6$ & 0,4 \\
\hline M. S. R. & 5,3 & 6,4 & 6,3 & 1,1 & $-0,1$ \\
\hline M. R.F. & 7,7 & 9,2 & 9,4 & 1,5 & 0,2 \\
\hline M. P. & 3 & 3,6 & 3,5 & 0,6 & $-0,1$ \\
\hline M. S. G. & 4,4 & 3,7 & 3,9 & $-0,7$ & 0,2 \\
\hline M. A. & 5,4 & 6,7 & 6,1 & 1,3 & $-0,6$ \\
\hline M. C. & 7,4 & 5,3 & 8,1 & $-2,1$ & 2,8 \\
\hline M. A. & 7,1 & 7,4 & 8,3 & 0,3 & 0,9 \\
\hline M. C. & 6 & 3,3 & 4 & $-2,7$ & 0,7 \\
\hline M. A. G. & 9,1 & 5,3 & 5 & $-3,8$ & $-0,3$ \\
\hline N. M. & 6,8 & 6,2 & 6,5 & $-0,6$ & 0,3 \\
\hline R. M. & 5,4 & 3,3 & 3,9 & $-2,1$ & 0,6 \\
\hline R. J.L.G. & 6,6 & 5,5 & 7,1 & $-1,1$ & 1,6 \\
\hline R. W. & 8,8 & 7,3 & 9,2 & $-1,5$ & 1,9 \\
\hline S. M. & 3 & 4,5 & 3,6 & 1,5 & $-0,9$ \\
\hline S. F. C. & 6,7 & 5,1 & 6,2 & $-1,6$ & 1,1 \\
\hline T. G. S. & 7,1 & 5,8 & 6 & $-1,3$ & 0,2 \\
\hline V. G. & 7,2 & 5,7 & 4,6 & $-1,5$ & $-1,1$ \\
\hline
\end{tabular}


15-Medida 1S.NA

\begin{tabular}{|c|c|c|c|c|c|}
\hline Pacientes & 1S.NA t1 & 1S.NA t2 & 1S.NA t3 & 1S.NA2-1 & 1S.NA3-2 \\
\hline A.F.S. & 27,8 & 12,1 & 24,2 & $-15,7$ & 12,1 \\
\hline A.S. & 28,9 & 18,2 & 20,4 & $-10,7$ & 2,2 \\
\hline A.A. M. & 33 & 28 & 27,2 & -5 & $-0,8$ \\
\hline A. R. Jr. & 28,7 & 19 & 24 & $-9,7$ & 5 \\
\hline A.A. Jr. & 31,5 & 23,5 & 34,6 & -8 & 11,1 \\
\hline C. C. 0. & 37,2 & 25,8 & 34,3 & $-11,4$ & 8,5 \\
\hline C. M.R. & 38,6 & 25,8 & 25,2 & $-12,8$ & $-0,6$ \\
\hline D. S. M. & 33,9 & 24,6 & 30,8 & $-9,3$ & 6,2 \\
\hline E.D.P.F. P. & 33,4 & 25,2 & 25,3 & $-8,2$ & 0,1 \\
\hline F.C. & 29,9 & 15,8 & 21,8 & $-14,1$ & 6 \\
\hline J.R. T. & 38,4 & 19,7 & 15,4 & $-18,7$ & $-4,3$ \\
\hline J. C.A.O. & 29,5 & 32,8 & 31,8 & 3,3 & -1 \\
\hline K.C. & 29,4 & 43,8 & 38,4 & 14,4 & $-5,4$ \\
\hline L. F. & 19,5 & 19,5 & 11,7 & 0 & $-7,8$ \\
\hline M. S. R. & 35,4 & 22,2 & 23,9 & $-13,2$ & 1,7 \\
\hline M. R.F. & 26,1 & 25,1 & 23,9 & -1 & $-1,2$ \\
\hline M. P. & 22,1 & 23,4 & 23 & 1,3 & $-0,4$ \\
\hline M. S. G. & 30,3 & 29,7 & 26,7 & $-0,6$ & -3 \\
\hline M. A. & 25,3 & 25,3 & 24,2 & 0 & $-1,1$ \\
\hline M. C. & 21,4 & 13,2 & 19,7 & $-8,2$ & 6,5 \\
\hline M. A. & 34,4 & 26,4 & 29 & -8 & 2,6 \\
\hline M. C. & 31,1 & 25,2 & 25,2 & $-5,9$ & 0 \\
\hline M. A. G. & 19,6 & 25,1 & 14,3 & 5,5 & $-10,8$ \\
\hline N. M. & 36 & 18,2 & 25,4 & $-17,8$ & 7,2 \\
\hline R. M. & 27,4 & 24,9 & 25,4 & $-2,5$ & 0,5 \\
\hline R. J.L.G. & 17,7 & 25,2 & 19,3 & 7,5 & $-5,9$ \\
\hline R. W. & 36,8 & 21,8 & 27,9 & -15 & 6,1 \\
\hline S. M. & 27,2 & 30 & 28,5 & 2,8 & $-1,5$ \\
\hline S. F. C. & 23,9 & 14,1 & 12,2 & $-9,8$ & $-1,9$ \\
\hline T. G. S. & 30,4 & 21,8 & 30,8 & $-8,6$ & 9 \\
\hline V. G. & 31,5 & 15,1 & 12,5 & $-16,4$ & $-2,6$ \\
\hline
\end{tabular}


16-Medida 1I.NB

\begin{tabular}{|c|c|c|c|c|c|}
\hline Pacientes & 1I.NB t1 & 1I.NB t2 & 1I.NB t3 & 1I.NB2-1 & 1I.NB3-2 \\
\hline A.F.S. & 17 & 16,1 & 28 & $-0,9$ & 11,9 \\
\hline A.S. & 27,7 & 24,6 & 24,2 & $-3,1$ & $-0,4$ \\
\hline A.A. M. & 30,5 & 27,1 & 29,2 & $-3,4$ & 2,1 \\
\hline A. R. Jr. & 35,6 & 30 & 25,6 & $-5,6$ & $-4,4$ \\
\hline A.A. Jr. & 30,7 & 21 & 22,5 & $-9,7$ & 1,5 \\
\hline c. c. 0 . & 30,5 & 16,9 & 21,7 & $-13,6$ & 4,8 \\
\hline C. M.R. & 28,7 & 22,8 & 28,6 & $-5,9$ & 5,8 \\
\hline D. S. M. & 23,9 & 18,5 & 22,3 & $-5,4$ & 3,8 \\
\hline E.D.P.F. P. & 35 & 29,5 & 28,9 & $-5,5$ & $-0,6$ \\
\hline F. C. & 40,5 & 34,9 & 35,5 & $-5,6$ & 0,6 \\
\hline J.R. T. & 26,9 & 22,5 & 22,9 & $-4,4$ & 0,4 \\
\hline J. C.A.O. & 28,5 & 25,7 & 26,7 & $-2,8$ & 1 \\
\hline K.C. & 27,1 & 24,4 & 34 & $-2,7$ & 9,6 \\
\hline L. F. & 27,4 & 22 & 22,9 & $-5,4$ & 0,9 \\
\hline M. S. R. & 28,3 & 23,7 & 23,8 & $-4,6$ & 0,1 \\
\hline M. R.F. & 29,9 & 30 & 27,5 & 0,1 & $-2,5$ \\
\hline M. P. & 21,2 & 19,4 & 21,9 & $-1,8$ & 2,5 \\
\hline M. S. G. & 26,9 & 20,4 & 22,2 & $-6,5$ & 1,8 \\
\hline M. A. & 21,2 & 18,8 & 21,3 & $-2,4$ & 2,5 \\
\hline M. C. & 26 & 20,3 & 29,1 & $-5,7$ & 8,8 \\
\hline M. A. & 36,9 & 28 & 29,7 & $-8,9$ & 1,7 \\
\hline M. C. & 31,2 & 19,4 & 20,9 & $-11,8$ & 1,5 \\
\hline M. A. G. & 37,9 & 31,1 & 26,4 & $-6,8$ & $-4,7$ \\
\hline N. M. & 31 & 26,3 & 28,6 & $-4,7$ & 2,3 \\
\hline R. M. & 24,7 & 13,9 & 19,8 & $-10,8$ & 5,9 \\
\hline R. J.L.G. & 27,7 & 19,8 & 22,1 & $-7,9$ & 2,3 \\
\hline R. W. & 32,1 & 23,6 & 28,9 & $-8,5$ & 5,3 \\
\hline S. M. & 19,3 & 16,3 & 16,4 & -3 & 0,1 \\
\hline S. F. C. & 22,2 & 16,7 & 20,6 & $-5,5$ & 3,9 \\
\hline T. G. S. & 24,2 & 25,3 & 21,7 & 1,1 & $-3,6$ \\
\hline V. G. & 22,6 & 27,2 & 22,8 & 4,6 & $-4,4$ \\
\hline
\end{tabular}


17-Medida-6S-PP

\begin{tabular}{|c|c|c|c|c|c|}
\hline Pacientes & $6 \mathrm{~S}-\mathrm{PP} \mathrm{t} 1$ & 6S-PP t2 & $6 \mathrm{~S}-\mathrm{PP} \mathrm{t} 3$ & 6S-PP 2-1 & 6S-PP 3-2 \\
\hline A.F.S. & 22,7 & 24,3 & 25,2 & 1,6 & 0,9 \\
\hline A.S. & 24,6 & 25 & 25,5 & 0,4 & 0,5 \\
\hline A.A. M. & 21,6 & 23,5 & 28,5 & 1,9 & 5 \\
\hline A. R. Jr. & 20,7 & 22,5 & 26,6 & 1,8 & 4,1 \\
\hline A.A. Jr. & 28,7 & 31,1 & 28,8 & 2,4 & $-2,3$ \\
\hline C. C. 0 . & 23,8 & 24,5 & 27,6 & 0,7 & 3,1 \\
\hline C. M.R. & 26,8 & 26,3 & 25,2 & $-0,5$ & $-1,1$ \\
\hline D. S. M. & 25,2 & 26,5 & 26,6 & 1,3 & 0,1 \\
\hline E.D.P.F.P. & 25,9 & 28,3 & 27 & 2,4 & $-1,3$ \\
\hline F. C. & 19,7 & 21,6 & 21,8 & 1,9 & 0,2 \\
\hline J.R. T. & 28,4 & 28,5 & 29,9 & 0,1 & 1,4 \\
\hline J. C.A.O. & 25,8 & 25,5 & 24,9 & $-0,3$ & $-0,6$ \\
\hline K.C. & 22,3 & 22,2 & 22,2 & $-0,1$ & 0 \\
\hline L. F. & 26,6 & 32,9 & 29,9 & 6,3 & -3 \\
\hline M. S. R. & 20,7 & 26,6 & 28,7 & 5,9 & 2,1 \\
\hline M. R.F. & 26,9 & 27,6 & 28,6 & 0,7 & 1 \\
\hline M. P. & 23 & 24,5 & 24,3 & 1,5 & $-0,2$ \\
\hline M. S. G. & 23,8 & 26,6 & 29 & 2,8 & 2,4 \\
\hline M. A. & 22,5 & 23,7 & 25,8 & 1,2 & 2,1 \\
\hline M. C. & 21,1 & 22,7 & 24,1 & 1,6 & 1,4 \\
\hline M. A. & 20,7 & 28,4 & 28,7 & 7,7 & 0,3 \\
\hline M. C. & 20 & 20,5 & 24,6 & 0,5 & 4,1 \\
\hline M. A. G. & 24,9 & 25,6 & 23,1 & 0,7 & $-2,5$ \\
\hline N. M. & 22,9 & 24,2 & 25,3 & 1,3 & 1,1 \\
\hline R. M. & 24,4 & 25,4 & 25,1 & 1 & $-0,3$ \\
\hline R. J.L.G. & 24,2 & 26,6 & 28,7 & 2,4 & 2,1 \\
\hline R. W. & 23,7 & 26 & 26,8 & 2,3 & 0,8 \\
\hline S. M. & 25 & 27,4 & 26,9 & 2,4 & $-0,5$ \\
\hline S. F. C. & 27,7 & 26,4 & 26,2 & $-1,3$ & $-0,2$ \\
\hline T. G. S. & 22,5 & 24,8 & 27,8 & 2,3 & 3 \\
\hline V. G. & 25,3 & 27,7 & 27,4 & 2,4 & $-0,3$ \\
\hline
\end{tabular}




\section{8-Medida 6I-GoMe}

\begin{tabular}{|c|c|c|c|c|c|}
\hline Pacientes & 6I-GoMe t1 & 6I-GoMe t2 & 6I-GoMe t3 & 6I-GoMe2-1 & 6I-GoMe3-2 \\
\hline A.F.S. & 29 & 30,7 & 31,6 & 1,7 & 0,9 \\
\hline A.S. & 29,9 & 31,6 & 31,8 & 1,7 & 0,2 \\
\hline A.A. M. & 30 & 30,6 & 32,1 & 0,6 & 1,5 \\
\hline A. R. Jr. & 30 & 31,9 & 36,1 & 1,9 & 4,2 \\
\hline A.A. Jr. & 30,3 & 32,8 & 34,2 & 2,5 & 1,4 \\
\hline c. c. 0. & 28,4 & 30,1 & 31,2 & 1,7 & 1,1 \\
\hline C. M.R. & 27,6 & 30,1 & 31,6 & 2,5 & 1,5 \\
\hline D. S. M. & 31,3 & 33,7 & 34,6 & 2,4 & 0,9 \\
\hline E.D.P.F. P. & 29,7 & 29,2 & 30,8 & $-0,5$ & 1,6 \\
\hline F. C. & 29,1 & 30,7 & 32,2 & 1,6 & 1,5 \\
\hline J.R. T. & 33 & 35,9 & 35,5 & 2,9 & $-0,4$ \\
\hline J. C.A.O. & 29,6 & 31,4 & 31,3 & 1,8 & $-0,1$ \\
\hline K.C. & 25,4 & 27,9 & 28 & 2,5 & 0,1 \\
\hline L. F. & 32,3 & 34 & 33,4 & 1,7 & $-0,6$ \\
\hline M. S. R. & 27,7 & 32,2 & 31,8 & 4,5 & $-0,4$ \\
\hline M. R.F. & 33,6 & 35,1 & 34,6 & 1,5 & $-0,5$ \\
\hline M. P. & 28,9 & 28,7 & 29,2 & $-0,2$ & 0,5 \\
\hline M. S. G. & 28,1 & 30,3 & 30,4 & 2,2 & 0,1 \\
\hline M. A. & 29,3 & 31,6 & 33,1 & 2,3 & 1,5 \\
\hline M. C. & 29,1 & 28,8 & 30,1 & $-0,3$ & 1,3 \\
\hline M. A. & 28 & 31,7 & 32,2 & 3,7 & 0,5 \\
\hline M. C. & 26,7 & 30,4 & 32,4 & 3,7 & 2 \\
\hline M. A. G. & 33,5 & 33,4 & 35 & $-0,1$ & 1,6 \\
\hline N. M. & 29,5 & 32,4 & 31,6 & 2,9 & $-0,8$ \\
\hline R. M. & 33,1 & 32,4 & 33 & $-0,7$ & 0,6 \\
\hline R. J.L.G. & 27,1 & 30,8 & 33,9 & 3,7 & 3,1 \\
\hline R.W. & 28,5 & 31 & 32,8 & 2,5 & 1,8 \\
\hline S. M. & 27,1 & 29,5 & 30 & 2,4 & 0,5 \\
\hline S. F.C. & 29,9 & 30,1 & 32,6 & 0,2 & 2,5 \\
\hline T. G. S. & 29,9 & 33,4 & 34,5 & 3,5 & 1,1 \\
\hline V. G. & 32,1 & 31,9 & 33 & $-0,2$ & 1,1 \\
\hline
\end{tabular}


19-Medida 1S-PP

\begin{tabular}{|c|c|c|c|c|c|}
\hline Pacientes & $1 S-P P t 1$ & 1S-PP t2 & 1S-PP t3 & 1S-PP 2-1 & 1S-PP 3-2 \\
\hline A.F.S. & 27,2 & 29,3 & 27,3 & 2,1 & -2 \\
\hline A.S. & 27,1 & 27,8 & 26,6 & 0,7 & $-1,2$ \\
\hline A.A. M. & 26,7 & 28,5 & 30,1 & 1,8 & 1,6 \\
\hline A. R. Jr. & 25,4 & 27,2 & 30,4 & 1,8 & 3,2 \\
\hline A.A. Jr. & 33,2 & 36,4 & 34,4 & 3,2 & -2 \\
\hline C. C. 0 . & 28,2 & 30,6 & 29,9 & 2,4 & $-0,7$ \\
\hline C. M.R. & 22,5 & 27,4 & 27,3 & 4,9 & $-0,1$ \\
\hline D. S. M. & 27,9 & 30,1 & 30,1 & 2,2 & 0 \\
\hline E.D.P.F. P. & 27,7 & 29,7 & 28,7 & 2 & -1 \\
\hline F.C. & 24,7 & 25,7 & 25,5 & 1 & $-0,2$ \\
\hline J. R. T. & 29,8 & 34,9 & 34,6 & 5,1 & $-0,3$ \\
\hline J. C.A.O. & 25,5 & 27,5 & 27,4 & 2 & $-0,1$ \\
\hline K.C. & 25,9 & 26 & 25,5 & 0,1 & $-0,5$ \\
\hline L. F. & 33,6 & 37,8 & 36,3 & 4,2 & $-1,5$ \\
\hline M. S. R. & 25,5 & 31,8 & 32,1 & 6,3 & 0,3 \\
\hline M. R.F. & 29,5 & 31,1 & 32,2 & 1,6 & 1,1 \\
\hline M. P. & 26 & 27,9 & 28,7 & 1,9 & 0,8 \\
\hline M. S. G. & 30,9 & 33,1 & 33,9 & 2,2 & 0,8 \\
\hline M. A. & 26,4 & 28,1 & 30 & 1,7 & 1,9 \\
\hline M. C. & 25,8 & 25,6 & 28,9 & $-0,2$ & 3,3 \\
\hline M. A. & 19,3 & 30,7 & 29,8 & 11,4 & $-0,9$ \\
\hline M. C. & 22,7 & 26,6 & 28,3 & 3,9 & 1,7 \\
\hline M. A. G. & 30,7 & 29,8 & 30,1 & $-0,9$ & 0,3 \\
\hline N. M. & 28,5 & 31,3 & 32,3 & 2,8 & 1 \\
\hline R. M. & 28,3 & 28,7 & 28,5 & 0,4 & $-0,2$ \\
\hline R. J.L.G. & 30,5 & 32,1 & 33,2 & 1,6 & 1,1 \\
\hline R. W. & 26,9 & 29,3 & 31,3 & 2,4 & 2 \\
\hline S. M. & 25,8 & 29,1 & 28,4 & 3,3 & $-0,7$ \\
\hline S. F. C. & 31,4 & 32,5 & 33,4 & 1,1 & 0,9 \\
\hline T. G. S. & 28,5 & 31,3 & 32,6 & 2,8 & 1,3 \\
\hline V. G. & 28,3 & 32,3 & 33,6 & 4 & 1,3 \\
\hline
\end{tabular}




\section{0-Medida-AFAT}

\begin{tabular}{|c|c|c|c|c|c|}
\hline Pacientes & AFAT t1 & AFAT t2 & AFAT $\mathrm{t} 3$ & AFAT 2-1 & AFAT 3-2 \\
\hline A.F.S. & 110,9 & 112,6 & 115,1 & 1,7 & 2,5 \\
\hline A.S. & 109,3 & 113,6 & 110,7 & 4,3 & $-2,9$ \\
\hline A.A. M. & 111 & 111,4 & 118,4 & 0,4 & 7 \\
\hline A. R. Jr. & 115,3 & 118,2 & 128,6 & 2,9 & 10,4 \\
\hline A.A. Jr. & 126,4 & 132,7 & 132,4 & 6,3 & $-0,3$ \\
\hline C. C. 0. & 114 & 113,8 & 119,4 & $-0,2$ & 5,6 \\
\hline C. M.R. & 114,5 & 114,8 & 115 & 0,3 & 0,2 \\
\hline D. S. M. & 121,4 & 124,7 & 126,2 & 3,3 & 1,5 \\
\hline E.D.P.F.P. & 110,9 & 111,5 & 111,2 & 0,6 & $-0,3$ \\
\hline F. C. & 109,8 & 113,8 & 112,9 & 4 & $-0,9$ \\
\hline J.R. T. & 125,8 & 130 & 130,4 & 4,2 & 0,4 \\
\hline J. C.A.O. & 114,3 & 115,3 & 115 & 1 & $-0,3$ \\
\hline K.C. & 97,8 & 101,2 & 101,9 & 3,4 & 0,7 \\
\hline L. $F$. & 121,5 & 131 & 123,2 & 9,5 & 1,4 \\
\hline M. S. R. & 118,8 & 125,5 & 127,1 & 6,7 & 1,6 \\
\hline M. R.F. & 122,2 & 124,8 & 122,7 & 2,6 & $-2,1$ \\
\hline M. P. & 110,4 & 113,1 & 113,7 & 2,7 & 0,6 \\
\hline M. S. G. & 117 & 123,7 & 123,9 & 6,7 & 0,2 \\
\hline M. A. & 107,7 & 114 & 118,4 & 6,3 & 4,4 \\
\hline M. C. & 112,3 & 115,4 & 117,2 & 3,1 & 1,8 \\
\hline M. A. & 109,9 & 120,1 & 120,4 & 10,2 & 0,3 \\
\hline M. C. & 100,5 & 106,2 & 115,1 & 5,7 & 8,9 \\
\hline M. A. G. & 117,6 & 117,9 & 118,2 & 0,3 & 0,3 \\
\hline N. M. & 110,5 & 115,7 & 117,3 & 5,2 & 1,6 \\
\hline R. M. & 123,9 & 122,8 & 122,2 & $-1,1$ & $-0,6$ \\
\hline R. J.L.G. & 114 & 122,4 & 127,9 & 8,4 & 5,5 \\
\hline R.W. & 113,1 & 120,4 & 122,1 & 7,3 & 1,7 \\
\hline S. M. & 110,5 & 115 & 115,9 & 4,5 & 0,9 \\
\hline S. F.C. & 122 & 118,6 & 123,2 & $-3,4$ & 4,6 \\
\hline T. G. S. & 116,5 & 123,4 & 127,2 & 6,9 & 3,8 \\
\hline V. G. & 121,9 & 123,9 & 127,8 & 2 & 3,9 \\
\hline
\end{tabular}


21 Medida-BII-GoMe

\begin{tabular}{|c|c|c|c|c|c|}
\hline Pacientes & Bll-GoMe t1 & Bll-GoMe t2 & Bll-GoMe t3 & Bll- GoMe 2-1 & Bll- GoMe 3-2 \\
\hline A.F.S. & 35,2 & 36,4 & 39,9 & 1,2 & 3,5 \\
\hline A.S. & 37,4 & 39,4 & 38,2 & 2 & $-1,2$ \\
\hline A.A. M. & 38,7 & 37,9 & 40,6 & $-0,8$ & 2,7 \\
\hline A. R. Jr. & 39,3 & 41,2 & 44,4 & 1,9 & 3,2 \\
\hline A.A. Jr. & 40,8 & 43,2 & 44,9 & 2,4 & 1,7 \\
\hline C. C. 0. & 36,7 & 38,7 & 39,9 & 2 & 1,2 \\
\hline C. M.R. & 38,9 & 39,7 & 40,2 & 0,8 & 0,5 \\
\hline D. S. M. & 41,2 & 45,3 & 44,3 & 4,1 & -1 \\
\hline E.D.P.F. P. & 38,1 & 37,6 & 37,7 & $-0,5$ & 0,1 \\
\hline F. C. & 35,3 & 38,7 & 38,3 & 3,4 & $-0,4$ \\
\hline J.R. T. & 45,6 & 45 & 45,9 & $-0,6$ & 0,9 \\
\hline J. C.A.O. & 37,9 & 41,2 & 40,9 & 3,3 & $-0,3$ \\
\hline K.C. & 34,5 & 35,6 & 35,5 & 1,1 & $-0,1$ \\
\hline L. $F$. & 39,8 & 43,3 & 40,9 & 3,5 & $-2,4$ \\
\hline M. S. R. & 38,8 & 42,8 & 42,4 & 4 & $-0,4$ \\
\hline M. R.F. & 42,4 & 44,2 & 44,5 & 1,8 & 0,3 \\
\hline M. P. & 35,2 & 36,4 & 36,3 & 1,2 & $-0,1$ \\
\hline M. S. G. & 37,6 & 39,6 & 39,7 & 2 & 0,1 \\
\hline M. A. & 37,8 & 40,3 & 40,7 & 2,5 & 0,4 \\
\hline M. C. & 37,6 & 38,3 & 39,2 & 0,7 & 0,9 \\
\hline M. A. & 35,4 & 40,2 & 40,4 & 4,8 & 0,2 \\
\hline M. C. & 34,9 & 36,3 & 38,8 & 1,4 & 2,5 \\
\hline M. A. G. & 42,9 & 42 & 41,6 & $-0,9$ & $-0,4$ \\
\hline N. M. & 38,1 & 39,8 & 40 & 1,7 & 0,2 \\
\hline R. M. & 40,9 & 41,9 & 41,3 & 1 & $-0,6$ \\
\hline R. J.L.G. & 37,8 & 40,8 & 42,7 & 3 & 1,9 \\
\hline R. W. & 38,2 & 40,1 & 41,8 & 1,9 & 1,7 \\
\hline S. M. & 34,5 & 38 & 37,3 & 3,5 & $-0,7$ \\
\hline S. F.C. & 38,8 & 38,9 & 38,7 & 0,1 & $-0,2$ \\
\hline T. G. S. & 39,5 & 40,2 & 41,8 & 0,7 & 1,6 \\
\hline V. G. & 42,8 & 41,7 & 44,4 & $-1,1$ & 2,7 \\
\hline
\end{tabular}




\section{2-Medida AFAI}

\begin{tabular}{c|c|c|c|c|c} 
Pacientes & AFAI t1 & AFAI t2 & AFAI t3 & AFAI 2-1 & AFAI $3-2$ \\
\hline A.F.S. & 66,5 & 68,1 & 64,8 & 1,6 & $-3,3$ \\
\hline A.S. & 66 & 66,9 & 66,5 & 0,9 & $-0,4$ \\
\hline A.A. M. & 67,5 & 67,2 & 70,7 & $-0,3$ & 3,5 \\
\hline A. R. Jr. & 66 & 69,4 & 74,7 & 3,4 & 5,3 \\
\hline A.A. Jr. & 76,9 & 81,8 & 83 & 4,9 & 1,2 \\
\hline C. C. O. & 71,7 & 72,1 & 74,5 & 0,4 & 2,4 \\
\hline C. M.R. & 63,6 & 65,1 & 64,8 & 1,5 & $-0,3$ \\
\hline D. S. M. & 75 & 76,4 & 76,1 & 1,4 & $-0,3$ \\
\hline E.D.P.F. P. & 66,9 & 68,3 & 66,4 & 1,4 & $-1,9$ \\
\hline F. C. & 67,4 & 65,4 & 66,9 & -2 & 1,5 \\
\hline J. R. T. & 77,6 & 79,7 & 79,8 & 2,1 & 0,1 \\
\hline J. C.A.O. & 67,4 & 68,5 & 67,5 & 1,1 & -1 \\
\hline K.C. & 61 & 61,4 & 58,7 & 0,4 & $-2,7$ \\
\hline L. F. & 76,4 & 83,3 & 77,3 & 6,9 & -6 \\
\hline M. S. R. & 70,6 & 75,2 & 77,9 & 4,6 & 2,7 \\
\hline M. R.F. & 73,7 & 75,3 & 76,2 & 1,6 & 0,9 \\
\hline M. P. & 66,8 & 67,6 & 68,8 & 0,8 & 1,2 \\
\hline M. S. G. & 71,6 & 75 & 76 & 3,4 & 1 \\
\hline M. A. & 67,9 & 68,5 & 70,8 & 0,6 & 2,3 \\
\hline M. C. & 65,5 & 65,7 & 67,2 & 0,2 & 1,5 \\
\hline M. A. & 56,3 & 71,6 & 72,2 & 15,3 & 0,6 \\
\hline M. C. & 60,5 & 62,1 & 67,5 & 1,6 & 5,4 \\
\hline M. A. G. & 73,5 & 72 & 71,6 & $-1,5$ & $-0,4$ \\
\hline N. M. & 68 & 72,6 & 74,4 & 4,6 & 1,8 \\
\hline R. M. & 75,2 & 73,4 & 72,8 & $-1,8$ & $-0,6$ \\
\hline R. J.L.G. & 70,2 & 74,8 & 78,9 & 4,6 & 4,1 \\
\hline R. W. & 67,8 & 71,5 & 72,5 & 3,7 & 1 \\
\hline S. M. & 63 & 68,3 & 68,9 & 5,3 & 0,6 \\
\hline S. F. C. & 73,7 & 72,7 & 72,7 & -1 & 0 \\
\hline T. G. S. & 71,9 & 75,6 & 77,8 & 3,7 & 2,2 \\
\hline V. G. & 75,5 & 77,7 & 78,1 & 2,2 & 0,4 \\
\hline
\end{tabular}


23 Medida -BIS-PO

\begin{tabular}{|c|c|c|c|c|c|}
\hline Pacientes & BIS-PO t1 & BIS-PO t2 & BIS-PO t 3 & BIS-PO2-1 & BIS-PO3-2 \\
\hline A.F.S. & $-1,4$ & 1,8 & 2,8 & 3,2 & 1 \\
\hline A.S. & $-1,5$ & 2,1 & 2 & 3,6 & $-0,1$ \\
\hline A.A. M. & -4 & 0,6 & 1 & 4,6 & 0,4 \\
\hline A. R. Jr. & $-2,7$ & $-0,1$ & 2 & 2,6 & 2,1 \\
\hline A.A. Jr. & $-2,1$ & 1,1 & $-0,5$ & 3,2 & $-1,6$ \\
\hline C. C. 0 . & $-7,7$ & 1,5 & $-1,7$ & 9,2 & $-3,2$ \\
\hline C. M.R. & -2 & 3,2 & 3,1 & 5,2 & $-0,1$ \\
\hline D. S. M. & $-3,5$ & 1,8 & $-0,1$ & 5,3 & $-1,9$ \\
\hline E.D.P.F.P. & $-2,1$ & $-0,1$ & 0,2 & 2 & 0,3 \\
\hline F. C. & $-8,4$ & $-1,2$ & $-2,6$ & 7,2 & $-1,4$ \\
\hline J.R. T. & $-1,4$ & 2,3 & 3,2 & 3,7 & 0,9 \\
\hline J. C.A.O. & $-3,6$ & 1,6 & 1,5 & 5,2 & $-0,1$ \\
\hline K.C. & -1 & $-0,1$ & 0,9 & 0,9 & 1 \\
\hline L. F. & $-2,2$ & 1,6 & 2,1 & 3,8 & 0,5 \\
\hline M. S. R. & $-6,3$ & 1,6 & $-0,1$ & 7,9 & $-1,7$ \\
\hline M. R.F. & $-1,9$ & $-0,6$ & 1 & 1,3 & 1,6 \\
\hline M. P. & $-2,2$ & 0,7 & 1,3 & 2,9 & 0,6 \\
\hline M. S. G. & $-2,5$ & $-0,3$ & 0,8 & 2,2 & 1,1 \\
\hline M. A. & -2 & 1,8 & 2,9 & 3,8 & 1,1 \\
\hline M. C. & $-1,5$ & 0,7 & 1,6 & 2,2 & 0,9 \\
\hline M. A. & $-3,1$ & 0,4 & $-1,6$ & 3,5 & -2 \\
\hline M. C. & $-3,6$ & 2,2 & 0,7 & 5,8 & $-1,5$ \\
\hline M. A. G. & $-1,4$ & 0,5 & 2,9 & 1,9 & 2,4 \\
\hline N. M. & $-2,3$ & 0,8 & 0,5 & 3,1 & $-0,3$ \\
\hline R. M. & $-4,2$ & 1,7 & 0,3 & 5,9 & $-1,4$ \\
\hline R. J.L.G. & $-1,5$ & 1 & $-0,4$ & 2,5 & $-1,4$ \\
\hline R. W. & $-2,3$ & 0,9 & 1,8 & 3,2 & 0,9 \\
\hline S. M. & $-1,6$ & 1,2 & $-0,3$ & 2,8 & $-1,5$ \\
\hline S. F.C. & $-1,8$ & 2,4 & 1,3 & 4,2 & $-1,1$ \\
\hline T. G. S. & $-2,3$ & $-0,9$ & 0,1 & 1,4 & 1 \\
\hline V. G. & $-0,8$ & 1,7 & 5,1 & 2,5 & 3,4 \\
\hline
\end{tabular}


Tabela das Idades e médias totais das fases T1,T2 eT3

\begin{tabular}{|c|c|c|c|}
\hline Pacientes & idade t1 (a/ a.m.) & idade t2 (a/ a.m.) & idade $\mathrm{t} 3$ (a/ a.m.) \\
\hline A.F.S. & $14,16 a / 14 a 2 m$ & $16,58 a / 16 a 7 m$ & $31,33 a / 31 a 4 m$ \\
\hline A.S. & $15,85 a / 15 a 10$ & 18,83a / 18a10m & $30,58 a$ / 30a7m \\
\hline A.A. M. & $10,08 \mathrm{a} / 10 \mathrm{a} 1 \mathrm{~m}$ & $12,33 a / 12 a 4 m$ & $28,16 a / 28 a$ 2m \\
\hline A. R. Jr. & $11,25 a / 11 a 3 m$ & 13,5a / 13a6m & $18,66 \mathrm{a} / 18 \mathrm{a} 8 \mathrm{~m}$ \\
\hline A.A. Jr. & 13,66a / 13a8m & $15,66 a / 15 a 8 m$ & 20,41a / 20a5m \\
\hline C. C. 0 . & $11,08 / 11 \mathrm{a} 1 \mathrm{~m}$ & $12,58 \mathrm{a} / 12 \mathrm{a} 7 \mathrm{~m}$ & $17,83 a / 17 a 10$ \\
\hline C. M.R. & $15,16 a / 15 a 2 m$ & 17,83a / 17a10m & $33,08 a$ / 33a1m \\
\hline D. S. M. & $15,25 a / 15 a 3 m$ & $17 \mathrm{a} / 17 \mathrm{a} 0 \mathrm{~m}$ & $28,83 a / 28 a 10 m$ \\
\hline E.D.P.F. P. & $14,75 a / 14 a 9 m$ & 18,66a / 18a8m & $23,58 a / 23 a 7 m$ \\
\hline F.C. & 11,91a/11a11m & $16,16 a / 16 a 2 m$ & 20,91a / 20a11m \\
\hline J. R. T. & $14,83 a / 14 a 10 m$ & $16,91 \mathrm{a} / 16 \mathrm{a} 11 \mathrm{~m}$ & $22,16 a / 22 a 2 m$ \\
\hline J. C.A.O. & 13,33a / 13a4m & $15,33 a / 15 a 4 m$ & 20,91a / 20a11m \\
\hline K.C. & $11,25 a / 11 a 3 m$ & $13,41 \mathrm{a} / 13 \mathrm{a} 5 \mathrm{~m}$ & $18,08 \mathrm{a} / 18 \mathrm{a} 1 \mathrm{~m}$ \\
\hline L. F. & $16,33 a / 16 a 4 m$ & $18,58 a / 18 a 7 m$ & $24 a / 24 a 0 m$ \\
\hline M. S. R. & $16,25 a / 16 a 3 m$ & $18,41 \mathrm{a} / 18 \mathrm{a} 5 \mathrm{~m}$ & 23,66a / 23a8m \\
\hline M. R.F. & $14,66 a / 14 a 8 m$ & $16,5 a / 16 a 6 m$ & 21,91a/21a11m \\
\hline M. P. & $16,5 a / 16 a 6 m$ & 18,66a / 18a8m & $37,75 a / 37 a 9 m$ \\
\hline M. S. G. & 11,41a / 11a5m & $14,5 a / 14 a 6 m$ & $27,83 a / 27 a 10 m$ \\
\hline M. A. & 13,75a / 13a9m & $15,33 a / 15 a 4 m$ & $39 \mathrm{a} / 39 \mathrm{a} 0 \mathrm{~m}$ \\
\hline M. C. & 12,83a / 12a10m & $14,33 a / 14 a 4 m$ & $19,41 \mathrm{a} / 19 \mathrm{a} 5 \mathrm{~m}$ \\
\hline M. A. & $11,08 a / 11 a 1 m$ & $12,08 a / 12 a 1 m$ & $20,5 a / 20 a 6 m$ \\
\hline M. C. & $10,08 / 10 a 1 m$ & $12,25 a / 12 a 3 m$ & 18,83a / 18a10m \\
\hline M. A. G. & $15,33 a / 15 a 4 m$ & 17,83a / 17a10m & $32,75 a / 32 a 9 m$ \\
\hline N. M. & $10,33 / 10 a 4 m$ & $12,08 \mathrm{a} / 12 \mathrm{a} 1 \mathrm{~m}$ & $17 a / 17 a$ \\
\hline R. M. & 12,83a / 12a10m & $15,58 \mathrm{a} / 15 \mathrm{a} 7 \mathrm{~m}$ & $20,83 a / 20 a 10 m$ \\
\hline R. J.L.G. & 13,33a / 13a4m & $15,66 a / 15 a 8 m$ & $20,16 a / 20 a 2 m$ \\
\hline R. W. & $11,75 a / 11 a 9 m$ & 13,5a / 13a6m & 18,83a / 18a10m \\
\hline S. M. & $12,75 a / 12 a 9 m$ & 14,91a/14a11m & $20,58 a / 20 a 7 m$ \\
\hline S. F.C. & 15,75a / 15a9m & $18,41 \mathrm{a} / 18 \mathrm{a} 5 \mathrm{~m}$ & $24,25 a / 24 a 3 m$ \\
\hline T. G. S. & $12,25 a / 12 a 3 m$ & $15,58 \mathrm{a} / 15 \mathrm{a} 7 \mathrm{~m}$ & $21,25 a / 21 a 3 m$ \\
\hline V. G. & $14,33 a / 14 a 4 m$ & $17,25 a / 17 a 3 m$ & $22,16 a / 22 a 2 m$ \\
\hline Média & $13,22 a$ & $15,68 a$ & $24,03 a$ \\
\hline
\end{tabular}

